\title{
CHARACTERIZATION OF SELECTED RADIONUCLIDES IN SEDIMENT AND SURFACE WATER IN STANDLEY LAKE, GREAT WESTERN RESERVOIR, AND MOWER RESERVOIR, JEFFERSON COUNTY, COLORADO, 1992
}

by David W. Clow and David A. Johncox

U.S. GEOLOGICAL SURVEY

Water-Resources Investigations Report 95-4126

Prepared in cooperation with the U.S. DEPARTMENT OF ENERGY

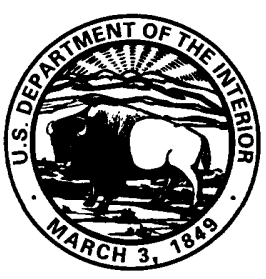




\section{U.S. DEPARTMENT OF THE INTERIOR \\ BRUCE BABBITT, Secretary}

U.S. GEOLOGICAL SURVEY

Gordon P. Eaton, Director

The use of trade, product, industry, or firm names is for descriptive purposes only and does not imply endorsement by the U.S. Government.

For additional information write to:

Copies of this report can be purchased from:

District Chief

U.S. Geological Survey

Box 25046, MS 415

Denver Federal Center

Denver, CO 80225
U.S. Geological Survey

Earth Science Information Center

Open-File Reports Section

Box 25286, MS 517

Denver Federal Center

Denver, CO 80225 


\section{CONTENTS}

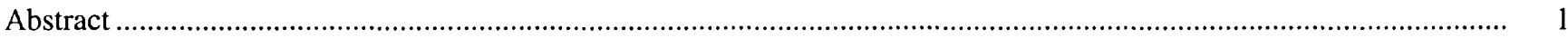

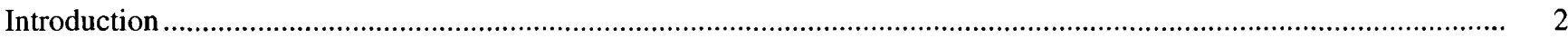

Purpose and scope

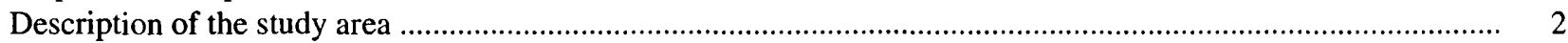

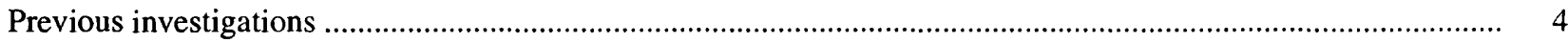

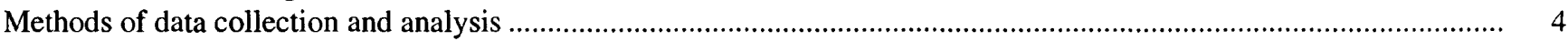

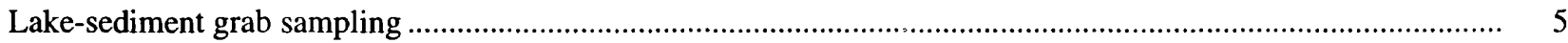

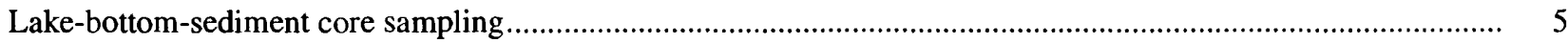

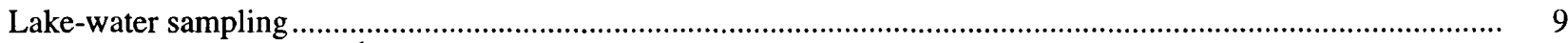

Quality-assurance procedures and analytical methods ................................................................................... 10

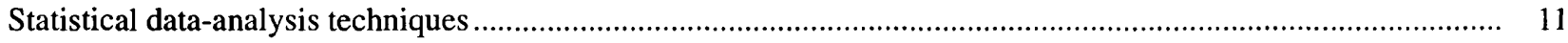

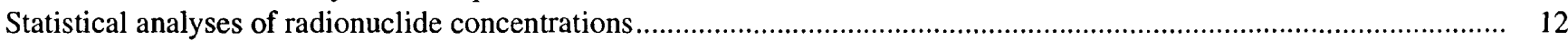

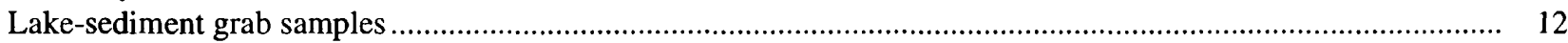

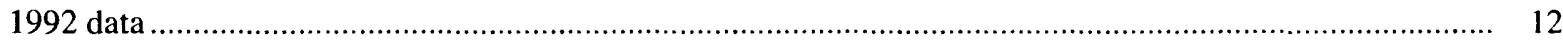

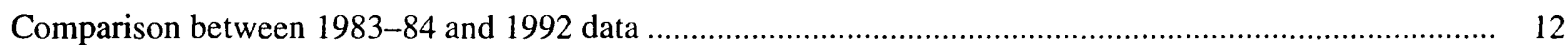

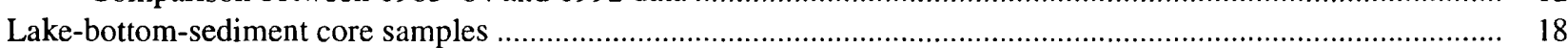

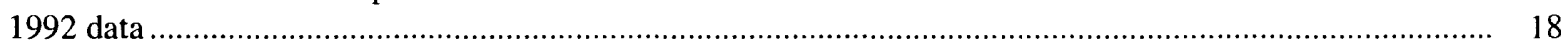

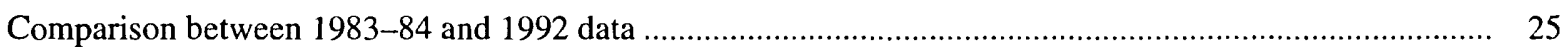

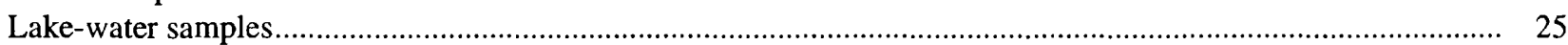

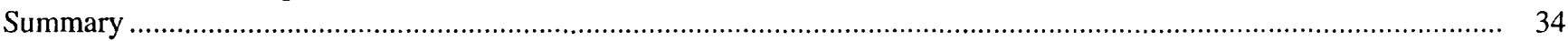

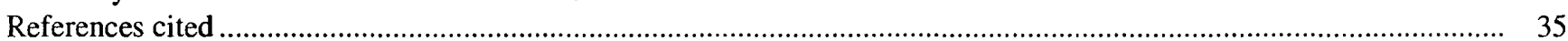

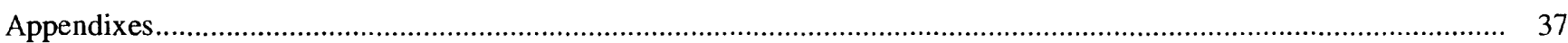

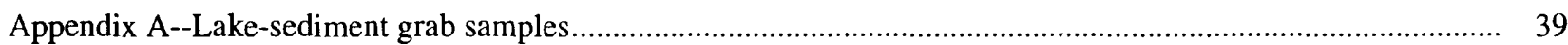

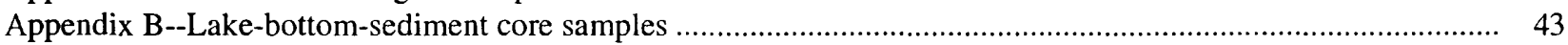

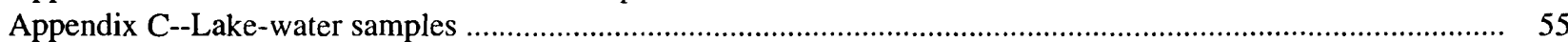

\section{FIGURES}

1-4. Maps showing location of:

1. Standley Lake, Great Western Reservoir, Mower Reservoir, and surrounding area ............................... 3

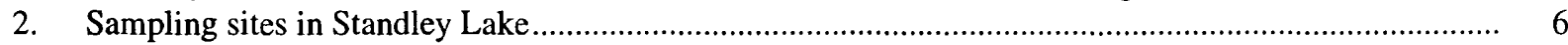

3. Sampling sites in Great Western Reservoir ................................................................................ 7

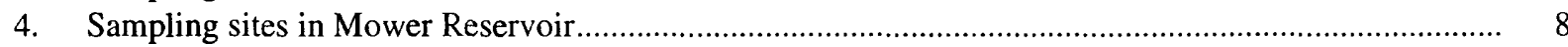

5. Map showing concentrations of ${ }^{239,240} \mathrm{Pu}$ in lake-sediment grab samples collected from Standley Lake, Great Western Reservoir, and Mower Reservoir

6. Boxplots showing distribution of ${ }^{239,240} \mathrm{Pu}$ concentrations in lake-sediment grab samples collected from Standley Lake, Great Western Reservoir, and Mower Reservoir

7. Map showing concentrations of ${ }^{241} \mathrm{Am}$ in lake-sediment grab samples collected from Standley Lake, Great Western Reservoir, and Mower Reservoir.

8. Boxplots showing distribution of ${ }^{241} \mathrm{Am}$ concentrations in lake-sediment grab samples collected from Standley Lake, Great Western Reservoir, and Mower Reservoir..

9A-B. Boxplots showing:

9A. Distribution of ${ }^{239,240} \mathrm{Pu}$ concentrations in $1983-84$ and 1992 and differences between matched pairs of lake-sediment grab samples at Standley Lake

9B. Distribution of ${ }^{239,240} \mathrm{Pu}$ concentrations in 1983-84 and 1992 and differences between matched pairs of lake-sediment grab samples at Great Western Reservoir. 
10-13. Graphs showing:

10. Relation between ${ }^{239,240} \mathrm{Pu}$ concentrations in lake-sediment grab samples collected at co-located sites in 1983-84 and in 1992 at Standley Lake

11. Relation between ${ }^{239.240} \mathrm{Pu}$ concentrations in lake-sediment grab samples collected at co-located sites in 1983-84 and in 1992 at Great Western Reservoir

12. Concentrations of ${ }^{239,240} \mathrm{Pu}$ and ${ }^{241} \mathrm{Am}$ in lake-bottom-sediment core SED08392 collected from Standley Lake

13. Ratio of concentrations of ${ }^{241} \mathrm{Am}$ to ${ }^{239,240} \mathrm{Pu}$ in lake-bottom-sediment core SED08392 collected from Standley Lake.

14A-14B. Scatterplots showing:

14A. Relation between ${ }^{241} \mathrm{Am}$ to ${ }^{239,240} \mathrm{Pu}$ concentration ratio and ${ }^{239,240} \mathrm{Pu}$ concentration in lake-bottom-sediment core samples collected from Standley Lake and Great Western Reservoir

14B. Relation between concentrations of ${ }^{239,240} \mathrm{Pu}$ and ${ }^{241} \mathrm{Am}$ in lake-bottom-sediment core samples collected from Standley Lake and Great Western Reservoir

$15 \mathrm{~A}-15 \mathrm{D}$. Graphs showing relation of concentrations of ${ }^{239,240} \mathrm{Pu}$ to depth at lake-bottom-sediment site:

15A. SED08192 collected from Standley Lake in 1983-84 and 1992

15B. SED08392 collected from Standley Lake in 1983-84 and 1992

15C. SED09192 collected from Great Western Reservoir in 1983-84 and 1992

15D. SED08592 collected from Great Western Reservoir in 1983-84 and 1992

16A. Boxplot showing distribution of concentrations of ${ }^{239,240} \mathrm{Pu}$ in lake-bottom-sediment core samples collected from Standley Lake and Great Western Reservoir

16B. Scatterplot showing relation between ${ }^{239,240} \mathrm{Pu}$ concentrations in lake-bottom-sediment core samples collected from Standley Lake and Great Western Reservoir in 1983-84 and 1992

17. Map showing gross alpha concentrations in water samples collected in 1992 from Standley Lake, Great Western Reservoir, and Mower Reservoir

18. Boxplot showing distribution of gross alpha concentrations in water samples collected in 1992 at Standley Lake, Great Western Reservoir, and Mower Reservoir

\section{TABLES}

1. Summary statistics for radionuclide concentrations in duplicate samples.

2. Summary statistics for radionuclide concentrations in equipment rinsates

3. Summary statistics for radionuclide concentrations in lake-sediment grab samples

4. Radionuclide concentrations in lake-bottom-sediment core samples.

5. Summary statistics for radionuclide concentrations in lake-water samples.

A1. Radionuclide concentrations in lake-sediment grab samples

A2. Chemical concentrations in lake-sediment grab samples

Appendix B-Lake-bottom-sediment core samples

B1. Lake-bottom-sediment core descriptions

B2. Chemical concentrations in lake-bottom-sediment core samples

Appendix C-Surface-water samples

$\mathrm{Cl}$. Field measurements at lake-water-sampling sites

C2. Radionuclide concentrations in lake-water samples

C3. Chemical concentrations in lake-water samples. 


\begin{tabular}{rll}
\hline Multiply & \multicolumn{1}{c}{ By } & To obtain \\
acre & & \\
acre-foot (acre-ft) & 0.004047 & square kilometer \\
centimeter $(\mathrm{cm})$ & $1,233.49$ & cubic meter \\
foot $(\mathrm{ft})$ & 0.3937 & meter \\
inch $(\mathrm{in})$ & 0.3048 & millimeter \\
liter $(\mathrm{L})$ & 25.4 & gallon (US) \\
inch \\
micrometer $(\mu \mathrm{m})$ & 0.2642 & ounce \\
milliliter $(\mathrm{mL})$ & 0.00003937 & kilometer \\
mile $(\mathrm{mi})$ & 0.03381 & square kilometer \\
\hline
\end{tabular}

Degree Celsius $\left({ }^{\circ} \mathrm{C}\right)$ may be converted to degree Fahrenheit $\left({ }^{\circ} \mathrm{F}\right)$ by using the following equation:

$$
{ }^{\circ} \mathrm{F}=9 / 5\left({ }^{\circ} \mathrm{C}\right)+32 \text {. }
$$

The following terms and abbreviations also are used in the report:

microgram per liter $(\mu \mathrm{g} / \mathrm{L})$

microsiemens per centimeter at 25 degrees Celsius $(\mu \mathrm{S} / \mathrm{cm})$

milligram per kilogram $(\mathrm{mg} / \mathrm{kg})$

milligram per liter $(\mathrm{mg} / \mathrm{L})$

nanocurie per square meter $\left(\mathrm{nCi} / \mathrm{m}^{2}\right)$

picocurie per gram $(\mathrm{pCi} / \mathrm{g})$

picocurie per liter $(\mathrm{pCi} / \mathrm{L})$

year (yr)

Sea level: In this report "sea level" refers to the National Geodetic Vertical Datum of 1929 (NGVD of 1929)--a geodetic datum derived from a general adjustment of the first-order level nets of both the United States and Canada, formerly called Sea Level Datum of 1929. 


\title{
Characterization of Selected Radionuclides in Sediment and Surface Water in Standley Lake, Great Western Reservoir, and Mower Reservoir, Jefferson County, Colorado, 1992
}

\author{
By David W. Clow and David A. Johncox
}

\section{Abstract}

Sediment and surface water from Standley Lake, Great Western Reservoir, and Mower Reservoir, near Denver, Colorado, were sampled and analyzed for selected radionuclides during August through October 1992. These reservoirs are located about 1.5 to 3.3 miles east of the U.S. Department of Energy's Rocky Flats Environmental Technology Site, formerly the Rocky Flats Plant, which was a manufacturing site for nuclear bomb triggers. In the 1960's, drums containing oil contaminated with plutonium leaked onto the ground. Some of these contaminated soils were subsequently dispersed offsite by wind. In 1983-84, plant operators sampled reservoir sediment from Standley Lake and Great Western Reservoir and determined that some sediment was contaminated with plutonium-239,240 $\left({ }^{239,240} \mathrm{Pu}\right)$. However, the data from the 1983-84 study lacked the quality-assurance criteria currently (1992) required by the Rocky Flats Field Office. In 1992, the U.S. Geological Survey, in cooperation with the U.S. Department of Energy, undertook a study to: (1) Characterize concentrations of selected radionuclides in lake sediment and surface water at Standley Lake, Great Western Reservoir, and Mower Reservoir; and (2) compare ${ }^{239,240} \mathrm{Pu}$ lake-sediment data obtained in 1983-84 to results from co-located lake-sediment samples obtained in 1992 by the U.S. Geological Survey.

Median ${ }^{239,240} \mathrm{Pu}$ concentrations in lakesediment grab samples from Standley Lake, Great Western Reservoir, and Mower Reservoir were
$0.037,0.105$, and 0.351 picocuries per gram $(\mathrm{pCi} / \mathrm{g})$, and the differences between the reservoirs were statistically significant at $p<0.05$. The highest ${ }^{239,240} \mathrm{Pu}$ concentrations were measured in lake-sediment grab samples collected from reservoirs closest to Rocky Flats Environmental Technology Site, which is consistent with the spatial pattern of ${ }^{239,240} \mathrm{Pu}$ concentrations identified in soil surrounding the site in previous studies.

The maximum concentration of ${ }^{239,240} \mathrm{Pu}$ dissolved in lake water was 0.009 picocuries per liter, well below limits suggested by the Colorado Department of Public Health and Environment. Dissolved gross alpha and uranium isotope concentrations were below National Drinking Water Standards in all water samples.

There was no statistically significant difference between ${ }^{239,240} \mathrm{Pu}$ concentrations in lakesediment grab samples collected from Standley Lake in 1983-84 and in 1992; however, there was a small, but statistically significant difference at Great Western Reservoir $(p<0.05)$. Mean ${ }^{239,240} \mathrm{Pu}$ concentrations at Great Western Reservoir were $0.140 \mathrm{pCi} / \mathrm{g}$ lower in 1992 , and median concentrations were $0.040 \mathrm{pCi} / \mathrm{g}$ lower. One possible explanation for the difference in concentrations in lake-bottom-sediment grab samples is that new sediments with relatively low ${ }^{239,240} \mathrm{Pu}$ concentrations may have buried older sediments containing higher concentrations of ${ }^{239,240} \mathrm{Pu}$; the grab-sampling technique collects only the top 2 to 4 inches of sediment from the lake bottom.

In lake-bottom-sediment cores, trends in ${ }^{239,240} \mathrm{Pu}$ concentrations with depth in 1992 were 
similar to trends identified in the 1983-84 study. Maximum ${ }^{239,240} \mathrm{Pu}$ concentrations occurred at depths ranging from 13 to 31 inches below the sediment-water interface at most sites. There was a small, but statistically significant $(\mathrm{p}<0.05)$ difference in ${ }^{239,240} \mathrm{Pu}$ concentrations in co-located lake-bottom-sediment cores collected in 1983-84 and in 1992. Measured concentrations tended to be higher in 1983-84 than in 1992. The median difference between data sets was $0.050 \mathrm{pCi} / \mathrm{g}$, and differences tended to increase with concentration; in samples with concentrations above $1.5 \mathrm{pCi} / \mathrm{L}$, concentrations were 10 to 30 percent higher in 1983-84 than in 1992. The differences in concentrations could be attributable to spatial variations in sediment and ${ }^{239,240} \mathrm{Pu}$ deposition.

\section{INTRODUCTION}

Standley Lake, Great Western Reservoir, and Mower Reservoir are man-made water bodies used for domestic water supply and irrigation in northeastern Jefferson County, Colorado (fig. 1). These reservoirs (hereinafter referred to as lakes) are located 1.5 to $3.3 \mathrm{mi}$ east of the Rocky Flats Environmental Technology Site (RFETS, formerly known as the Rocky Flats Plant), which is about 16 mi northwest of Denver, Colorado. The RFETS, which is owned by the U.S. Department of Energy (DOE) and operated by contractors, was built in 1951 and has been used for plutonium processing, purification, and machining in the manufacture of triggers for nuclear bombs. In the 1960 's, drums containing oil contaminated with plutonium leaked onto the ground at the 903 pad (fig. 1), and contaminated soil was subsequently transported offsite by wind erosion (Krey and Hardy, 1970). Investigations in the 1970's, 80's, and 90's indicated that soil near the RFETS was contaminated with plutonium$239,240\left({ }^{239,240} \mathrm{Pu}\right.$, which is plutonium- $239+$ plutonium-240) and americium-241 $\left({ }^{241} \mathrm{Am}\right)$, which is a daughter product of p!utonium-241 $\left({ }^{241} \mathrm{Pu}\right)(\mathrm{Krey}$ and Hardy, 1970; Hardy and others, 1980; Thomas and Robertson, 1981; Setlock, 1983; Setlock and Paricio, 1984; Litoar and others, 1994). In 1983-84, the RFETS contractor measured elevated levels of ${ }^{239,240} \mathrm{Pu}$ in bottom sediment from Standley Lake and Great Western Reservoir (Setlock, 1983; Setlock and Paricio, 1984). However, the data were not collected using the quality-assurance criteria currently required by the DOE-RFETS. Between August 27 and
Oct. 14, 1992, the U.S. Geological Survey (USGS), in cooperation with the DOE, collected lake-sediment grab samples, lake-bottom sediment cores, and water samples from Standley Lake, Great Western Reservoir, and Mower Reservoir.

\section{Purpose and Scope}

This report summarizes concentrations of selected radionuclides in sediment and water samples collected in 1992 from Standley Lake, Great Western Reservoir, and Mower Reservoir. The report also describes the results of comparisons between ${ }^{239,240} \mathrm{Pu}$ concentrations in sediment collected from Standley Lake and Great Western Reservoir in 1983-84 and 1992. Analytical results for radionuclide, trace element, major-element composition, and other selected water-quality constituents in individual sediment and water samples are presented in the appendixes at the back of this report.

\section{Description of the Study Area}

Standley Lake is a reservoir in the city of Westminster, a suburb of Denver, in northeastern Jefferson County and is about $3.3 \mathrm{mi}$ southeast of the RFETS (fig. 1). This lake is formed by an earthen dam on Big Dry Creek and originally was constructed in about 1910 to supply water for irrigation. Standley Lake supplies drinking water for the cities of Westminster, Thornton, and Northglenn, which are located $4 \mathrm{mi}$ southeast, $8 \mathrm{mi}$ east, and $7 \mathrm{mi}$ northeast of Standley Lake. About two-thirds of the lake water is municipal water supply, and the other one-third is for irrigation. The full capacity of the lake is about 43,000 acre- $\mathrm{ft}$; the mean depth is about $36 \mathrm{ft}$, and the maximum depth is $96 \mathrm{ft}$-based on the original land surface (Ruddy and others, 1992). Almost all the inflow to Standley Lake is delivered by canals flowing from the southeast which do not pass through the RFETS. Woman Creek, which drains the southern side of the RFETS, flows intermittently into Standley Lake. Standley Lake is owned and operated by the Farmers Reservoir and Irrigation Company of Brighton.

Great Western Reservoir is in northeastern Jefferson County about $1.5 \mathrm{mi}$ east of the RFETS (fig. 1). Great Western Reservoir has an earthen dam that was built in 1904 and originally was designed to supply water for irrigation. The lake is owned and operated by the city of Broomfield, which is located $2 \mathrm{mi}$ to the northeast of Great Western Reservoir and supplies drinking water to the city. The full capacity of the lake 


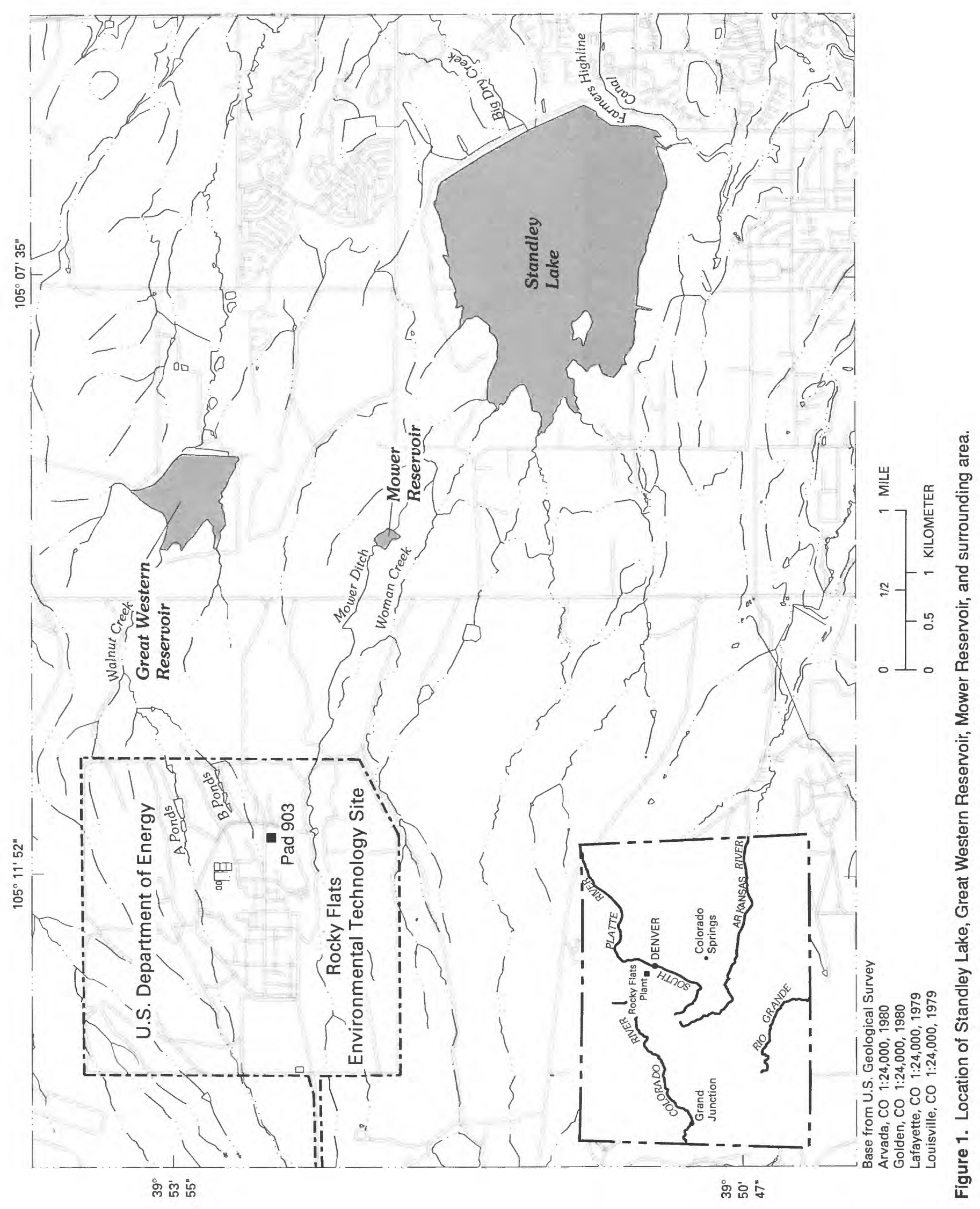


is about 3,250 acre-ft. Most of the inflow to Great Western Reservoir comes from a canal flowing from the southeast, which does not pass through the RFETS. Walnut Creek, which flows from the RFETS, previously flowed into Great Western Reservoir but, in 1992, was diverted around Great Western Reservoir (U.S. Department of Energy, 1992). Outflow from Great Western Reservoir is into Walnut Creek, which joins Big Dry Creek several miles downstream.

Mower Reservoir is a small, privately owned lake about $1.5 \mathrm{mi}$ southeast of the RFETS (fig. 1). Mower Reservoir water is used solely for agriculture. The lake covers an area of about 9 acres (U.S. Department of Energy, 1992). Inflow into Mower Reservoir is delivered from Mower Ditch, which diverts water from Woman Creek. Outflow discharges into Standley Lake southeast of Mower Reservoir. The lake had a maximum depth of about $5 \mathrm{ft}$ during the sampling period. A dense mat of aquatic weeds covers most of the lake throughout the growing season.

\section{Previous Investigations}

${ }^{239} \mathrm{Pu},{ }^{240} \mathrm{Pu}$, and ${ }^{241} \mathrm{Pu}$ are by-products of the nuclear processing activities that occurred at the RFETS. The half-life of ${ }^{239} \mathrm{Pu}$ is 24,100 years, the half-life of ${ }^{240} \mathrm{Pu}$ is 6,560 years, and the half-life of ${ }^{241} \mathrm{Pu}$ is 14.4 years (Walker and others, 1989). ${ }^{241} \mathrm{Am}$ is a decay product of ${ }^{241} \mathrm{Pu}$ and has a half-life of 432.7 years. ${ }^{239} \mathrm{Pu},{ }^{240} \mathrm{Pu}$, and ${ }^{241} \mathrm{Am}$ primarily are alpha emitters and are the most prevalent transuranic contaminants in the soil at the RFETS (Litoar and others, 1994). A summary of the results of previous soil and lake-sediment investigations in the vicinity of the RFETS is provided in the following paragraphs.

A study conducted in 1970 characterized ${ }^{239,240} \mathrm{Pu}$ concentrations in soil surrounding the RFETS, and a contamination pattern converging on the drum storage site was identified (Krey and Hardy, 1970). Concentrations of ${ }^{239,240} \mathrm{Pu}$ in soil at the storage site were more than $2,000 \mathrm{nCi} / \mathrm{m}^{2}$ and decreased in all directions away from the storage site (Krey and Hardy, 1970). These findings were confirmed by Litoar and others (1994), who measured ${ }^{239,240} \mathrm{Pu}$ and ${ }^{241} \mathrm{Am}$ concentrations as much as $4,440 \mathrm{pCi} / \mathrm{g}$ in soil near the drum storage site. It also was determined that 90 percent of ${ }^{239,240} \mathrm{Pu}$ and ${ }^{241} \mathrm{Am}$ concentrations were in the top $12 \mathrm{~cm}$ of soil, but earthworm burrowing probably was responsible for transporting some of the actinides to depths of $40 \mathrm{~cm}$ (Litoar and others, 1994).
In 1970 and 1973, the U.S. Environmental Protection Agency collected lake-bottom-sediment grab samples to determine ${ }^{239,240} \mathrm{Pu}$ levels in the sediment in Standley Lake. The concentrations were predominantly at background levels attributable to geologic and atmospheric testing sources of less than or equal to $0.10 \mathrm{pCi} / \mathrm{g}$ (U.S. Environmental Protection Agency, $1973,1975)$. Maximum ${ }^{239,240} \mathrm{Pu}$ levels were $0.37 \mathrm{pCi} / \mathrm{g}$ in the 1970 study and $0.17 \mathrm{pCi} / \mathrm{g}$ in the 1973 study.

Lake-bottom-sediment cores were collected in 1974 in Standley Lake and Great Western Reservoir by a DOE contractor, Battelle Laboratory. One core from Standley Lake had a maximum ${ }^{239,240} \mathrm{Pu}$ concentration of $0.39 \mathrm{pCi} / \mathrm{g}$, and a core from Great Western Reservoir had a maximum of $6.09 \mathrm{pCi} / \mathrm{g}$ (Thomas and Robertson, 1981).

In 1976, a lake-bottom-sediment core sample was collected from Standley Lake to determine the timing of plutonium releases (Hardy and others, 1980). Using a combination of actinides, the history of deposition of selected radionuclides was established, including fallout from nuclear bomb testing, nuclearpowered satellite failures, and releases at the RFETS. About 70 percent of the ${ }^{239,240} \mathrm{Pu}$ occurred in the uppermost $30 \mathrm{~cm}$ of the lake-bottom-sediment core, which Hardy and others (1980) attributed to drum leakage from the RFETS. The remaining 30 percent of the $239.240 \mathrm{Pu}$ was attributed to atmospheric fallout during extensive nuclear testing in the 1950's and early 1960's (Hardy and others, 1980).

Additional studies were conducted in 1983 and 1984 by the DOE contractor, Rockwell International, to improve the existing knowledge of environmental radionuclide concentrations and relevant transport phenomena in Standley Lake and Great Western Reservoir (Setlock, 1983; Setlock and Paricio, 1984). In each of these studies, lake-sediment grab samples and lakebottom-sediment cores were collected. Maximum $239,240 \mathrm{Pu}$ concentrations in lake-bottom-sediment cores from Standley Lake were $0.61 \mathrm{pCi} / \mathrm{g}$. Maximum ${ }^{239,240} \mathrm{Pu}$ concentrations in core samples from Great Western Reservoir were between 4.9 and $5.4 \mathrm{pCi} / \mathrm{g}$. The 1983 and 1984 studies are the focus of the historical data comparison contained in this report.

\section{METHODS OF DATA COLLECTION AND ANALYSIS}

Sample-collection methods were designed to determine physical and chemical characteristics of sediment and water in the three lakes. Methods used for sample collection followed the RFETS environmental 
management standard operating procedures (EG\&G, Rocky Flats, Inc., 1991) and are described or referenced in the following sections. The USGS boat was decontaminated at the RFETS decontamination pad according to standard procedures. Decontamination of the boat was done before and after the sampling of each lake. The samples were relinquished on the chain-ofcustody to the DOE subcontractor for handling and shipping to the contract laboratories. The DOE subcontractor provided the sample bottles, which met the quality-assurance/quality-control requirements (U.S. Department of Energy, 1994), the sample bottle labels, and the chain-of-custody sheets. Sampling and decontamination methods specific to each type of sampling are described in the following sections.

\section{Lake-Sediment Grab Sampling}

Lake-sediment grab samples were collected from predetermined locations in the lakes. Sampling locations correspond to sites sampled during the 1983-84 studies at the RFETS. Sixteen lake-sediment grab samples were collected from Standley Lake on Sept. 3-4, 1992 (fig. 2), 15 samples were collected at Great Western Reservoir on Aug. 27-28 and Sept. 2, 1992 (fig. 3), and 3 samples were collected from Mower Reservoir on Sept. 10, 1992 (fig. 4). The lake-sediment grab samples were analyzed for selected radionuclides (table A-1 in Appendix A at the back of this report), trace elements, major ions, and cyanide (table A-2 in Appendix A). Analyses for total organic carbon were done for 10 percent of all grab samples at selected sampling sites.

Lake-sediment grab samples were collected using an Eckman dredge. The required volume of sediment sampled at most of the sites was $750 \mathrm{~mL}$. Analyses for total organic carbon required an additional $1,250 \mathrm{~mL}$ of sediment for a total of about $2 \mathrm{~L}$. The volume of sediment collected by the dredge was dependent on the physical consistency of the sediment. Where the sediment was soft, about $2 \mathrm{~L}$ was collected. Sandy or gravelly bottoms yielded only about 0.16 to $0.66 \mathrm{~L}$ of sediment, and several grabs had to be made at these sites to achieve the $750 \mathrm{~mL}$. Once the dredge was retrieved, the sediment was emptied into a clean stainless-steel bowl and homogenized using a clean stainless-steel spoon. The sample then was containerized using the stainless-steel spoon to place the sediment in the sample bottle. Between samples, the decontamination of the dredge and the stainless-steel bowl and spoon consisted of a detergent wash, a deionized water rinse with a pressurized sprayer, and a drying with paper towels.

\section{Lake-Bottom-Sediment Core Sampling}

Lake-bottom-sediment core samples were collected from Standley Lake, Great Western Reservoir, and Mower Reservoir. Coring locations at Standley Lake and Great Western Reservoir in 1992 correspond to sites sampled during the 1983-84 studies. Lakebottom-sediment core samples had not been previously collected at Mower Reservoir, and the coring locations there were determined by the USGS. A core was collected near the dam structure of each lake, near the center of each lake somewhere near the original stream channel, and in the deltas where the main tributaries flow into each lake. Two separate lake-bottomsediment cores were collected at each sampling site: one core for chemical analyses, and the second for physical description.

Lake-bottom-sediment cores from the lakes were collected using a gravity-driven piston coring device (EG\&G Rocky Flats Inc., 1991). The coring equipment consisted of a galvanized-steel weight stand that had fins, an attached galvanized-steel core barrel, driving weights, galvanized couplings, polyvinyl chloride (PVC) finger assembly, hose clamps, 2.6-in-diameter polybutyrate core liners, and a PVC piston valve. Once fully assembled, the coring device was attached to a steel cable and lowered into the water using a USGS E-reel (Buchanan and Somers, 1980). The coring device was lowered to about $20 \mathrm{ft}$ from the lake bottom. At this point, the coring device was allowed to free-fall to the lake bottom to obtain a maximum core length. At the shallow sampling sites at Mower Reservoir, the coring device was allowed to free-fall from the water surface to get enough momentum to obtain an adequate core sample. The core sample was raised to the water surface using the E-reel. The core liner was removed from the core barrel, and end caps were secured on both ends of the liner. The liner was labeled and stored vertically in a cooled core-liner storage box.

The two core samples from each site were taken to a shore station for extrusion, description, and containerizing. Lake water above the sediment was siphoned from the core liner with a peristaltic pump, and an extrusion rod was placed in the bottom of the core liner. A clean 2 -in.-long cutting sleeve was placed on top of the core liner, and a 2-in. section of core was pushed up into the cutting sleeve. A polyethylene cutter was inserted between the top of the core liner and the bottom of the cutting sleeve, and a 2-in. sample was cut from the core. The sample was put into a sample bottle and homogenized using a clean plastic spatula. A subsample was collected from this bottle and placed into a second sample bottle. One sample bottle was for analysis of radionuclides, and the other sample bottle 


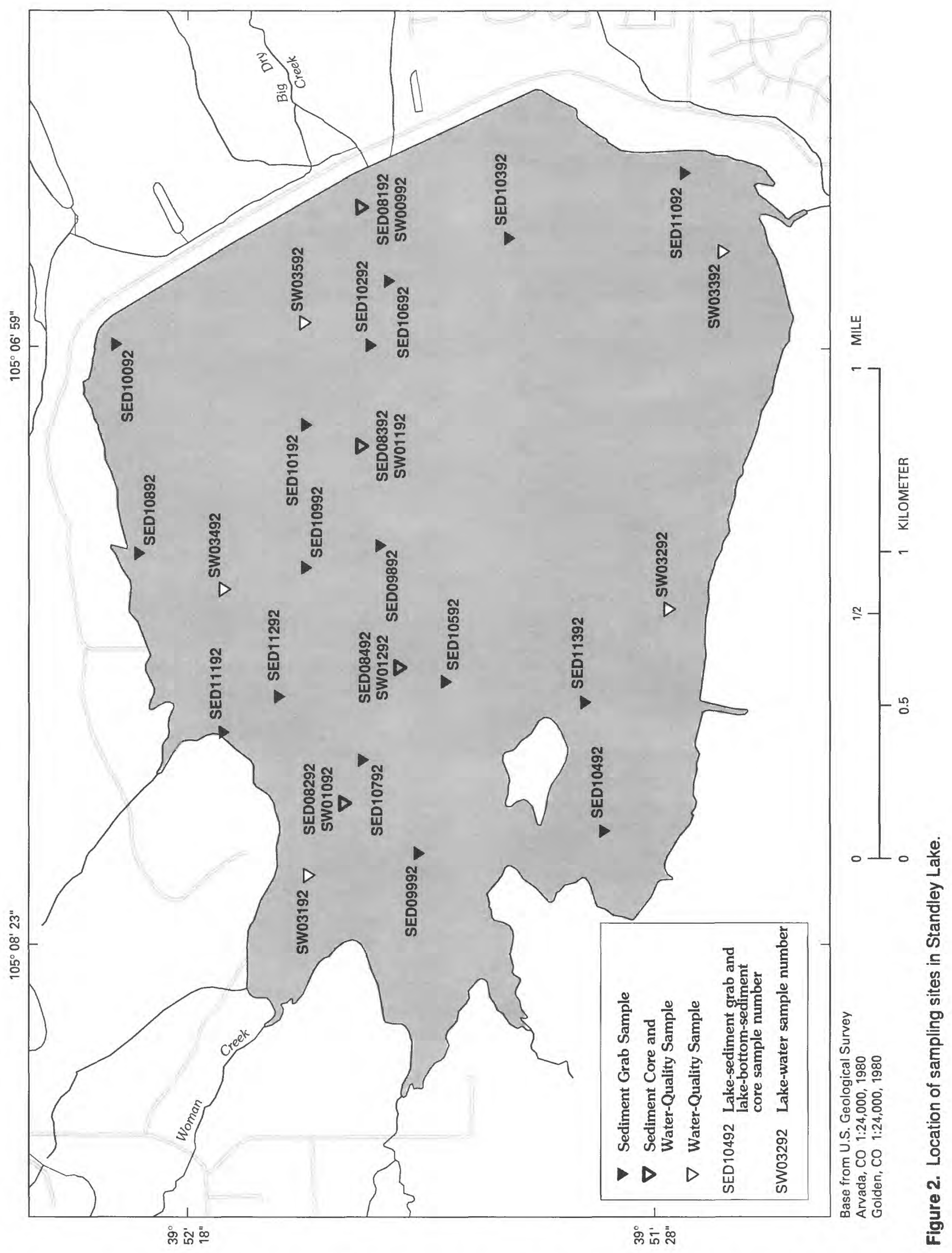

6 Characterization of Selected Radionuclides in Sediment and Surface Water in Standley Lake, Great Western Reservoir, and Mower Reservoir, Jefferson County, Colorado, 1992 


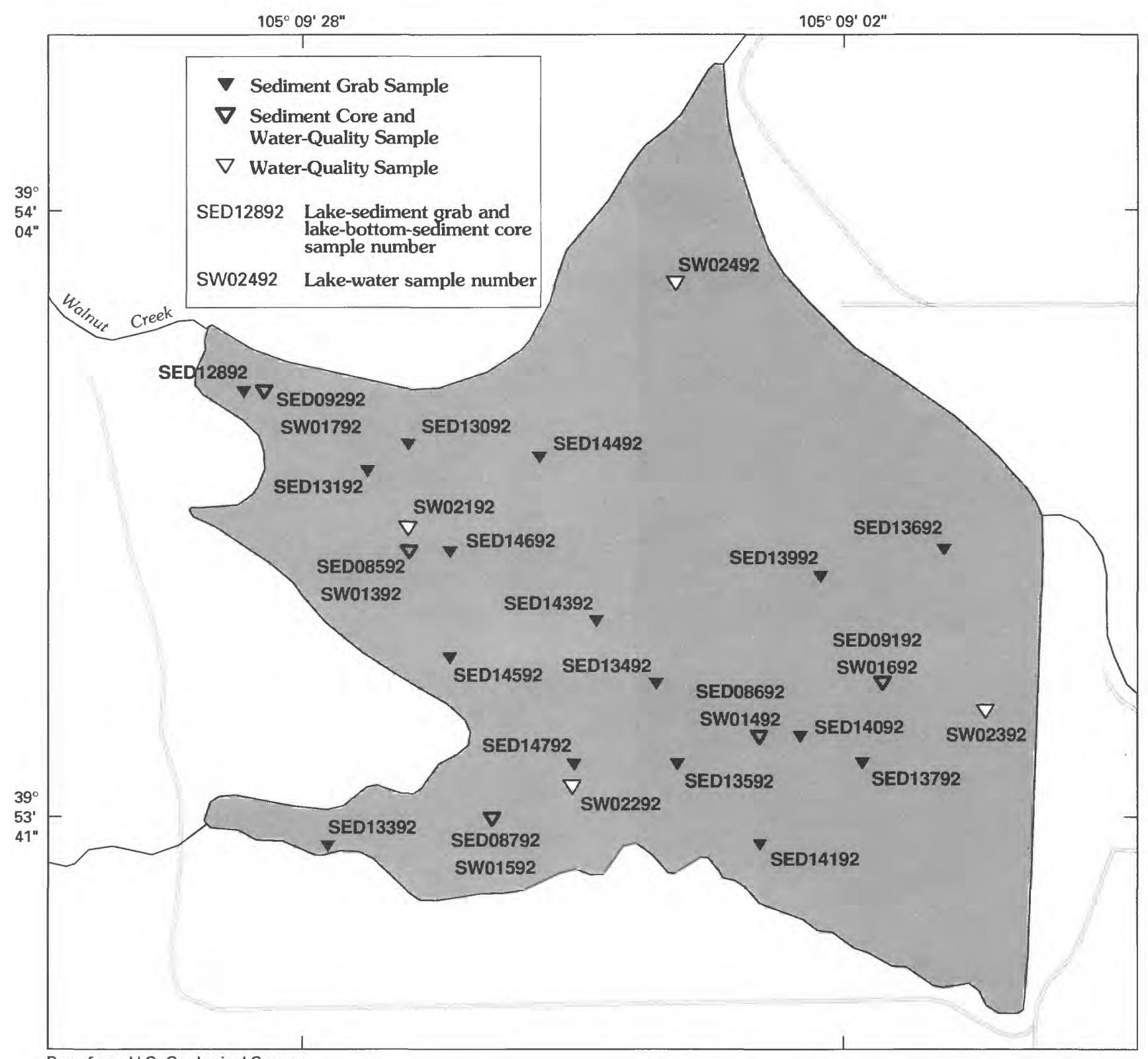

Base from U.S. Geological Survey

Louisville, CO 1:24,000, 1979

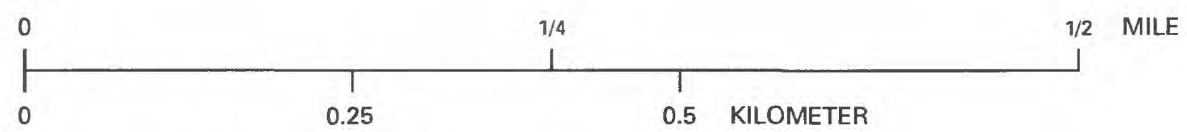

Figure 3. Location of sampling sites in Great Western Reservoir. 


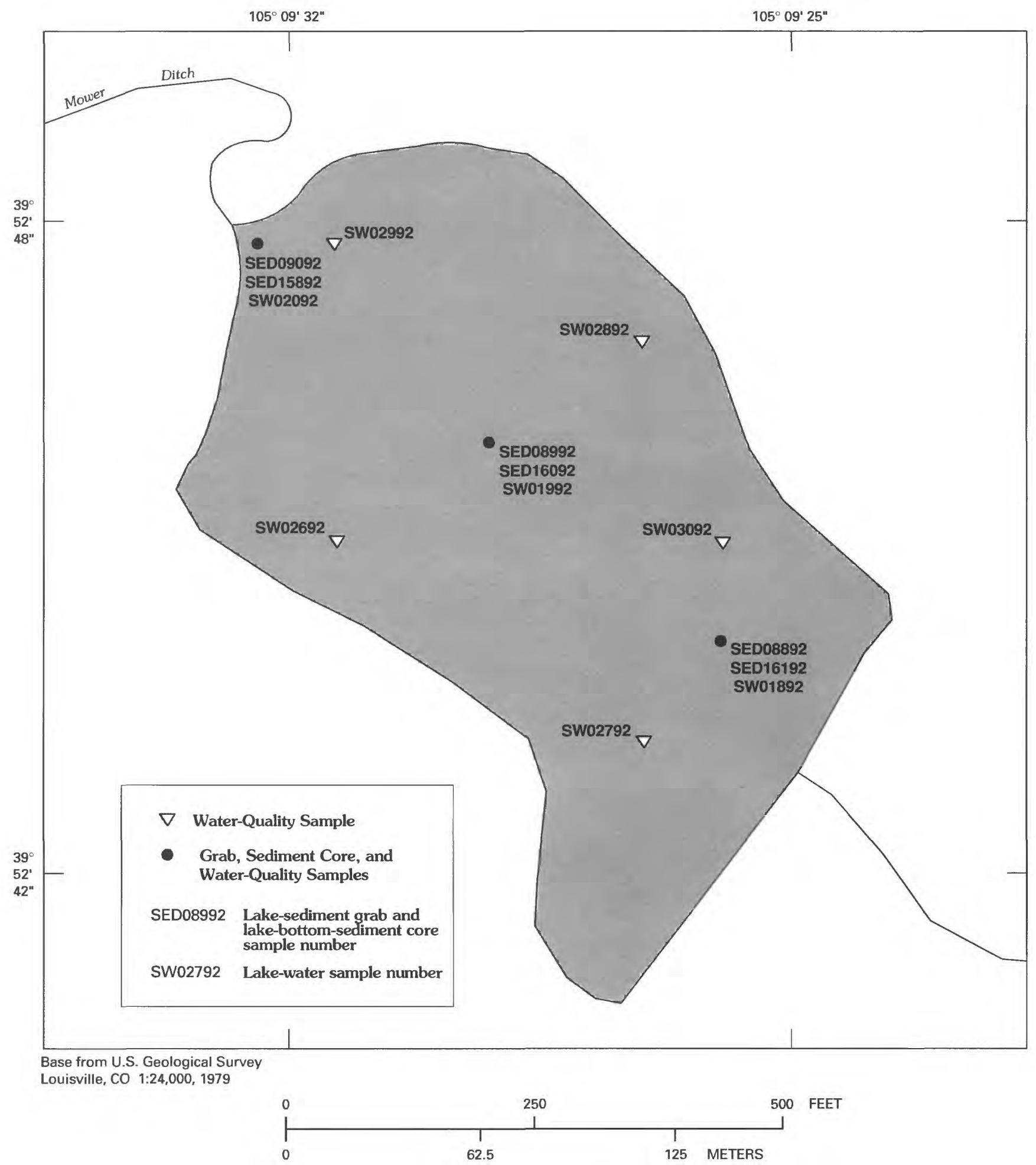

Figure 4. Location of sampling sites in Mower Reservoir. 
was for analysis of trace elements, selected major ions, and cyanide. This procedure was repeated for the entire length of each core.

A physical description of the core material was done on one of the two cores collected from each lakebottom sampling site (table B-1 in Appendix B). The core was extruded horizontally onto a table covered with white paper. The core was split in half longitudinally, using a spatula, to reveal the middle of the core. A yardstick was aligned along the side of the core for measuring purposes. The core material was photographed and qualitatively described in terms of color, texture, and other features. Core color was determined using the Munsell soil color chart standards.

Lake-bottom-sediment cores for chemical analyses were obtained from four sites at Standley Lake (fig. 2) on Sept. 8-9. Core lengths ranged from 8 in. at the Woman Creek bay site (SED08292) to 36 in. at the sampling site (SED08192) near the dam. Lakebottom-sediment core samples were collected from five sites at Great Western Reservoir during 1992 (fig. 3) from Aug. 31-Sept. 2, and Sept. 15. Core lengths ranged from $9 \mathrm{in}$. at the Walnut Creek bay site (SED09292) to $31 \mathrm{in}$. at the site (SED09192) near the dam. Lake-bottom-sediment cores were obtained from three sites at Mower Reservoir (fig. 4) on Sept. 14. The cores ranged in length from 11 in. at the inlet of Mower Ditch site (SED09092) to 22 in. near the damsite (SED08992). The chemical analyses of the lakebottom-sediment cores included radionuclides, selected major ions, trace elements, and cyanide. Attempts were made to obtain single core lengths of as much as $\mathbf{4 5}$ in.; however, some attempts were not successful. The low core recoveries could have been because of the physical characteristics of the sediment and limitations of the coring equipment.

\section{Lake-Water Sampling}

Water samples from the lakes were collected by using a horizontally suspended Van Dorn discrete-zone sampler. The Van Dorn sampler consists of a PVC cylinder with rigid polyurethane end seals, silicone gaskets, and a latex closing tube. The sampler is about $2 \mathrm{ft}$ long and has a capacity of about $4 \mathrm{~L}$. Samples obtained during the lake-bottom coring were collected about 1 to $1-1 / 2 \mathrm{ft}$ from the bottom of the lake. During the Oct. aquatic sampling, water samples were collected at various depths based on the total depth at each sampling point. The water was decanted from the Van Dorn sampler into a clean 20-L carboy.

The water samples were taken to a shore station for preparation, containerizing, and preservation. All aliquots were taken from the $20-\mathrm{L}$ carboy used to composite the samples on the boat. Samples for total concentrations were poured directly from the 20-L carboy, which was gently inverted several times to resuspend particulates, into the sample bottles. Samples for dissolved concentrations were pumped from the 20 - $\mathrm{L}$ carboy through a $0.45-\mu \mathrm{m}$ cellulosemembrane filter. The filter cartridge was flushed with $1 \mathrm{~L}$ of deionized water and about $500 \mathrm{~mL}$ of native water prior to filtration of samples from each site. The samples were relinquished on the chain-of-custody to the DOE subcontractor for handling and shipping to the laboratories. The DOE subcontractor provided the sample bottles, the sample bottle labeling, the $0.45-\mu \mathrm{m}$ filter cartridges, and the chain-of-custody forms.

Water samples were collected in conjunction with the lake-bottom-sediment coring in Aug. and Sept. 1992 done by the USGS, and with the Oct. 1992 aquatic sampling done by the DOE subcontractor. Water samples were collected in July 1992 by the DOE subcontractor.

Field measurements were made at each watersampling site at all three lakes (table $\mathrm{C}-1$ in appendix $\mathrm{C}$ at the back of this report) using a multi-parameter measuring instrument. The parameters measured with the multi-parameter measuring instrument included water temperature, dissolved oxygen (DO), $\mathrm{pH}$, and specific conductance. These field parameters were measured prior to the collection of water samples to develop a lake profile. By observing the water temperature and the $\mathrm{DO}$, a determination of lake stratification could be made. No lake stratification was detected during the Oct. water sampling, so samples were composited from surface, middle, and bottom depths.

Four lake-bottom water samples were collected from Standley Lake during 1992 on Sept. 8 -9 (fig. 2), five were collected from Great Western Reservoir from Aug. 31-Sept. 2 and on Sept. 15 (fig. 3), and three were collected from Mower Reservoir on Sept. 14 (fig. 4). The analyses of these water samples included radionuclides (table C-2 in Appendix C), trace elements, major ions, herbicides, nutrients, cyanide, and sulfide (table C-3 in Appendix C).

Water sampling, coinciding with the aquatic sampling performed by the DOE subcontractor at all three reservoirs, was done in Oct. 1992. Five waterquality samples were collected from Standley Lake on Oct. 13-14 (fig. 2), four were collected at Great Western Reservoir on Oct. 2 (fig. 3), and five were collected from Mower Reservoir on Oct. 8 (fig. 4). The analyses of these water samples included radionuclides (table C2 in Appendix C), trace elements, major ions, nutrients, dissolved and suspended solids, oil and grease, pesticides, and volatile organic compounds (table C-3 in Appendix C). 


\section{Quality-Assurance Procedures and Analytical Methods}

Quality-assurance procedures associated with sampling, sample preparation, and sample shipping were overseen by the DOE subcontractor. The qualityassurance activities were accomplished according to quality requirements (EG\&G Rocky Flats Inc., 1991).

The types of quality-assurance samples collected at the sediment- and water-sampling sites consisted of duplicate samples and equipment rinsates. Duplicate samples were collected to provide an indication of overall sampling precision (U.S. Department of Energy, 1990). These duplicate samples were collected immediately after the regular samples were collected using the same sampling techniques. Equipmentrinsate samples were collected as a check on the potential for sample contamination by the sampling equipment. The equipment-rinsate samples were collected by containerizing deionized water that was used to rinse the various decontaminated sampling equipment. The frequency of the duplicate sample collection was 1 in every 10 regular sediment and water samples collected. Summary statistics for radionuclide concentrations in duplicate samples and differences in measured concentrations are in table 1 . The frequency of the equipment-rinsate sample collection was 1 in every 20 regular sediment and water samples collected, and summary statistics for radionuclide concentrations in equipment rinsates are presented in table 2. Quality assurance for the field measurements consisted of

Table 1. Summary statistics for radionuclide concentrations in duplicate samples

[n, number of samples]

\begin{tabular}{|c|c|c|c|c|c|c|c|}
\hline \multirow{2}{*}{ Grab } & \multicolumn{7}{|c|}{$\begin{array}{l}\text { Total radionuclides } \\
\text { (picocuries per gram) }\end{array}$} \\
\hline & $\begin{array}{c}\text { Americium- } \\
241\end{array}$ & $\begin{array}{l}\text { Gross } \\
\text { alpha }\end{array}$ & $\begin{array}{c}\text { Gross } \\
\text { beta }\end{array}$ & $\begin{array}{c}\text { Plutonium- } \\
239,240\end{array}$ & $\begin{array}{l}\text { Uranium- } \\
233,234\end{array}$ & $\begin{array}{l}\text { Uranium- } \\
235\end{array}$ & $\begin{array}{l}\text { Uranium- } \\
238\end{array}$ \\
\hline Mean difference in concentrations & 0.028 & 2.9 & 2.3 & 0.050 & 0.066 & 0.044 & 0.211 \\
\hline Mean concentration & .049 & 22.5 & 25.6 & .129 & 1.310 & .059 & 1.289 \\
\hline n & 5 & 6 & 6 & 6 & 6 & 6 & 6 \\
\hline
\end{tabular}

\begin{tabular}{|c|c|c|c|c|c|c|}
\hline \multirow{2}{*}{ Core } & \multicolumn{6}{|c|}{$\begin{array}{l}\text { Total radionuclides } \\
\text { (picocuries per gram) }\end{array}$} \\
\hline & $\begin{array}{c}\text { Americium- } \\
241\end{array}$ & $\begin{array}{l}\text { Plutonium- } \\
239,240\end{array}$ & $\begin{array}{l}\text { Polonium - } \\
210\end{array}$ & $\begin{array}{l}\text { Uranium- } \\
233,234\end{array}$ & $\begin{array}{l}\text { Uranium- } \\
235\end{array}$ & $\begin{array}{l}\text { Uranium- } \\
238\end{array}$ \\
\hline Mean difference in concentrations & .014 & .153 & .160 & .166 & .038 & .144 \\
\hline Mean concentration & .117 & .783 & 1.797 & 1.458 & 0.068 & 1.462 \\
\hline $\mathrm{n}$ & 4 & 7 & 6 & 7 & 7 & 7 \\
\hline
\end{tabular}

\begin{tabular}{|c|c|c|c|c|c|c|c|}
\hline \multirow{2}{*}{ Water } & \multicolumn{7}{|c|}{$\begin{array}{l}\text { Dissolved radionuclides } \\
\text { (picocuries per liter) }\end{array}$} \\
\hline & $\begin{array}{l}\text { Americium- } \\
241\end{array}$ & $\begin{array}{l}\text { Gross } \\
\text { alpha }\end{array}$ & $\begin{array}{l}\text { Gross } \\
\text { beta }\end{array}$ & $\begin{array}{l}\text { Plutonium- } \\
239,240\end{array}$ & $\begin{array}{l}\text { Uranium- } \\
233,234\end{array}$ & $\begin{array}{l}\text { Uranium- } \\
235\end{array}$ & $\begin{array}{l}\text { Uranium- } \\
238\end{array}$ \\
\hline Mean difference in concentrations & .002 & .6 & .3 & .001 & .185 & .059 & .129 \\
\hline Mean concentration & .003 & .5 & 1.4 & .001 & .541 & .034 & .334 \\
\hline $\mathbf{n}$ & 3 & 3 & 3 & 3 & 3 & 3 & 3 \\
\hline
\end{tabular}

\begin{tabular}{lcccccccc}
\multicolumn{1}{c}{ Water } & \multicolumn{8}{c}{$\begin{array}{c}\text { Total radionuclides } \\
\text { (picocuries per IIter) }\end{array}$} \\
\cline { 2 - 9 } & $\begin{array}{c}\text { Americium- } \\
\mathbf{2 4 1}\end{array}$ & $\begin{array}{c}\text { Gross } \\
\text { alpha }\end{array}$ & $\begin{array}{c}\text { Gross } \\
\text { beta }\end{array}$ & $\begin{array}{c}\text { Plutonium- } \\
\mathbf{2 3 9 , 2 4 0}\end{array}$ & $\begin{array}{c}\text { Uranium- } \\
\mathbf{2 3 3 , 2 3 4}\end{array}$ & $\begin{array}{c}\text { Uranium- } \\
\mathbf{2 3 5}\end{array}$ & $\begin{array}{c}\text { Uranium- } \\
\mathbf{2 3 8}\end{array}$ \\
\hline Mean difference in concentration & .007 & 1.9 & .9 & .002 & .137 & .042 & .238 \\
Mean concentration & .006 & 1.7 & 2.0 & .003 & .503 & .018 & .457 \\
$\mathrm{n}$ & 5 & 5 & 5 & 5 & 5 & 5 & 4 \\
\hline
\end{tabular}

10 Characterization of Selected Radionuclides in Sediment and Surface Water in Standley Lake, Great Western Reservoir, and Mower Reservoir, Jefferson County, Colorado, 1992 
Table 2. Summary statistics for radionuclide concentrations in equipment rinsates

[n. number of samples]

\begin{tabular}{|c|c|c|c|c|c|c|c|}
\hline \multirow{2}{*}{ Sediment cores } & \multicolumn{7}{|c|}{$\begin{array}{l}\text { Total radionuclides } \\
\text { (picocuries per gram) }\end{array}$} \\
\hline & $\begin{array}{l}\text { Americium- } \\
241\end{array}$ & $\begin{array}{l}\text { Gross } \\
\text { alpha }\end{array}$ & $\begin{array}{c}\text { Gross } \\
\text { beta }\end{array}$ & $\begin{array}{l}\text { Plutonium- } \\
239,240\end{array}$ & $\begin{array}{l}\text { Uranium- } \\
233,234\end{array}$ & $\begin{array}{l}\text { Uranium- } \\
235\end{array}$ & $\begin{array}{l}\text { Uranium } \\
238\end{array}$ \\
\hline Mean & 0.001 & -0.167 & 0.185 & 0.001 & 0.060 & -0.003 & 0.065 \\
\hline Standard deviation & .001 & .384 & .654 & .002 & .075 & .014 & .088 \\
\hline $\mathbf{n}$ & 8 & 7 & 7 & 8 & 8 & 8 & 8 \\
\hline
\end{tabular}

\begin{tabular}{lccccccc} 
& \multicolumn{9}{c}{$\begin{array}{c}\text { Dissolved radionuclides } \\
\text { (picocuries per liter) }\end{array}$} \\
\cline { 2 - 9 } & $\begin{array}{c}\text { Americium- } \\
\text { Water }\end{array}$ & $\begin{array}{c}\text { Gross } \\
\text { alpha }\end{array}$ & Gross beta & $\begin{array}{c}\text { Plutonium- } \\
\mathbf{2 3 9 , 2 4 0}\end{array}$ & $\begin{array}{c}\text { Uranium- } \\
\mathbf{2 3 3 , 2 3 4}\end{array}$ & $\begin{array}{c}\text { Uranium- } \\
\mathbf{2 3 5}\end{array}$ & $\begin{array}{c}\text { Uranium- } \\
\mathbf{2 3 8}\end{array}$ \\
\hline Mean & .005 & .305 & -.440 & .002 & .196 & .003 & .200 \\
Standard deviation & .005 & .204 & .629 & .002 & .181 & .018 & .172 \\
$\mathrm{n}$ & 4 & 4 & 4 & 4 & 4 & 4 & 4 \\
\hline \hline
\end{tabular}

\begin{tabular}{|c|c|c|c|c|c|c|c|}
\hline \multirow{2}{*}{ Water } & \multicolumn{7}{|c|}{$\begin{array}{l}\text { Total radionuclides } \\
\text { (picocuries per liter) }\end{array}$} \\
\hline & $\begin{array}{c}\text { Americium- } \\
241\end{array}$ & $\begin{array}{l}\text { Gross } \\
\text { alpha }\end{array}$ & Gross beta & $\begin{array}{l}\text { Plutonium- } \\
239,240\end{array}$ & $\begin{array}{l}\text { Uranium- } \\
233,234\end{array}$ & $\begin{array}{l}\text { Uranium- } \\
\quad 235\end{array}$ & $\begin{array}{l}\text { Uranium- } \\
\quad 238\end{array}$ \\
\hline Mean & .671 & .877 & .447 & .668 & .814 & .669 & .832 \\
\hline Standard deviation & 1.631 & 1.531 & 1.804 & 1.632 & 1.562 & 1.632 & 1.554 \\
\hline $\mathrm{n}$ & 6 & 6 & 6 & 6 & 6 & 6 & 6 \\
\hline
\end{tabular}

equipment inspection and calibration for each fieldparameter measurement according to requirements (EG\&G Rocky Flats, Inc., 1991).

Analytical methods for sediment and waterquality tests were provided by the U.S. Department of Energy (1990). Quality-assurance procedures for sample analyses and analytical data validation are outlined by the U.S. Department of Energy (1994). All analyses in this report met data-validation criteria.

\section{Statistical Data-Analysis Techniques}

To test for differences in analyte levels between the lakes, samples from each lake were grouped, and a Kruskal-Wallis test was applied to determine whether sample distributions were the same, or in some cases, whether medians of sample groups were the same. This test was used to identify differences in lakesediment grab data and lake-water-quality results between lakes based on the 1992 data.

In the comparison of results for ${ }^{239,240} \mathrm{Pu}$ in lakesediment grab samples and lake-bottom-sediment core samples collected in 1983-84 and in 1992, grab samples and core samples were evaluated independently. Results where concentrations were less than the reported detection limit were included in all statistical tests, and all data included in this report are uncensored. Uncensored data were used because removal or substitution of data below the detection limit can introduce bias into statistical analyses (Gilliom and others, 1984; Porter and others, 1988). Nonparametric statistical techniques were used because most data sets were not distributed normally.

Matched pairs of data were identified as samples that were collected in the same location in the 1983-84 and 1992 studies. Results for groups of matched pairs were compared using either a sign test or a Wilcoxon signed-rank test, depending on whether the differences between the data sets were symmetrically distributed. Although the signed-rank test provides more power when differences are symmetrical, the test is inappropriate where differences are asymmetric (Helsel and Hirsh, 1992; Ott, 1993). For matched pairs, the sign test determines whether $\mathrm{x}$ is generally larger or smaller than $y$, whereas the signed-rank test determines whether the median difference between paired observations is equal to zero (Helsel and Hirsh, 1992). 
STATISTICAL ANALYSES OF RADIONUCLIDE CONCENTRATIONS

\section{Lake-Sediment Grab Samples}

\section{Data}

Maximum concentrations of ${ }^{239,240} \mathrm{Pu}$ and ${ }^{241} \mathrm{Am}$ in sediment grab samples from all three study lakes were greater than the range of background concentrations, roughly $\leq 0.1 \mathrm{pCi} / \mathrm{g}$, expected from natural processes and fallout (U.S. Environmental Protection Agency, 1973, 1975). The concentration of ${ }^{239.240} \mathrm{Pu}$ in lake-sediment grab samples for the three study lakes is shown in figure 5. Concentrations of ${ }^{239,240} \mathrm{Pu}$ were highest in Mower Reservoir sediment and lowest in sediment in Standley Lake. Boxplots of ${ }^{239,240} \mathrm{Pu}$ concentration are shown in figure 6. Summary statistics for radionuclide concentrations in all lake-sediment grab samples and groups of grab samples separated according to lake are listed in table 3. Median 239,240 Pu concentrations in Standley Lake, Great Western Reservoir, and Mower Reservoir were 0.037 , 0.105 , and $0.351 \mathrm{pCi} / \mathrm{g}$, respectively, and the differences between the reservoirs were statistically significant at $\mathrm{p}<0.05$.

The ${ }^{239,240} \mathrm{Pu}$ concentrations in Mower Reservoir were considerably higher than background levels measured in lake sediment in the Front Range of Colorado. For comparison, in a previous study (Cohen and others, 1990), mean ${ }^{239,240} \mathrm{Pu}$ concentrations in the top 4 in. of sediment from two unaffected Front Range lakes, Wellington Lake and Halligan Reservoir, were 0.094 and $0.027 \mathrm{pCi} / \mathrm{g}$. Trends among the lakes used in this study were in agreement with the patterns of 239,240 Pu concentration reported for soil surrounding Rocky Flats (Hardy and others, 1980) and indicated that sediment in Mower Reservoir has the highest concentrations of ${ }^{239,240} \mathrm{Pu}$ of the three study lakes. These findings are consistent with the fact that Mower Reservoir is closest to the drum storage site at Rocky Flats.

The mean concentration of ${ }^{241} \mathrm{Am}$ in lakesediment grab samples was highest in Great Western Reservoir and lowest in Standley Lake (fig. 7, table 3). However, ${ }^{241}$ Am concentrations in sediment from Great Western Reservoir varied considerably and were substantially skewed; the median value was higher in Mower Reservoir than in Great Western Reservoir and Standley Lake (fig. 8, table 3). The difference in the median values of samples from Mower Reservoir and Standley Lake was significant at $p<0.05$.

\section{Comparison Between 1983-84 and 1992 Data}

When all lake-sediment grab sample data collected in 1983-84 were considered as one group, and all analogous data from 1992 were considered as another group, there was no statistically significant difference in the distributions of the data sets $(p>0.05)$. However, when lake-sediment grab data from Standley Lake and Great Western Reservoir were considered separately, there was a statistically significant differ * ence at Great Western Reservoir $(p<0.05)$ and not at Standley Lake (no samples were taken from Mower Reservoir in 1983-84). Boxplots showing means, medians, and quartiles for the 1983-84 and 1992 data, as well as differences between the two data sets for colocated samples, are shown in figure 9. At Standley Lake, there seemed to be no consistent difference between the 1983-84 and the 1992 data (fig. 9a), but at Great Western Reservoir, the 1983-84 data had more spread than the 1992 data, and ${ }^{239,240}$ Pu concentrations tended to be higher in 1983-84 (fig. 9b). The median difference between data sets at Great Western Reservoir was $0.040 \mathrm{pCi} / \mathrm{g}$, and the mean difference was $0.140 \mathrm{pCi} / \mathrm{g}$. The mean difference was substantially greater than the median difference because the distribution of differences was skewed; differences were greater at high concentration than at low concentration. Scatterplots of the matched pairs of ${ }^{239,240} \mathrm{Pu}$ concentration data for Standley Lake and Great Western Reservoir are shown in figures 10 and 11. A 1:1 line also is shown to indicate where samples would tend to plot if concentrations in co-located samples were the same in 1983-84 and 1992. Sites where samples had ${ }^{239,240} \mathrm{Pu}$ concentrations below $0.2 \mathrm{pCi} / \mathrm{g}$ in $1983-84$ tended to have similar concentrations in 1992. However, sites where samples had ${ }^{239,240} \mathrm{Pu}$ concentrations above $0.2 \mathrm{pCi} / \mathrm{g}$ in 1983-84 tended to have much lower concentrations in 1992 . The lower ${ }^{239,240} \mathrm{Pu}$ concentrations in 1992 compared to $1983-84$ could be explained by recent deposition of sediments with relatively low ${ }^{239,240} \mathrm{Pu}$ concentrations; the new sediments may have buried the older sediments having somewhat higher concentrations of ${ }^{239,240} \mathrm{Pu}$. It is likely that the sediments with ${ }^{239,240} \mathrm{Pu}$ concentrations between 0.2 and $1.0 \mathrm{pCi} / \mathrm{g}$ still exist but were not sampled because the grab-sampling technique collects only the uppermost 2 to 4 in. of sediment. 

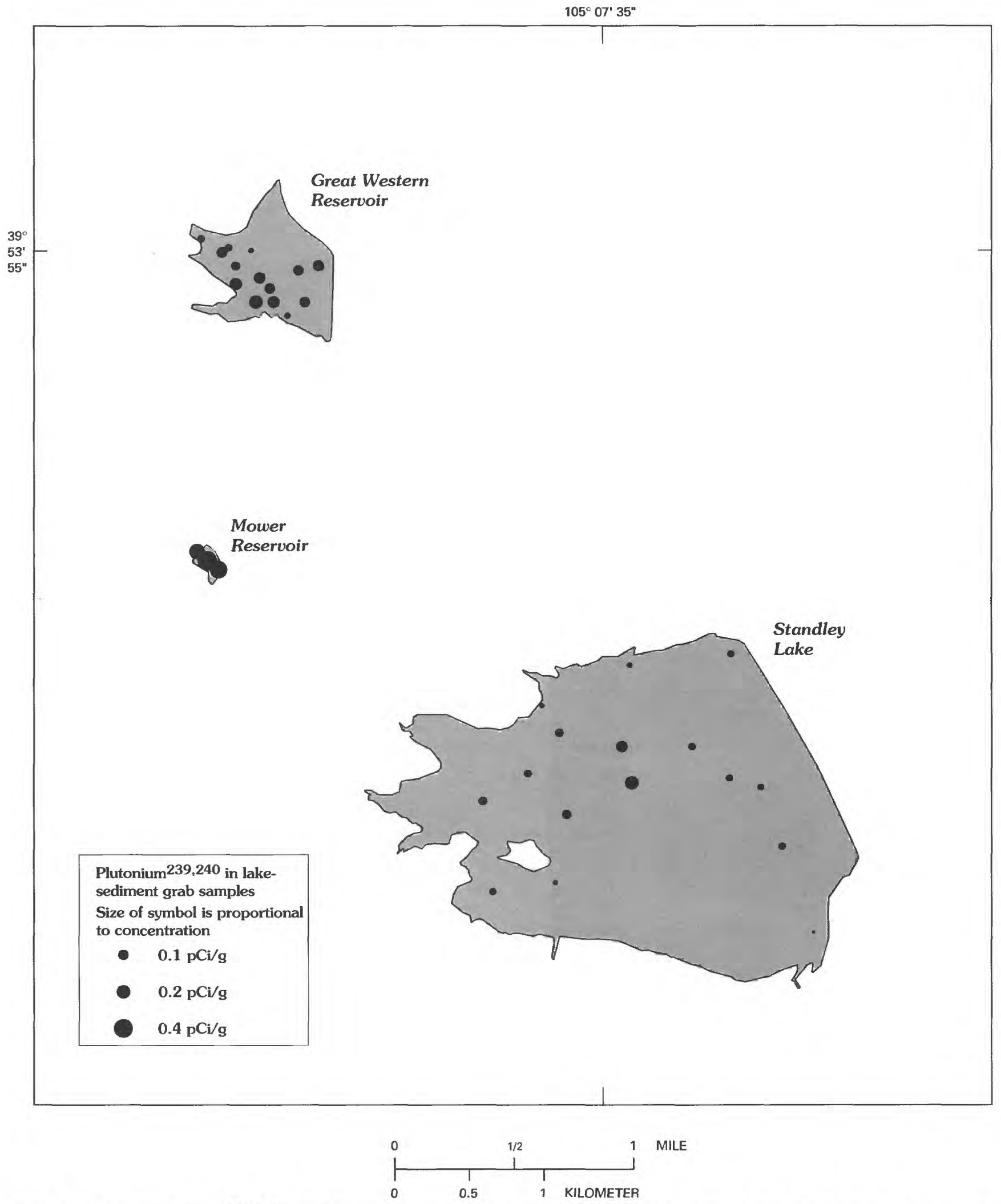

Figure 5. Concentrations of ${ }^{239,240} \mathrm{Pu}$ in lake-sediment grab samples collected from Standley Lake, Great Western Reservoir, and Mower Reservoir. 


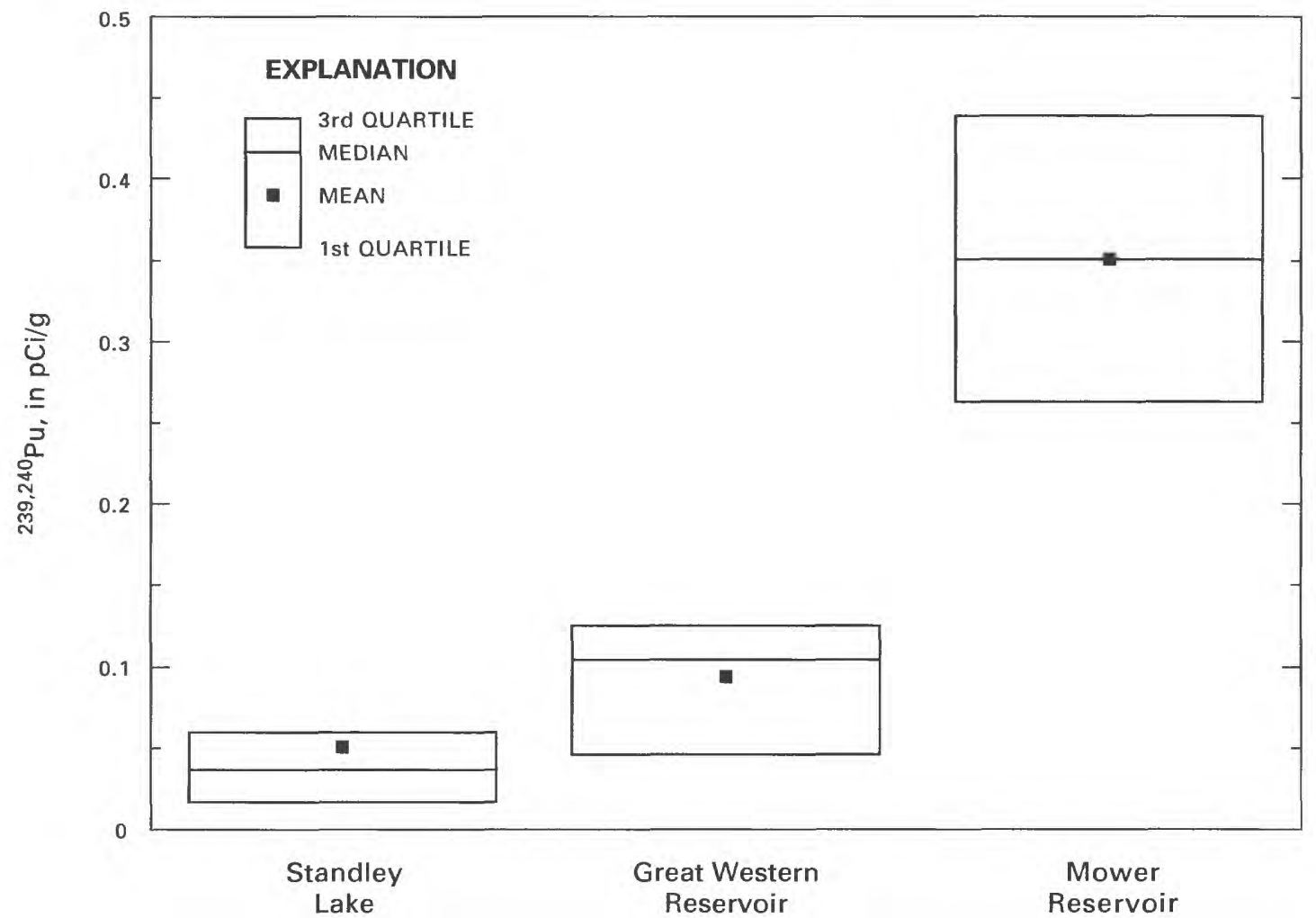

Figure 6. Distribution of ${ }^{239,240} \mathrm{Pu}$ concentrations in lake-sediment grab samples collected from Standley Lake, Great Western Reservoir, and Mower Reservoir.

Table 3. Summary statistics for radionuclide concentrations in lake-sediment grab samples

[Measurements in picocuries per gram; $n$, number of samples; --, not analyzed]

\begin{tabular}{|c|c|c|c|c|c|c|c|c|c|}
\hline \multirow{2}{*}{ Grab sample } & \multirow{2}{*}{ Statistic } & \multirow{2}{*}{$\begin{array}{c}\text { Americium- } \\
241\end{array}$} & \multirow{2}{*}{$\begin{array}{l}\text { Gross } \\
\text { alpha }\end{array}$} & \multirow{2}{*}{ Gross beta } & \multirow{2}{*}{$\begin{array}{c}\text { Plutonium- } \\
239,240\end{array}$} & \multirow{2}{*}{ Tritium } & \multicolumn{3}{|c|}{ Uranium } \\
\hline & & & & & & & 233,234 & 235 & 238 \\
\hline \multirow[t]{4}{*}{ All samples } & Mean & 0.049 & 21.84 & 26.80 & 0.097 & 131.2 & 1.495 & 0.055 & 1.471 \\
\hline & 1st quartile & .013 & 18.43 & 24.11 & .033 & 116.3 & 1.081 & .026 & 1.110 \\
\hline & Median & .033 & 21.46 & 26.82 & .060 & 157.2 & 1.497 & .056 & 1.390 \\
\hline & 3rd quartile & .050 & 24.15 & 29.10 & .125 & 159.1 & 1.895 & .088 & 1.940 \\
\hline \multirow[t]{6}{*}{ Standley Lake } & Mean & .023 & 20.66 & 27.69 & .051 & -- & 1.623 & .050 & 1.567 \\
\hline & Standard deviation & .026 & 4.57 & 4.12 & .050 & - & .685 & .040 & .627 \\
\hline & Ist quartile & .009 & 18.18 & 26.10 & .024 & - & 1.127 & .009 & .880 \\
\hline & Median & .013 & 21.61 & 27.81 & .037 & -- & 1.709 & .053 & 1.862 \\
\hline & 3rd quartile & .029 & 23.96 & 29.58 & .060 & -- & 2.161 & .089 & 2.037 \\
\hline & n & 15 & 16 & 16 & 16 & 0 & 16 & 16 & 16 \\
\hline \multirow{3}{*}{ Great Western Reservoir } & Median & .039 & 21.40 & 25.10 & .105 & 157.2 & 1.391 & .056 & 1.381 \\
\hline & 3rd quartile & .093 & 27.55 & 26.33 & .124 & 159.1 & 1.568 & .084 & 1.558 \\
\hline & n & 15 & 15 & 15 & 14 & 3 & 14 & 14 & 14 \\
\hline \multirow[t]{6}{*}{ Mower Reservoir } & Mean & .062 & 21.31 & 29.81 & .351 & -. & 1.322 & .065 & 1.272 \\
\hline & Standard deviation & .013 & 1.01 & 1.37 & .088 & - & .302 & .040 & .029 \\
\hline & Ist quartile & .055 & 20.86 & 29.03 & .307 & -- & 1.197 & .047 & 1.260 \\
\hline & Median & .060 & 21.50 & 29.17 & .351 & - & 1.406 & .071 & 1.279 \\
\hline & 3rd quartile & .068 & 21.86 & 30.28 & .395 & -. & 1.490 & .086 & 1.288 \\
\hline & n & 3 & 3 & 3 & 3 & 0 & 3 & 3 & 3 \\
\hline
\end{tabular}

14 Characterization of Selected Radionuclides in Sediment and Surface Water in Standley Lake, Great Western Reservoir, and Mower Reservoir, Jefferson County, Colorado, 1992 


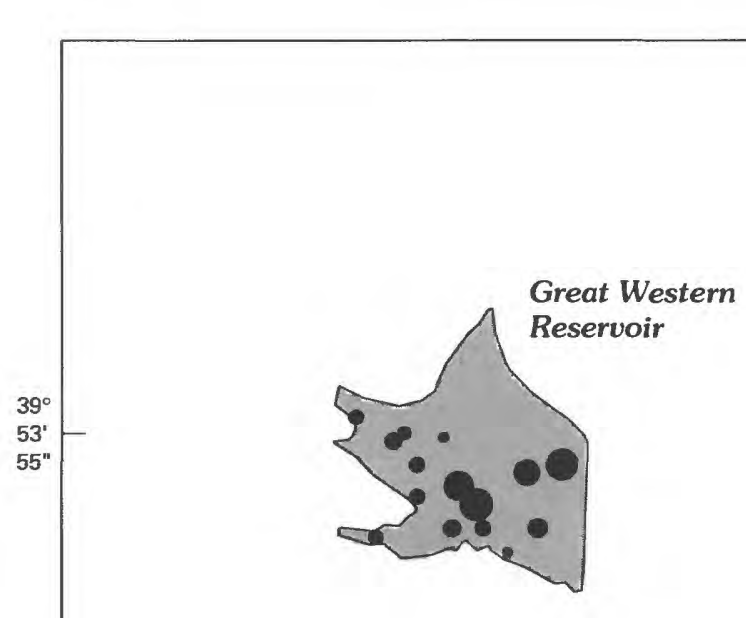

Americium ${ }^{241}$ in lake-sediment grab samples

Size of symbol is proportional to concentration

- $\quad 0.05 \mathrm{pCi} / \mathrm{g}$

- $0.1 \mathrm{pCi} / \mathrm{g}$

Mower

Reservoir

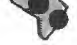

Great Western

Reservoir

$0.2 \mathrm{pCi} / \mathrm{g}$

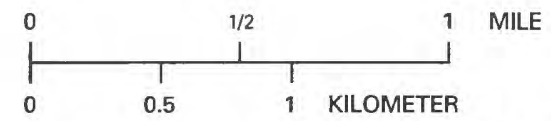

Figure 7. Concentrations of ${ }^{241} \mathrm{Am}$ in lake-sediment grab samples collected from Standley Lake, Great Western Reservoir, and Mower Reservoir. 


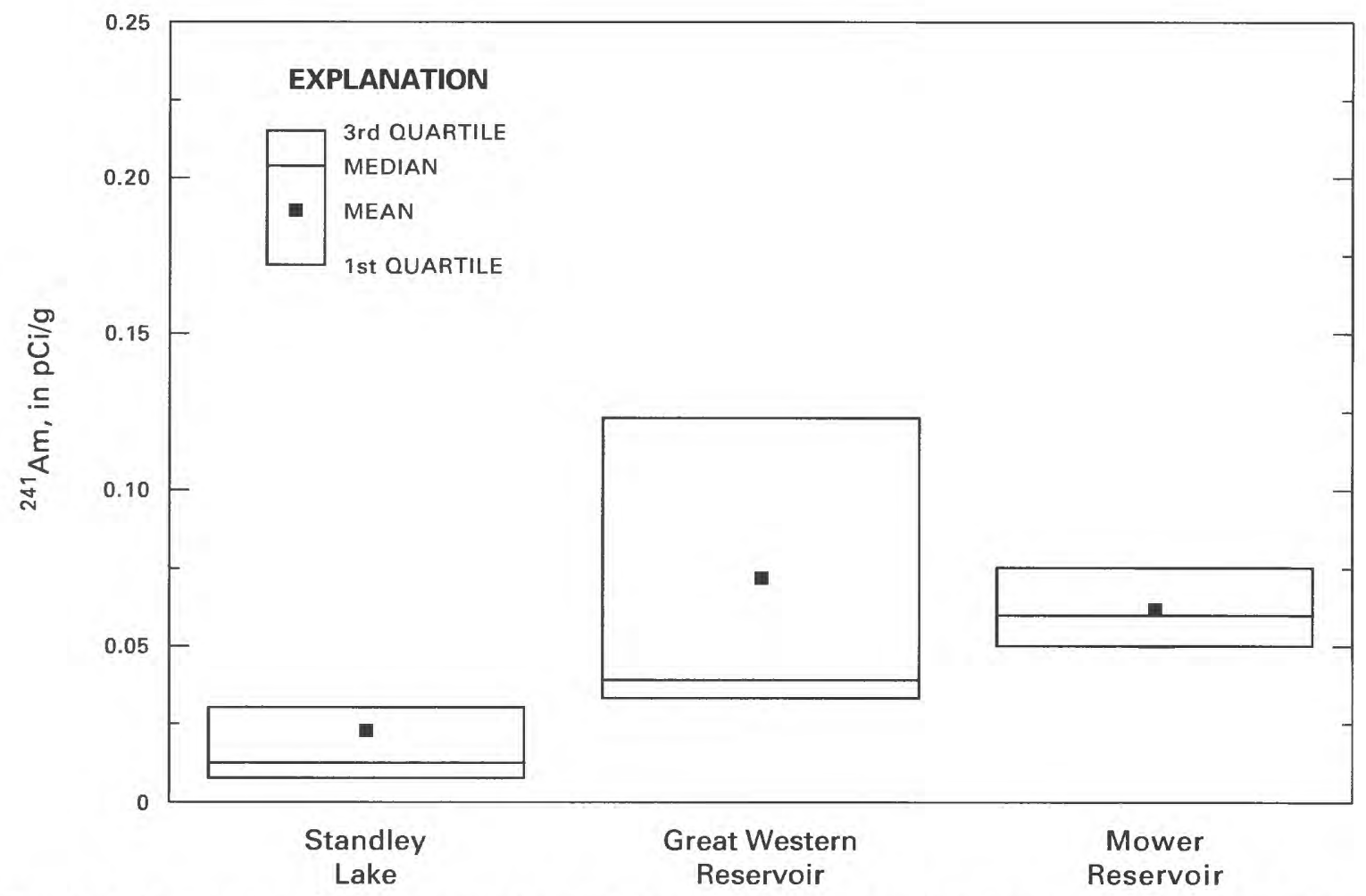

Figure 8. Distribution of ${ }^{241}$ Am concentrations in lake-sediment grab samples collected from Standley Lake, Great Western Reservoir, and Mower Reservoir.

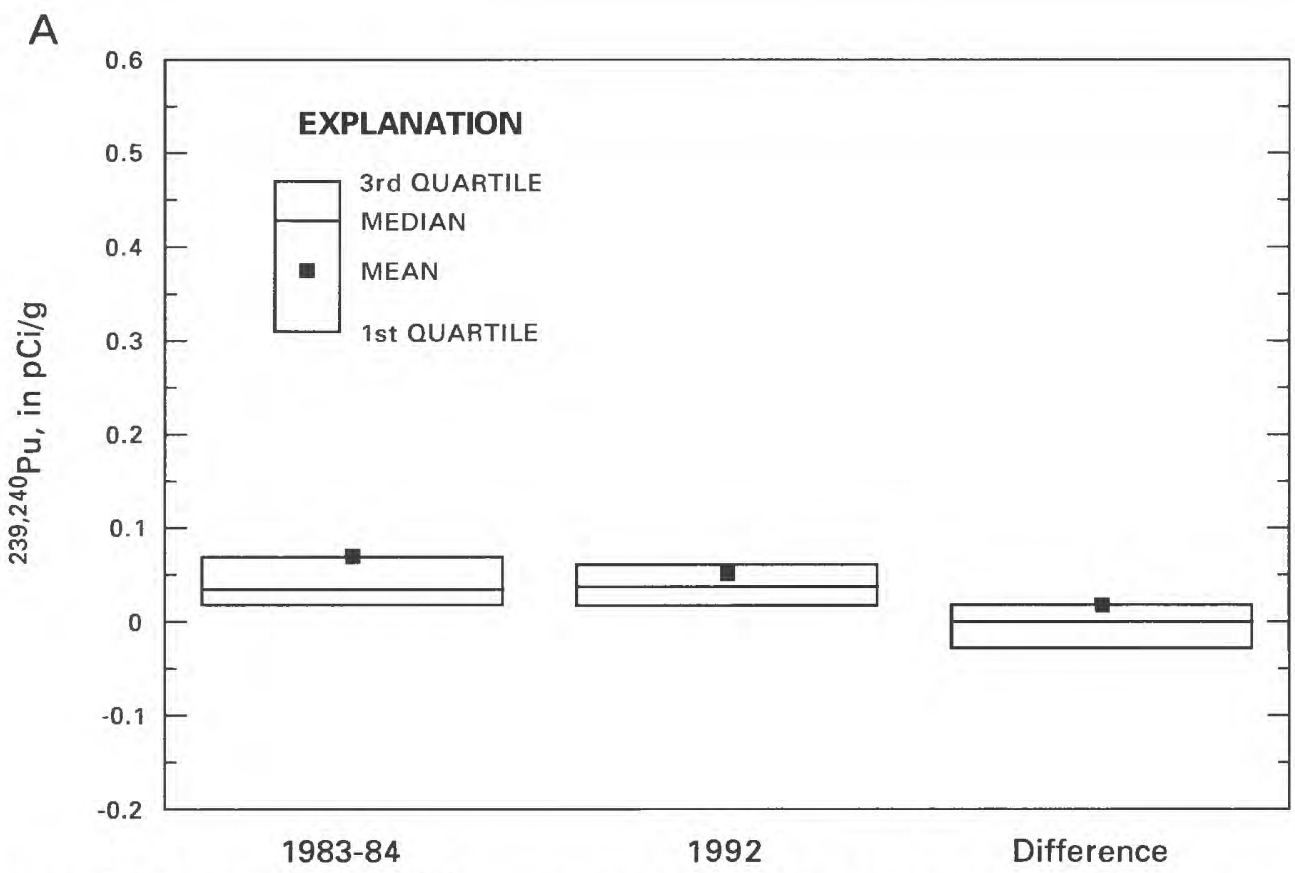

Figure 9A. Distribution of ${ }^{239,240} \mathrm{Pu}$ concentrations in $1983-84$ and 1992 and differences between matched pairs of lake-sediment grab samples at Standley Lake. 


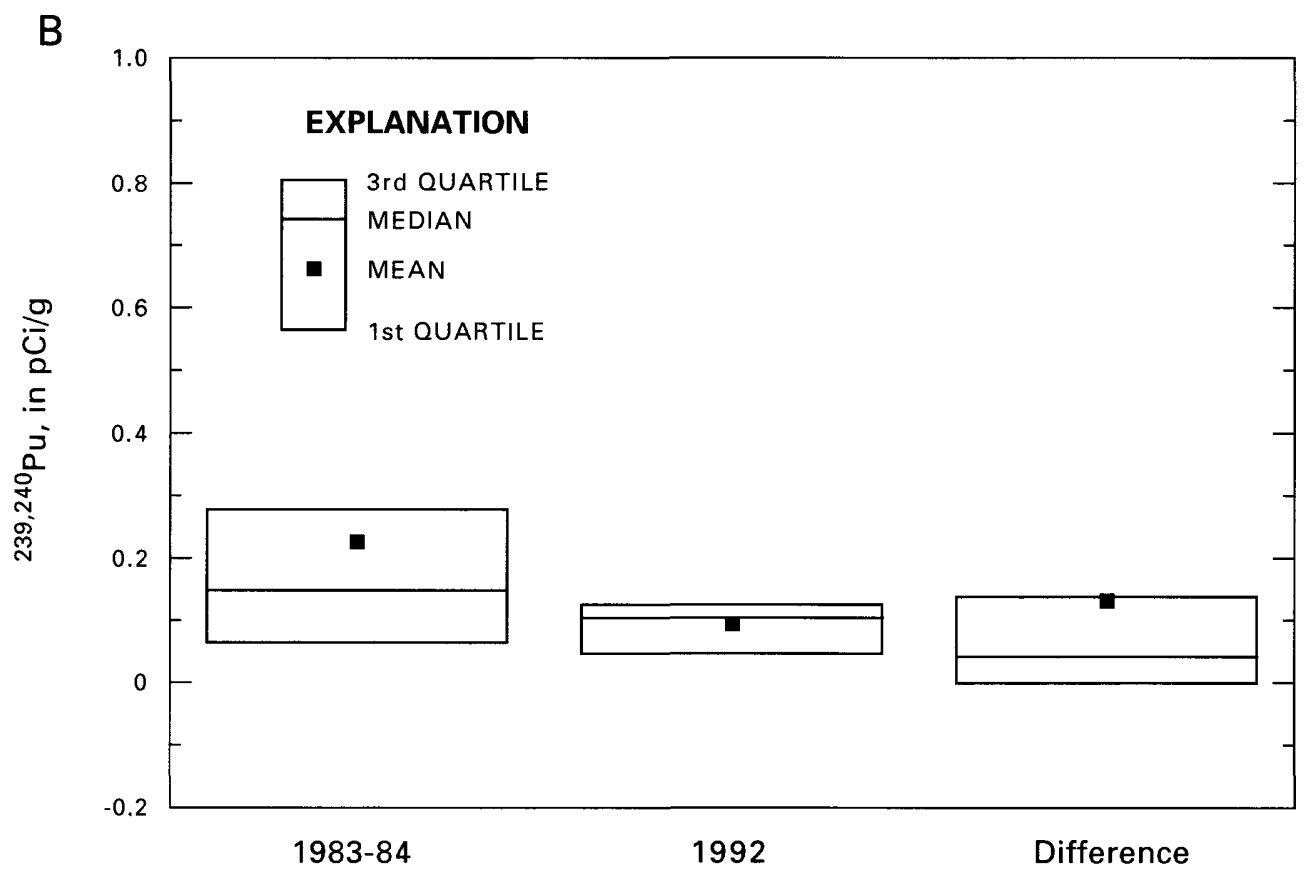

Figure 9B. Distribution of $239,240 \mathrm{Pu}$ concentrations in $1983-84$ and 1992 and differences between matched pairs of lake-sediment grab samples at Great Western Reservoir.

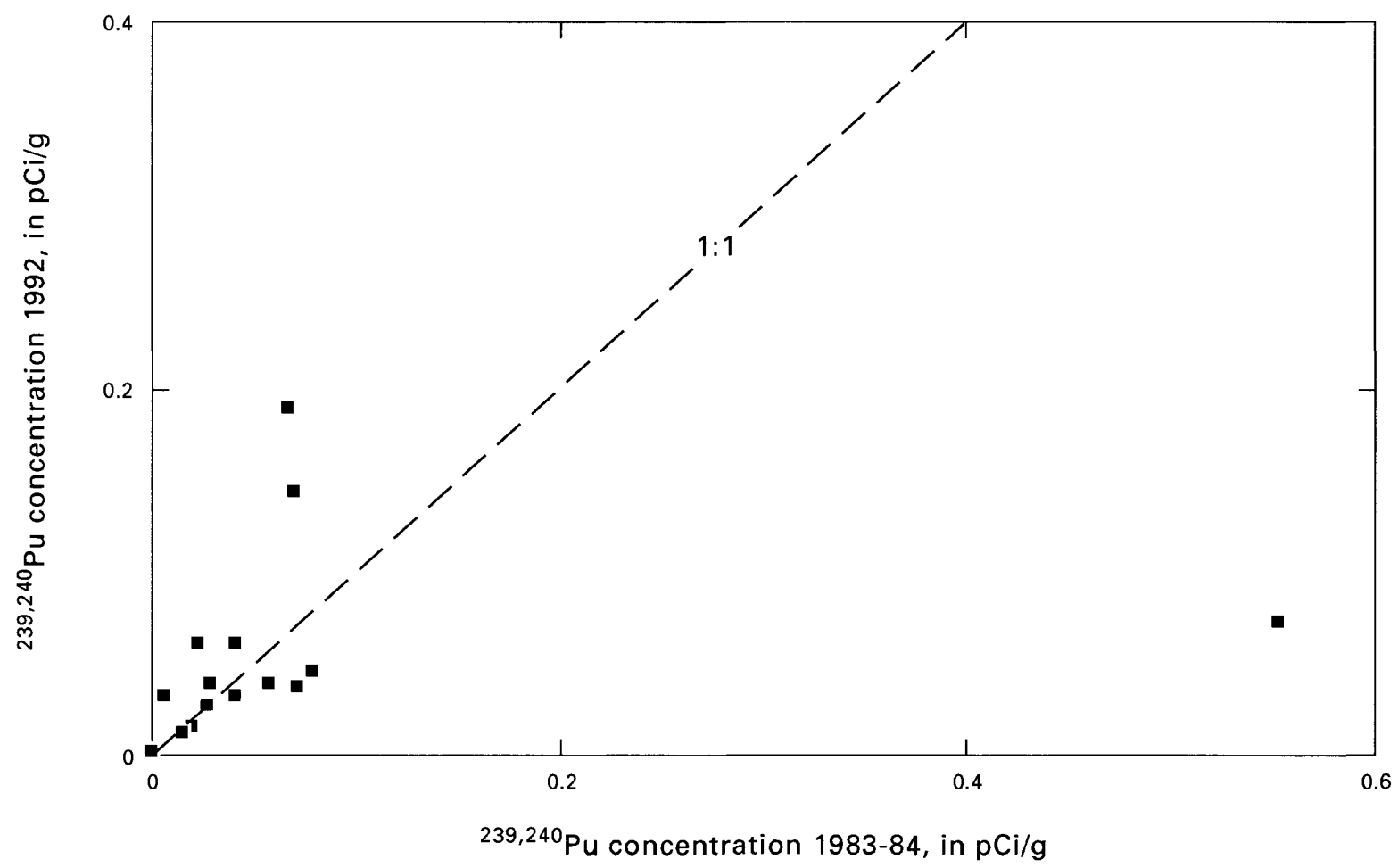

Figure 10. Relation between ${ }^{239,240} \mathrm{Pu}$ concentrations in lake-sediment grab samples collected at co-located sites in 1983-84 and in 1992 at Standley Lake. 


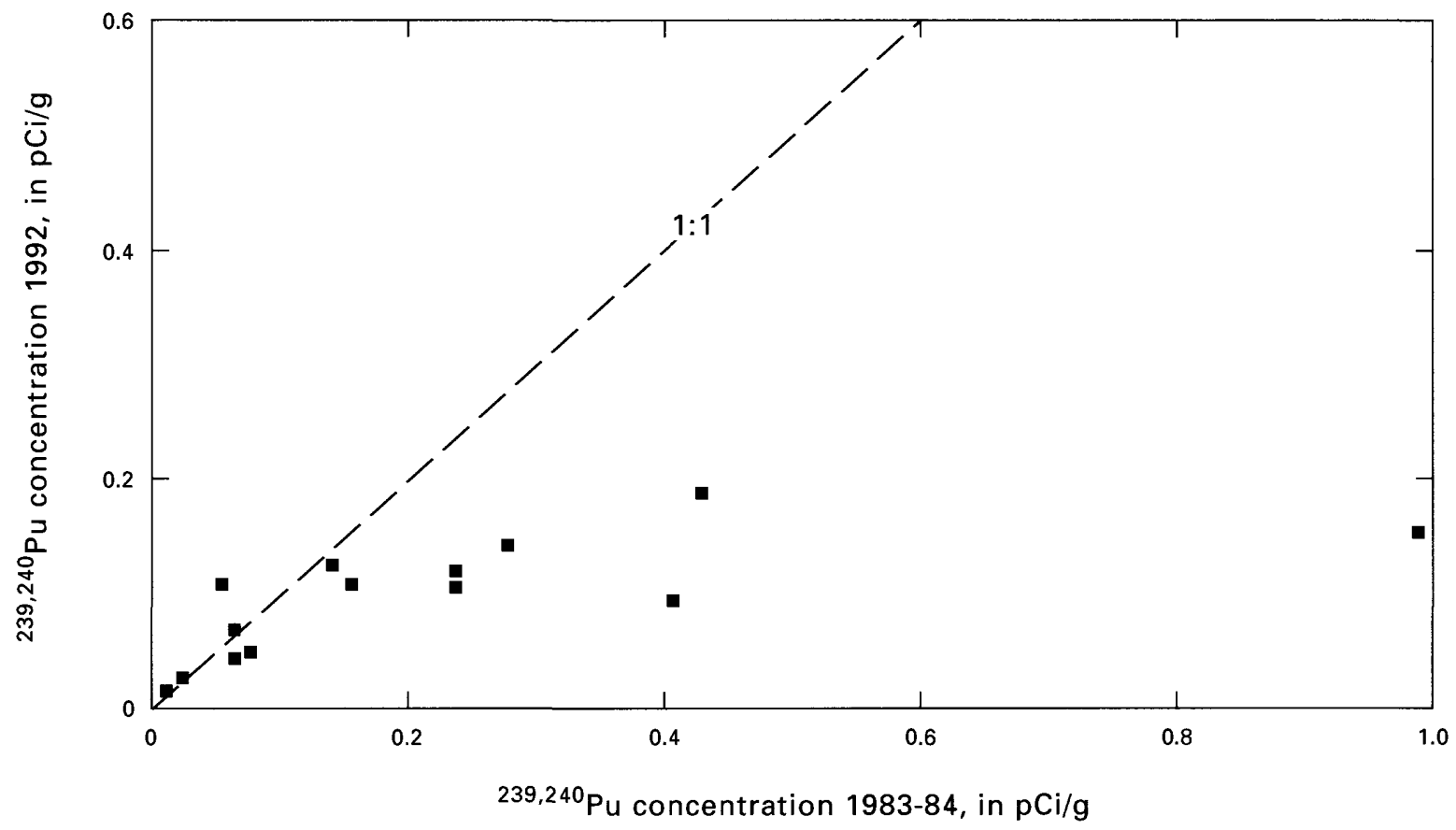

Figure 11. Relation between ${ }^{239,240} \mathrm{Pu}$ concentrations in lake-sediment grab samples collected at co-located sites in 1983-84 and in 1992 at Great Western Reservoir.

\section{Lake-Bottom-Sediment Core Samples}

\section{Data}

As with the lake-sediment grab samples, concentrations of ${ }^{239,240} \mathrm{Pu}$ and ${ }^{241} \mathrm{Am}$ in many of the lake-bottom-sediment core samples were greater than the range of background concentrations expected from natural processes and fallout (U.S. Environmental Protection Agency, 1973, 1975). Concentrations of $239,240 \mathrm{Pu}$ in lake-bottom-sediment cores ranged from about $0 \mathrm{pCi} / \mathrm{g}$ in Standley Lake and Mower Reservoir to $4.030 \mathrm{pCi} / \mathrm{g}$ in Great Western Reservoir (table 4) and had a median of $0.101 \mathrm{pCi} / \mathrm{g}$. Concentrations of ${ }^{241} \mathrm{Am}$ ranged from $0 \mathrm{pCi} / \mathrm{g}$ in Standley Lake and Great Western Reservoir to $1.016 \mathrm{pCi} / \mathrm{g}$ in Great Western Reservoir (table 4) and had a median of $0.021 \mathrm{pCi} / \mathrm{g}$. In most cores, ${ }^{239,240} \mathrm{Pu}$ and ${ }^{241} \mathrm{Am}$ concentrations exhibited a prominent peak at about the same depth, which occurred at depths ranging from 13 to 31 in. An example is shown in figure $12 ;{ }^{239.240} \mathrm{Pu}$ and ${ }^{241} \mathrm{Am}$ concentrations both peak at a depth of 18 in. in core SED08392. Previous investigators have reported a prominent peak in the concentrations of these radionuclides at similar depths (Hardy and others, 1980;

Setlock, 1983; Sackschewsky, 1985; Cohen and others, 1990).

Hardy and others (1980) used the ratio of ${ }^{241} \mathrm{Am}$ to ${ }^{239,240} \mathrm{Pu}$ to identify the predominant sources of
${ }^{239,240} \mathrm{Pu}$ in lake sediment. Krey and others (1976) reported that the ratio of ${ }^{241} \mathrm{Am}$ to ${ }^{239,240} \mathrm{Pu}$ in soil contaminated with Rocky Flats debris was 0.15 .

Livingston and Bowen (1976) noted that global fallout from 1961-62 nuclear testing averaged about 0.24 . Hardy and others (1980) stated that the mean ratio of ${ }^{241} \mathrm{Am}$ to ${ }^{239,240} \mathrm{Pu}$ in lake sediment below the $239,240 \mathrm{Pu}$ concentration peak matched that of fallout. The ${ }^{241} \mathrm{Am}$ to ${ }^{239,240} \mathrm{Pu}$ ratio above the ${ }^{239.240} \mathrm{Pu}$ concentration peak was equal to the ratios typical of contaminated Rocky Flats debris (Hardy and others, 1980). Hardy and others (1980) estimated that 74 to 90 percent of ${ }^{239.240} \mathrm{Pu}$ in sediment above the ${ }^{239,240} \mathrm{Pu}$ concentration peak was derived from Rocky Flats.

By following the method described in Hardy and others (1980), an attempt was made to identify the predominant sources of ${ }^{239,240} \mathrm{Pu}$ in lake-bottom-sediment cores collected in this study. It should be noted that the ratio of ${ }^{241} \mathrm{Am}$ to ${ }^{239,240} \mathrm{Pu}$ increases with time due to decay of ${ }^{241} \mathrm{Pu}$ (half-life $=14.4 \mathrm{yr}$ ) to ${ }^{241} \mathrm{Am}$ after deposition. The ratio of ${ }^{241} \mathrm{Am}$ to ${ }^{239,240} \mathrm{Pu}$ in the core from the middle of Standley Lake is plotted with depth in figure 13. In general, the lowest ratios (fig. 13) occurred near the same depth as the highest concentrations of ${ }^{239,240} \mathrm{Pu}$ and ${ }^{241} \mathrm{Am}$ (fig. 12) in this core, but the ratio had considerable scatter, and the data were inconclusive. Assignment of sources based on these results is not warranted. Furthermore, a plot of 


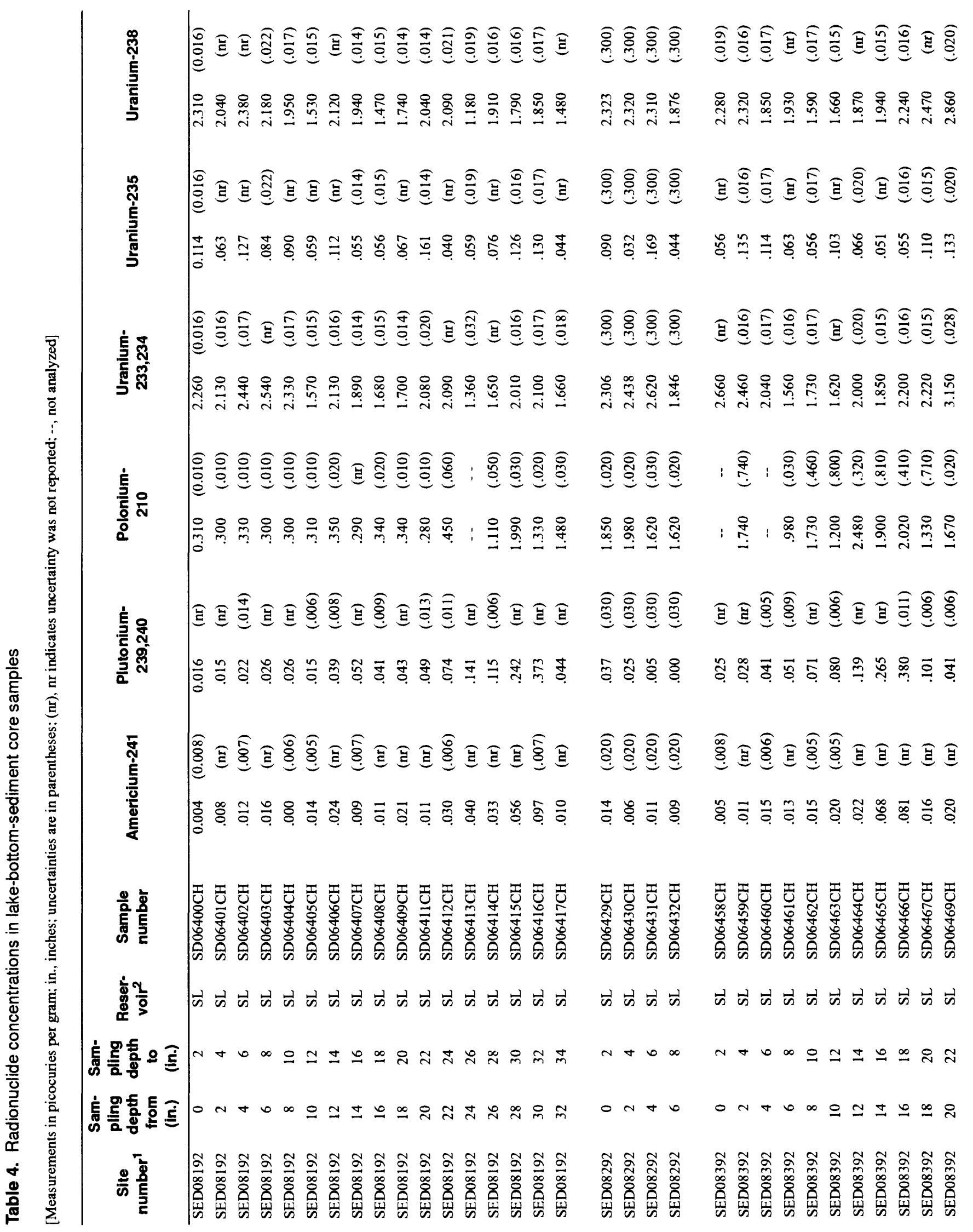




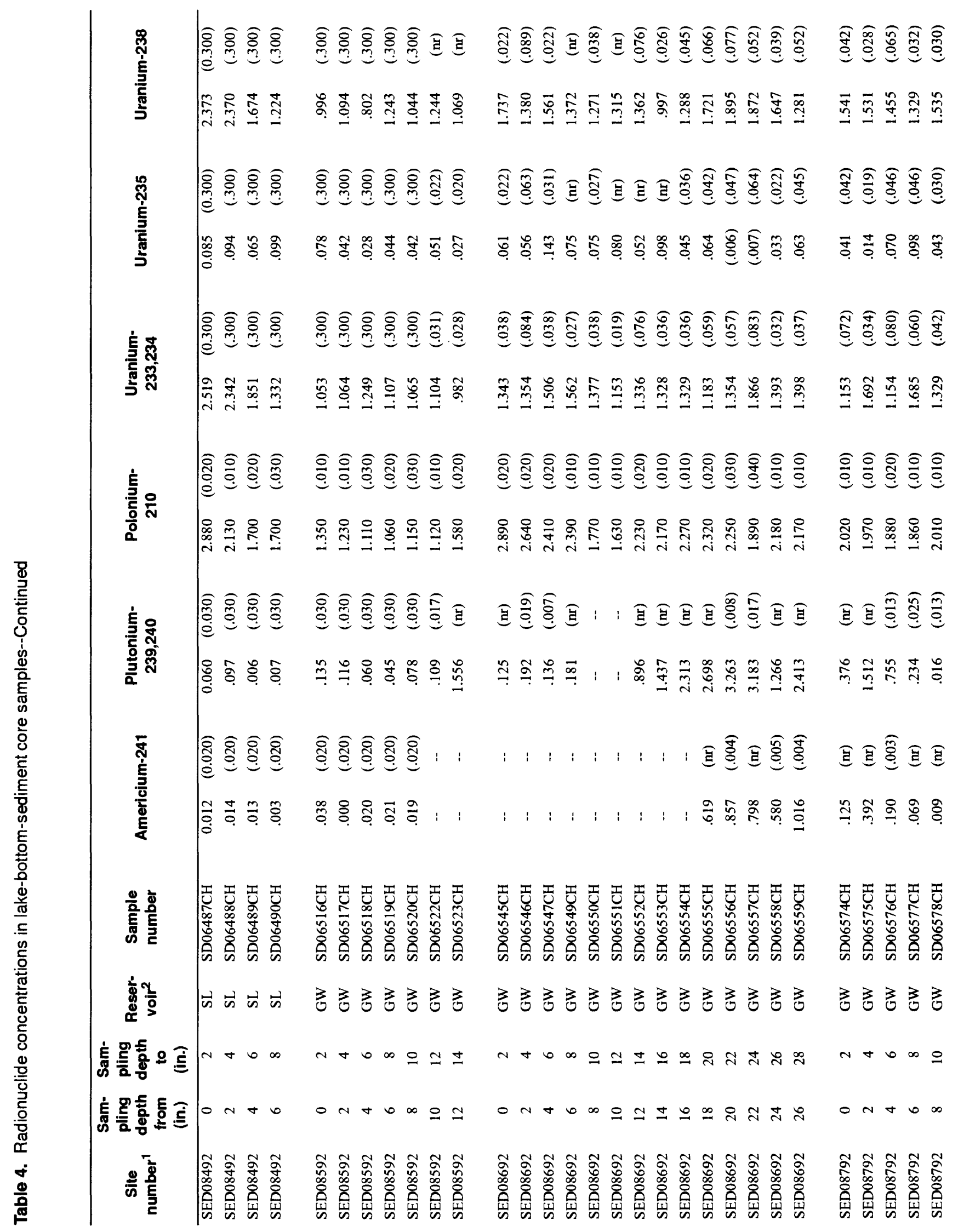




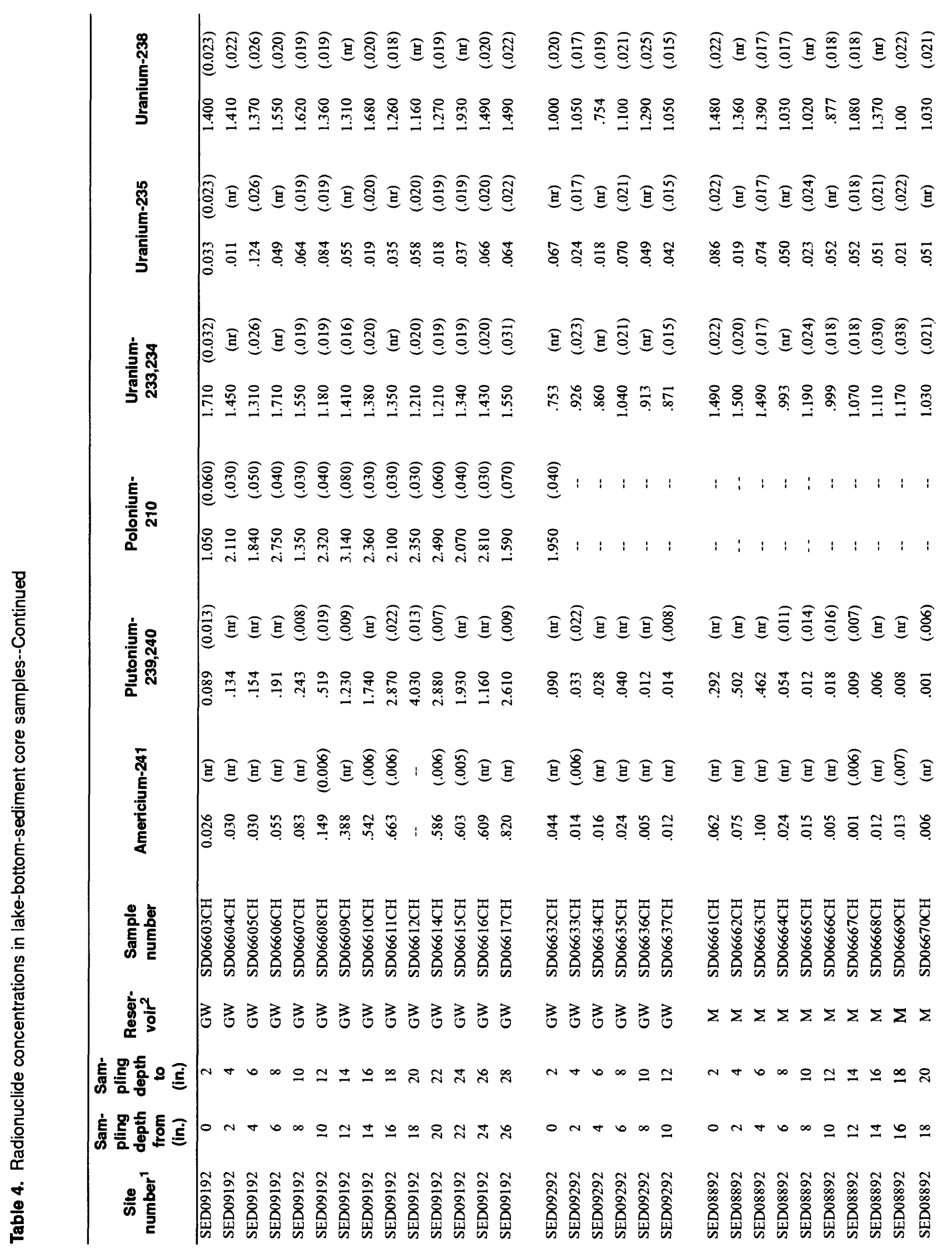




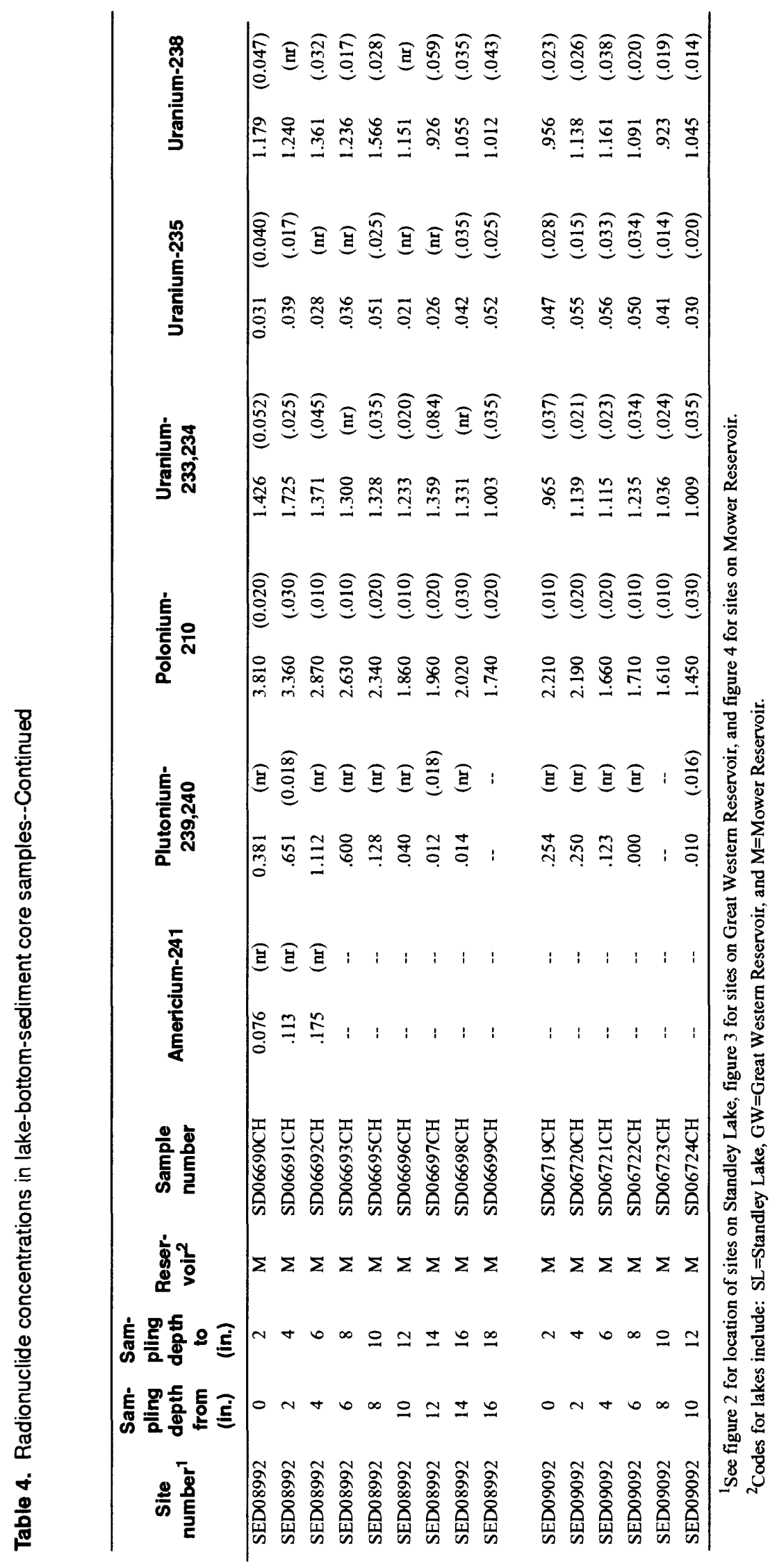




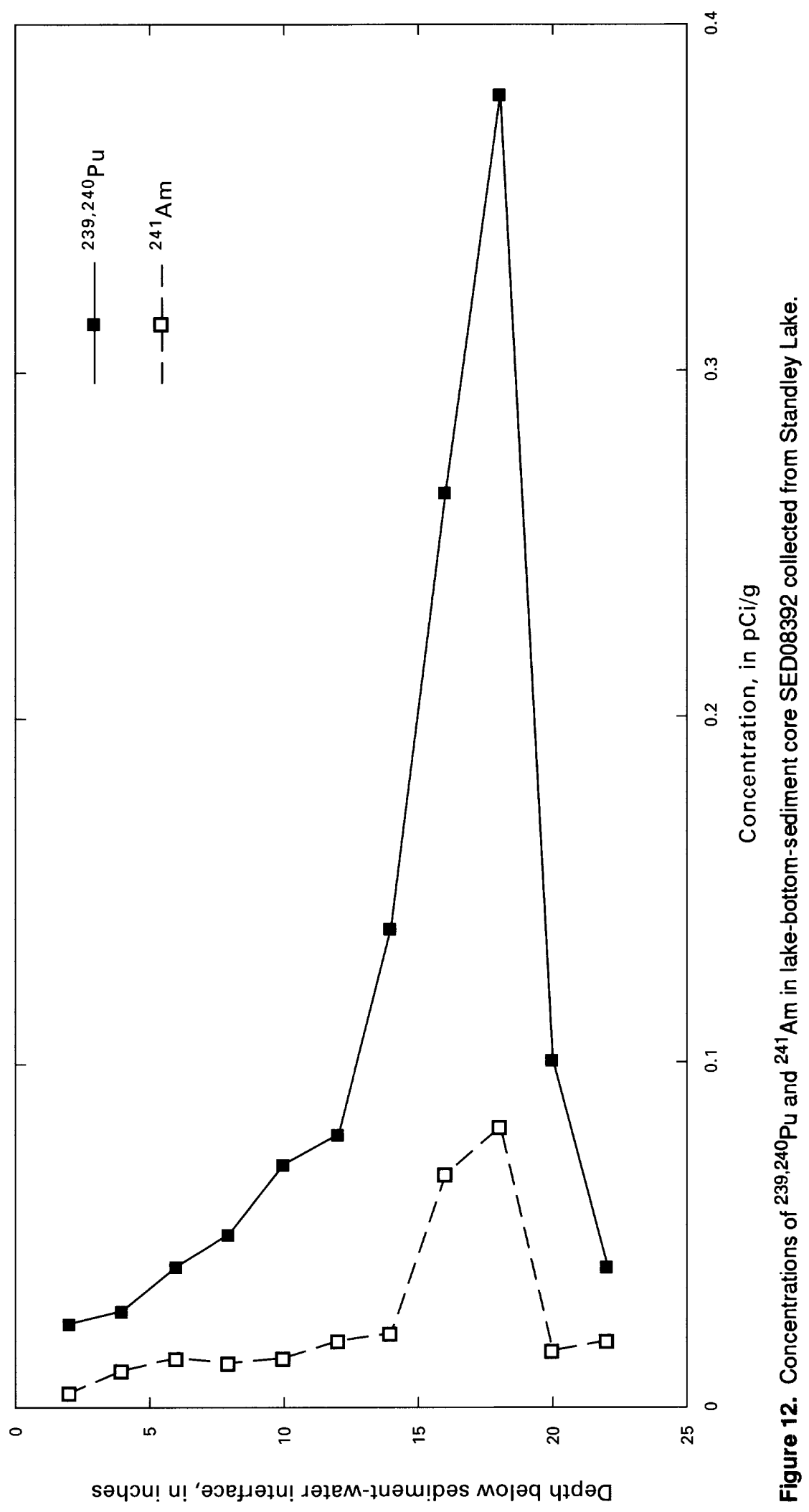




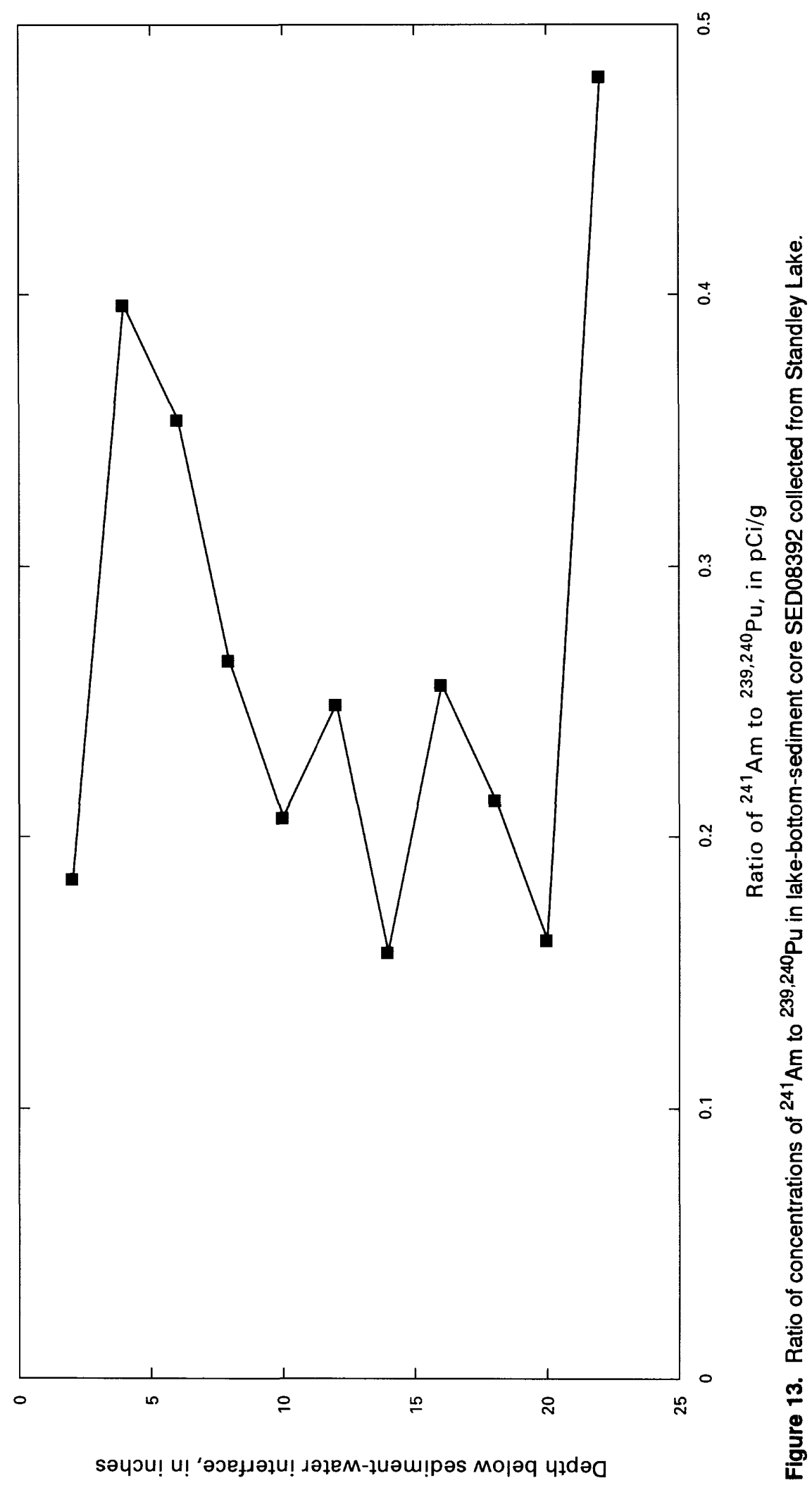
Mower Reservoir, Jefferson County, Colorado, 1992 
${ }^{239.240} \mathrm{Pu}$ concentration against ${ }^{241} \mathrm{Am}:{ }^{239,240} \mathrm{Pu}$ concentrations in lake-bottom-sediment cores collected from Standley Lake and Great Western Reservoir in 1992 indicates that there is no relation (fig. 14A). A relation was expected because the source of sediment that has high ${ }^{239,240} \mathrm{Pu}$ concentrations is likely to have been Rocky Flats debris, which has a relatively low ${ }^{241} \mathrm{Am}$ to ${ }^{239,240} \mathrm{Pu}$ ratio (Krey and others, 1976; Hardy and others, 1980). The reason for the lack of relation between ${ }^{239,240} \mathrm{Pu}$ concentration and ${ }^{241} \mathrm{Am}:{ }^{239,240} \mathrm{Pu}$ concentrations is unknown.

There is a linear relation $\left(r^{2}=0.986, p<0.02\right)$ between concentrations of ${ }^{239,240} \mathrm{Pu}$ and ${ }^{241} \mathrm{Am}$ (figure 14B). This result was expected because ${ }^{241} \mathrm{Am}$ is a decay product of ${ }^{241} \mathrm{Pu}$ (half-life $=14.4 \mathrm{yrs}$ ) and is useful as an indication of the validity of the analytical results.

\section{Comparison Between 1983 84 and 1992 Data}

In 1992, lake-bottom-sediment core samples were collected at four of the sites sampled in 1983-84. Two of these sites were in Standley Lake, and two were in Great Western Reservoir. At each lake, one site was in the deep part of the lake, and the other was in the middle or shallow part. For each coring location, data from 1983-84 and 1992 were matched after taking recent sedimentation into account, assuming a sedimentation rate of 1.2 to $1.5 \mathrm{in}$./yr in Standley Lake and 0.9 to $1.2 \mathrm{in} / \mathrm{yr}$ in Great Western Reservoir. A range of rates was used for each lake because sedimentation rates generally were higher in the deeper parts of the reservoirs than in the shallow parts (Cohen and others, 1990). Sedimentation rates were estimated based on matching of peaks and inflection points in plots of 239.240 $\mathrm{Pu}$ concentration against depth using 1983-84 and 1992 lake-bottom-sediment core data. The sedimentation rates used were reasonable based on rates reported by Hardy and others (1980), who estimated an average sedimentation rate of $1.3 \mathrm{in} / \mathrm{yr}$ for Standley Lake; sedimentation rates were unavailable for Great Western Reservoir.

Concentration of ${ }^{239,240} \mathrm{Pu}$ in sediment cores collected in 1983-84 and in 1992 is plotted with depth for each of the four sites in figures 15A through 15D. In general, trends in concentration to depth were consistent between 1983-84 and 1992 at all of the sites.

Boxplots of ${ }^{239,240} \mathrm{Pu}$ concentrations, and the differences between matched pairs of data, are shown in figure 16A. Measured concentrations tended to be somewhat higher in 1983-84 than in 1992. Although the median difference between the two data sets was statistically significant at $\mathrm{p}<0.05$, most differences between the matched pairs were small. The median difference was $0.050 \mathrm{pCi} / \mathrm{g}$, which is almost 100 times smaller (two orders of magnitude) than the peak $239,240 \mathrm{Pu}$ concentrations measured in this study. The mean difference was $0.200 \mathrm{pCi} / \mathrm{g}$. Differences in concentrations tended to increase at higher concentrations (fig. 16b). At ${ }^{239,240} \mathrm{Pu}$ concentrations between 1.5 and $5.5 \mathrm{pCi} / \mathrm{g}$, values from the 1992 study are 10 to 30 percent less than values reported in the 1983-84 study. The differences in measured concentrations may be attributable to spatial variations in sediment and 239,240 $\mathrm{Pu}$ deposition.

\section{Lake-Water Samples}

Summary statistics of dissolved and total radionuclide concentrations in lake-water samples are presented in table 5 . The median concentration of dissolved ${ }^{239,240} \mathrm{Pu}$ in lake water was 0.001 , and the maximum concentration was $0.009 \mathrm{pCi} / \mathrm{L}$ (table 5). Total ${ }^{239,240} \mathrm{Pu}$ concentrations in lake water were somewhat higher; the median concentration was $0.003 \mathrm{pCi} / \mathrm{L}$, and the maximum concentration was $0.030 \mathrm{pCi} / \mathrm{L}$. There are no National Drinking Water Standards for ${ }^{239,240} \mathrm{Pu}$, but the Colorado Department of Public Health and Environment has set a waterquality standard of $15 \mathrm{pCi} / \mathrm{L}$ and a site-specific waterquality standard of $0.030 \mathrm{pCi} / \mathrm{L}$ for Standley Lake and Great Western Reservoir (Colorado codes and regulations, 3.8.0, 5CCR 102-8). ${ }^{239,240} \mathrm{Pu}$ and ${ }^{241} \mathrm{Am}$ are alpha emitters that contribute to the gross alpha concentrations in lake water in Standley Lake, Great Western Reservoir, and Mower Reservoir. The median dissolved gross alpha concentration was $0.52 \mathrm{pCi} / \mathrm{L}$, and the maximum was $1.9 \mathrm{pCi} / \mathrm{L}$ (table 5). These concentrations are substantially below the National Drinking Water Standard for gross alpha concentration of $15 \mathrm{pCi} / \mathrm{L}$ (U.S. Environmental Protection Agency, 1995). Uranium concentrations also were well below the National Drinking Water Standard of $15 \mathrm{pCi} / \mathrm{L}$ (U.S. Environmental Protection Agency, 1995); the median dissolved concentrations for ${ }^{233,234} \mathrm{U},{ }^{235} \mathrm{U}$, and ${ }^{238} \mathrm{U}$ were $0.500,0.024$, and $0.270 \mathrm{pCi} / \mathrm{L}$, and maximum dissolved concentrations were $1.2,0.71$ and $0.73 \mathrm{pCi} / \mathrm{L}$ (table 5). The maximum dissolved ${ }^{241} \mathrm{Am}$ concentration was $0.116 \mathrm{pCi} / \mathrm{L}$, and the maximum total ${ }^{241} \mathrm{Am}$ concentration was $0.026 \mathrm{pCi} / \mathrm{L}$. The maximum total tritium concentration was $144.3 \mathrm{pCi} / \mathrm{L}$ (dissolved tritium was not measured). National Drinking Water Standards for ${ }^{241} \mathrm{Am}$ and tritium do not exist. In summary, concentrations of all radionuclides measured in lake water at Standley Lake, Great Western Reservoir, and Mower Reservoir were below National Drinking Water Standards for constituents where standards exist. 


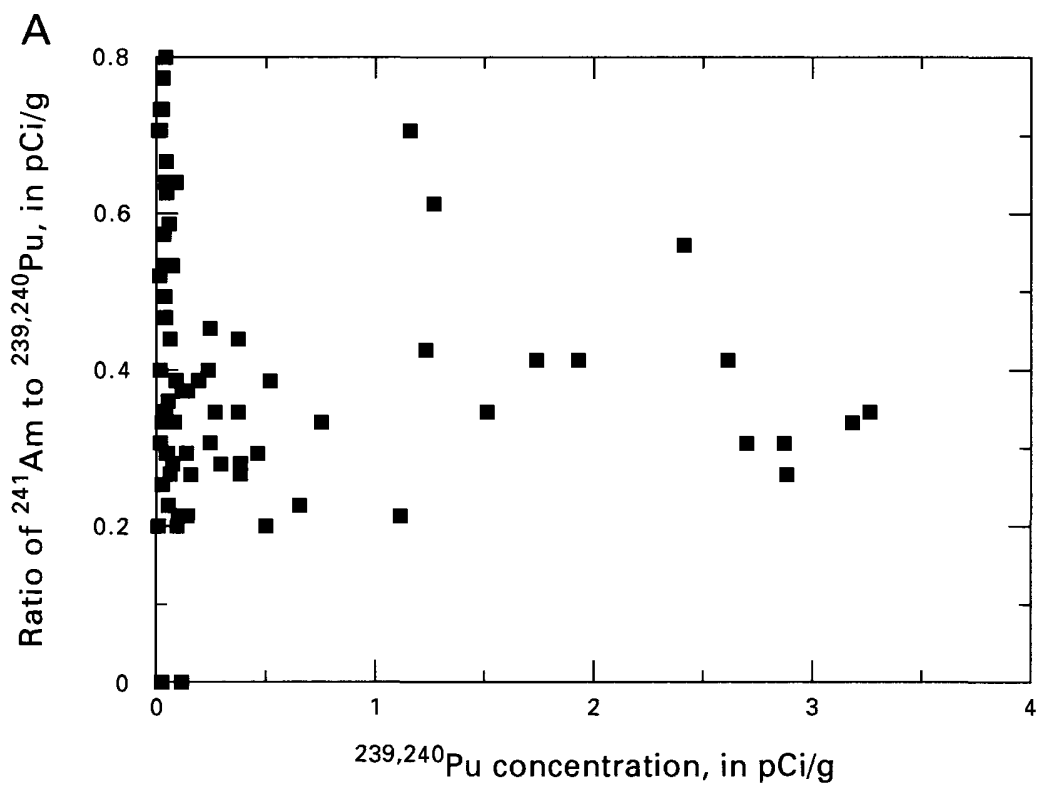

Figure 14A. Relation between ${ }^{241} \mathrm{Am}$ to ${ }^{239,240} \mathrm{Pu}$ concentration ratio and 239,240 Pu concentration in lake-bottom-sediment core samples collected from Standley Lake and Great Western Reservoir.

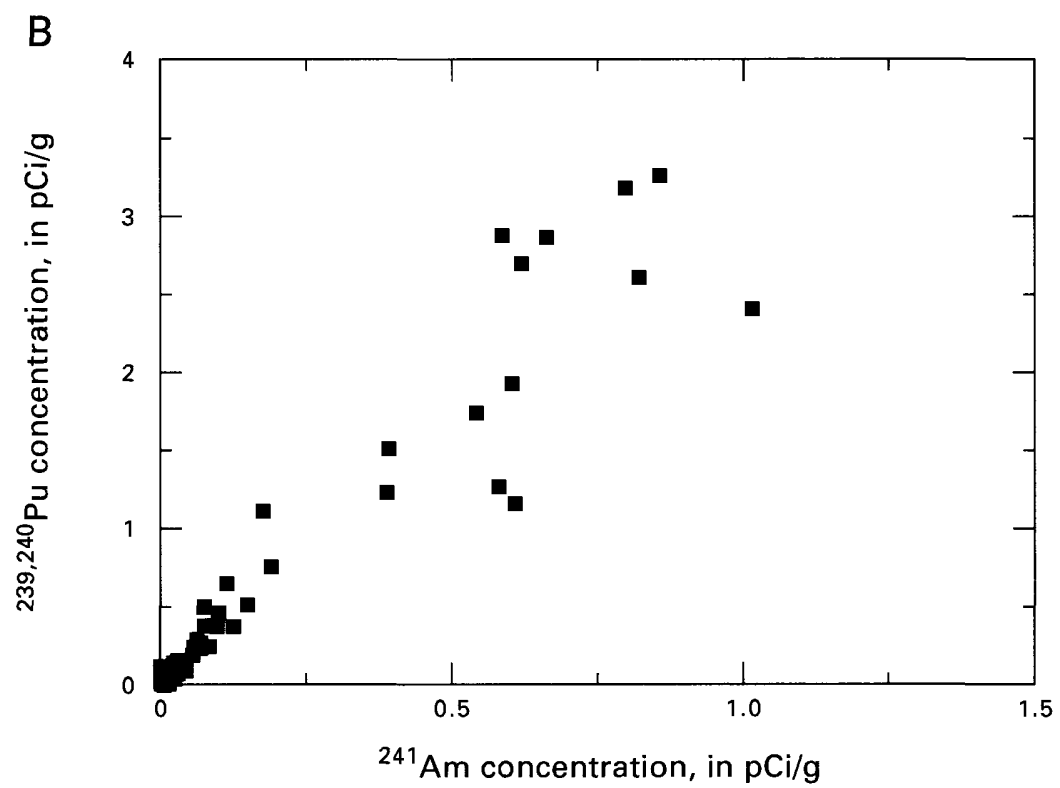

Figure 14B. Relation between concentrations of ${ }^{239,240} \mathrm{Pu}$ and ${ }^{241} \mathrm{Am}$ in lake-bottom-sediment core samples collected from Standley Lake and Great Western Reservoir. 


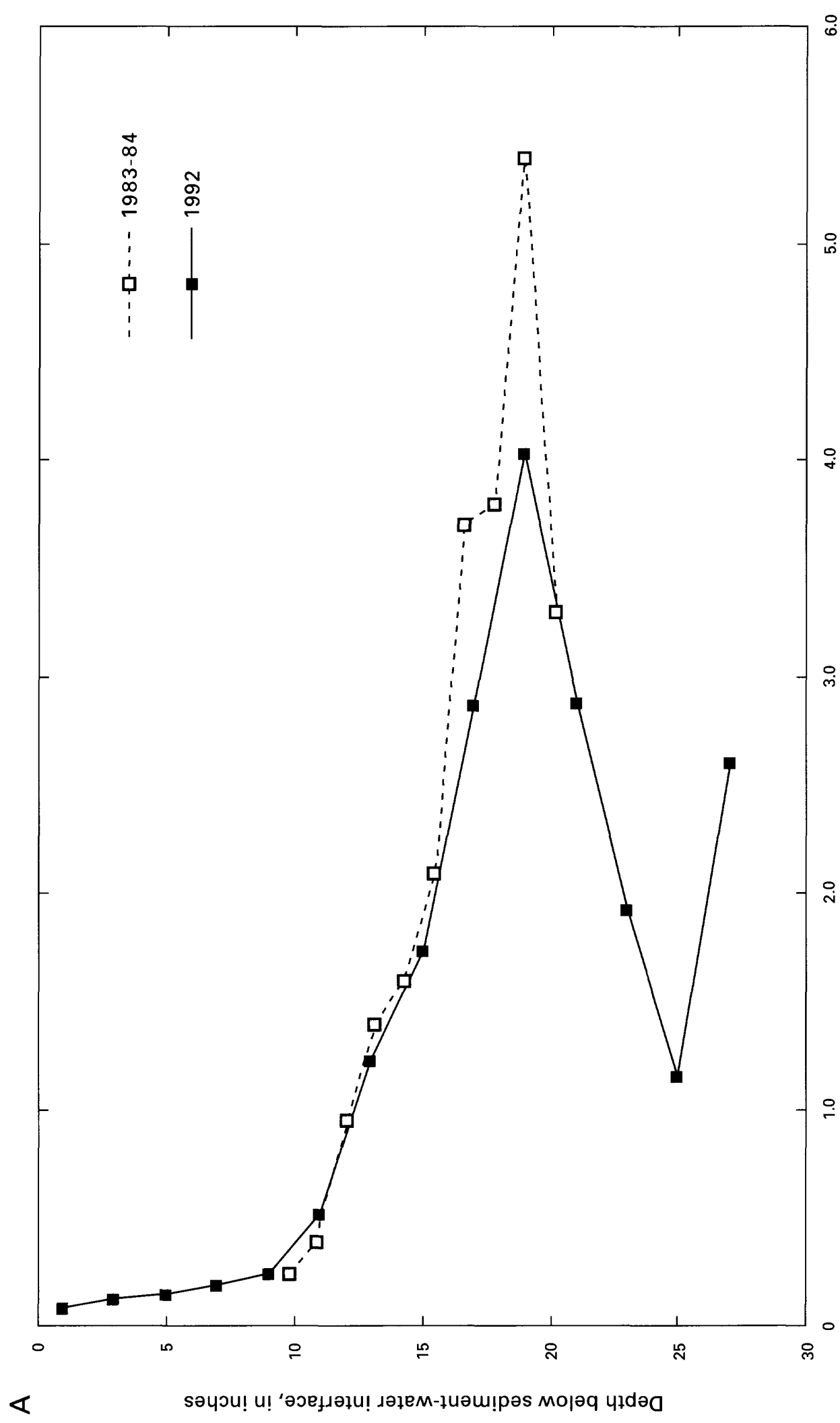




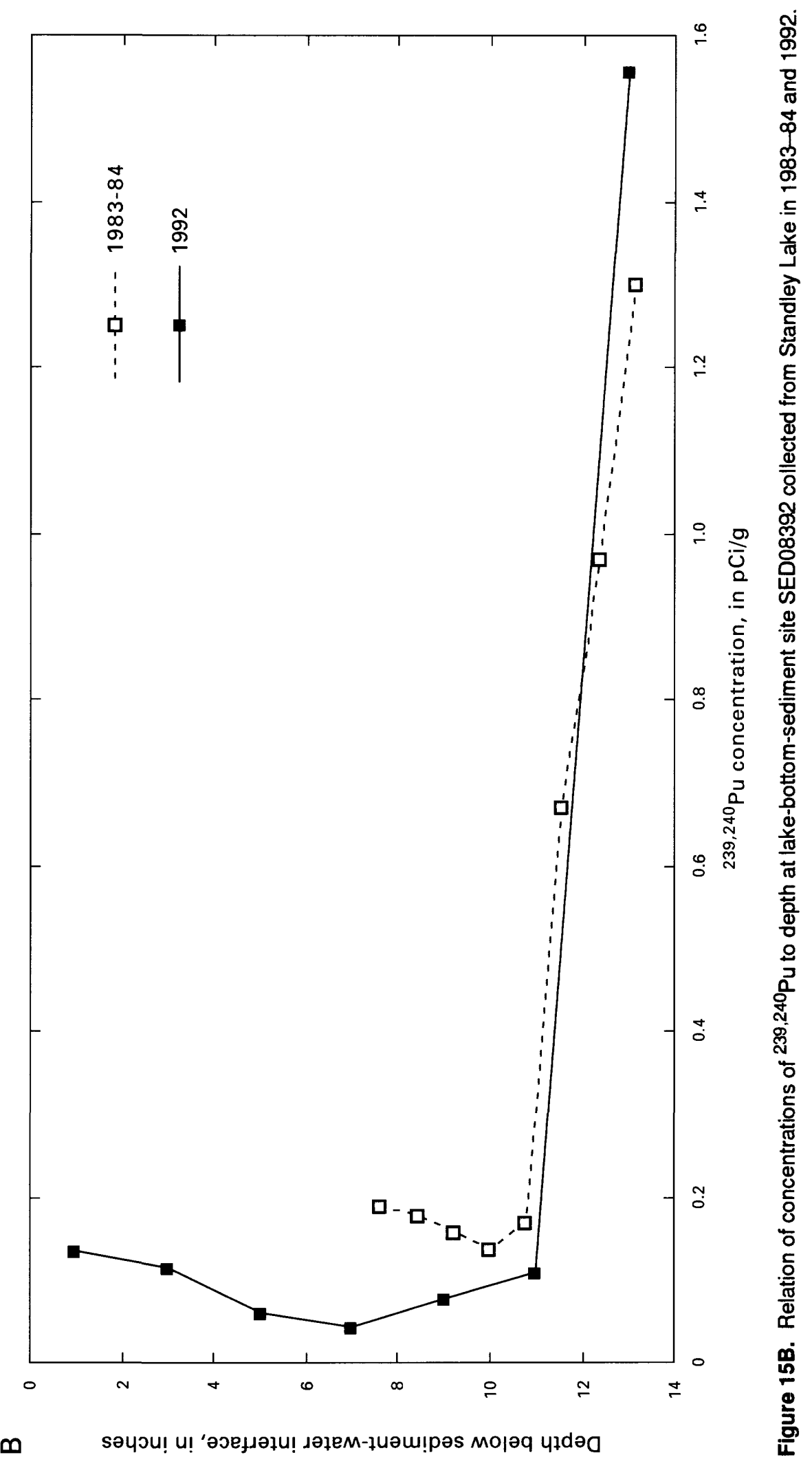

28 Characterization of Selected Radionuclides in Sediment and Surface Water in Standley Lake, Great Western Reservoir, and Mower Reservolr, Jefferson County, Colorado, 1992 


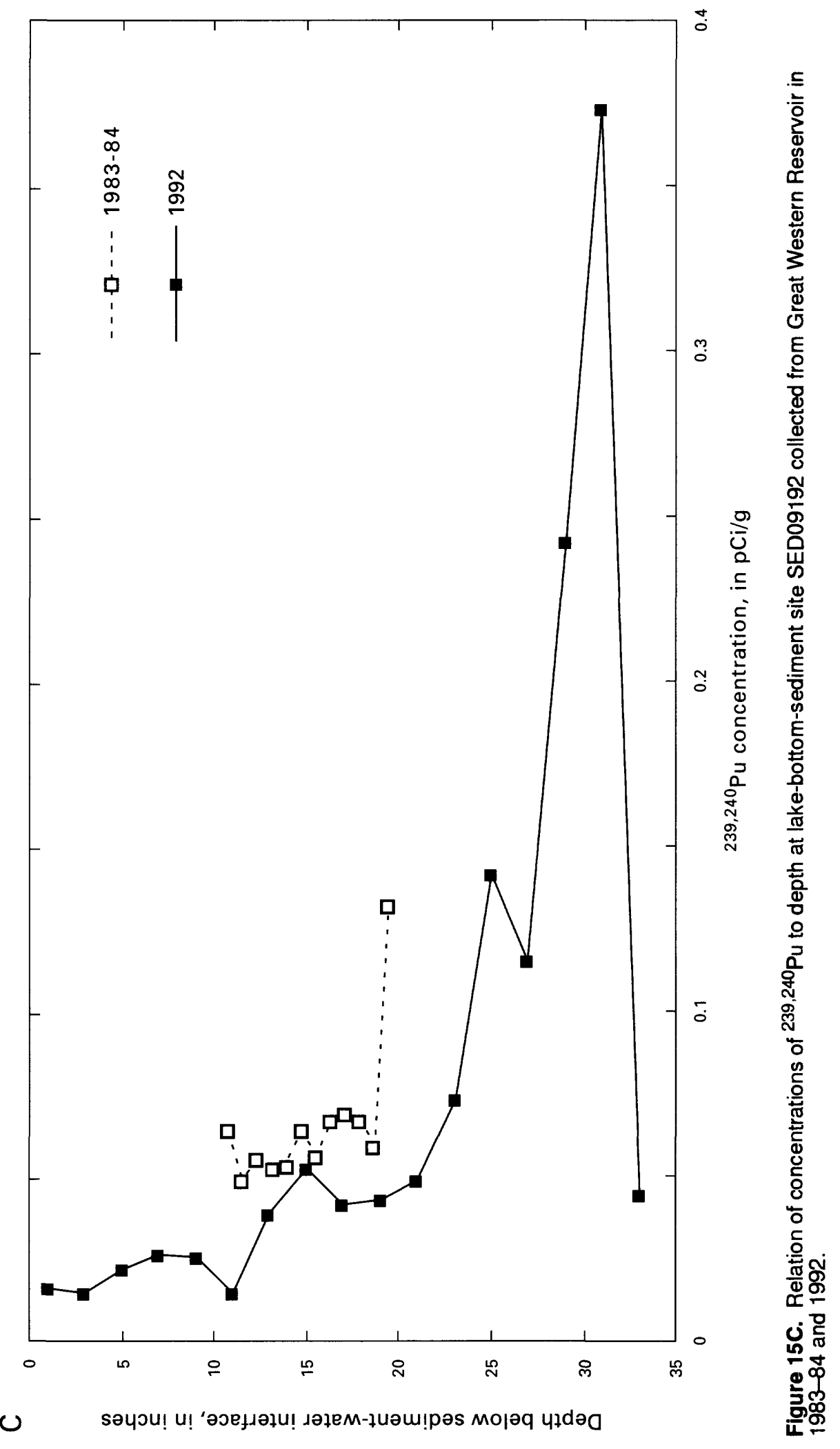




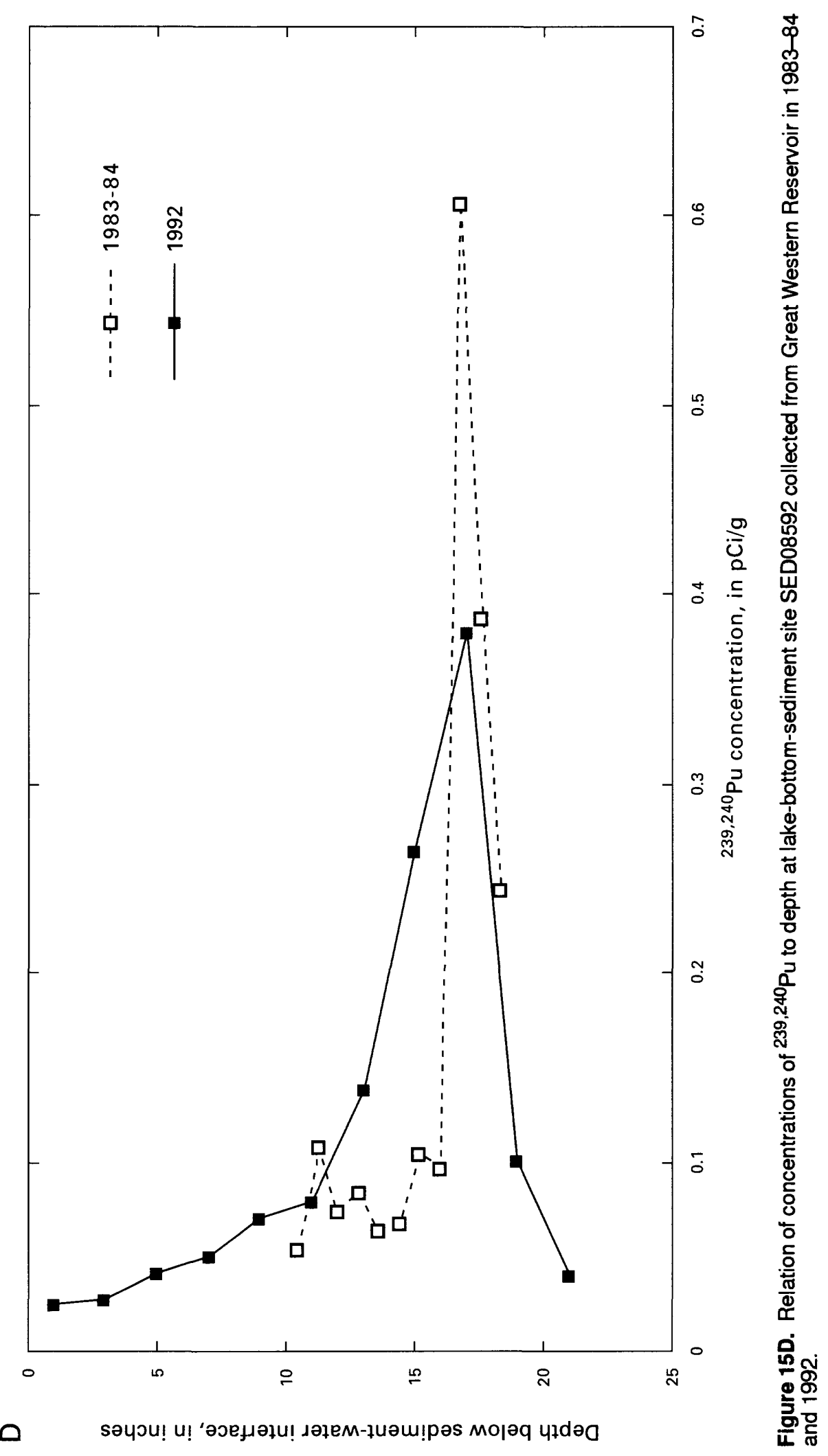




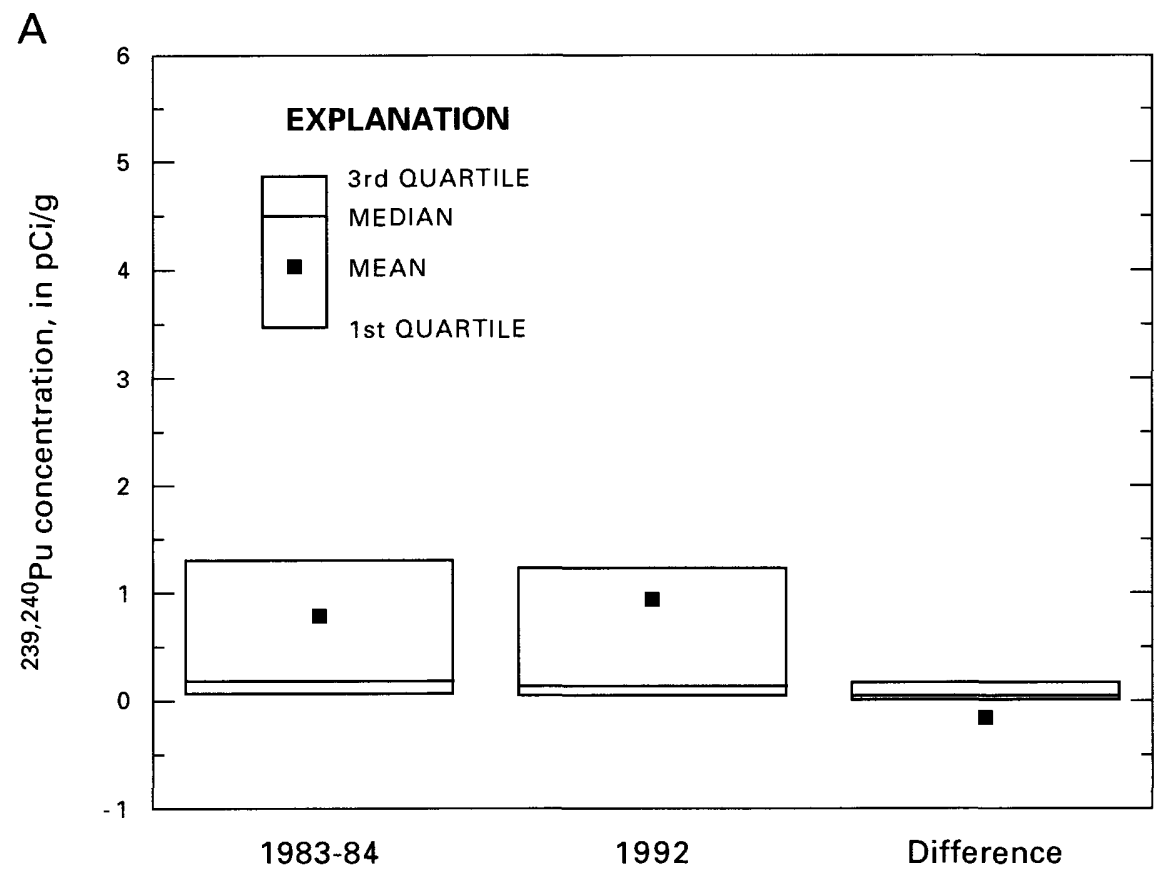

Figure 16A. Distribution of concentrations of ${ }^{239,240} \mathrm{Pu}$ in lake-bottom-sediment core samples collected from Standley Lake and Great Western Reservoir.

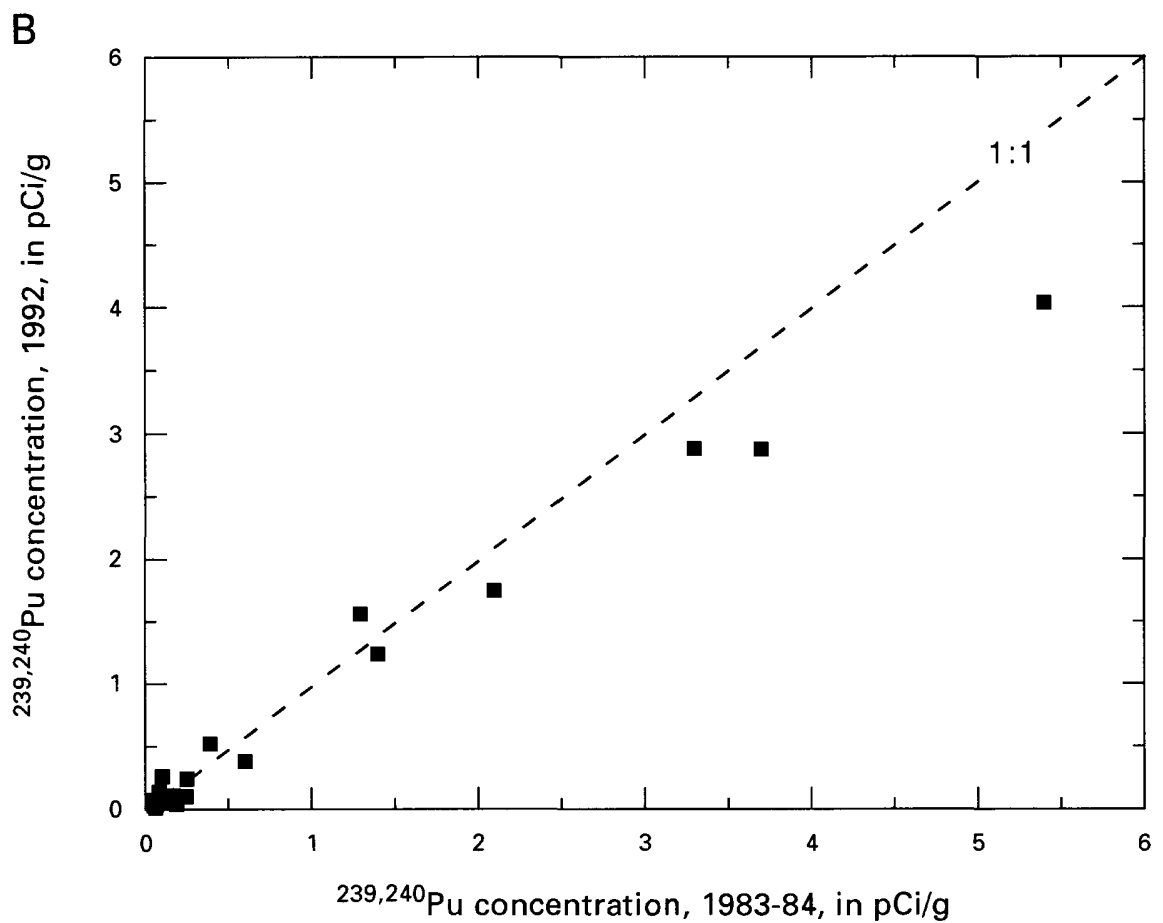

Figure 16B. Relation between ${ }^{239,240} \mathrm{Pu}$ concentrations in lake-bottom-sediment core samples collected from Standley Lake and Great Western Reservoir in 1983-84 and 1992 . 


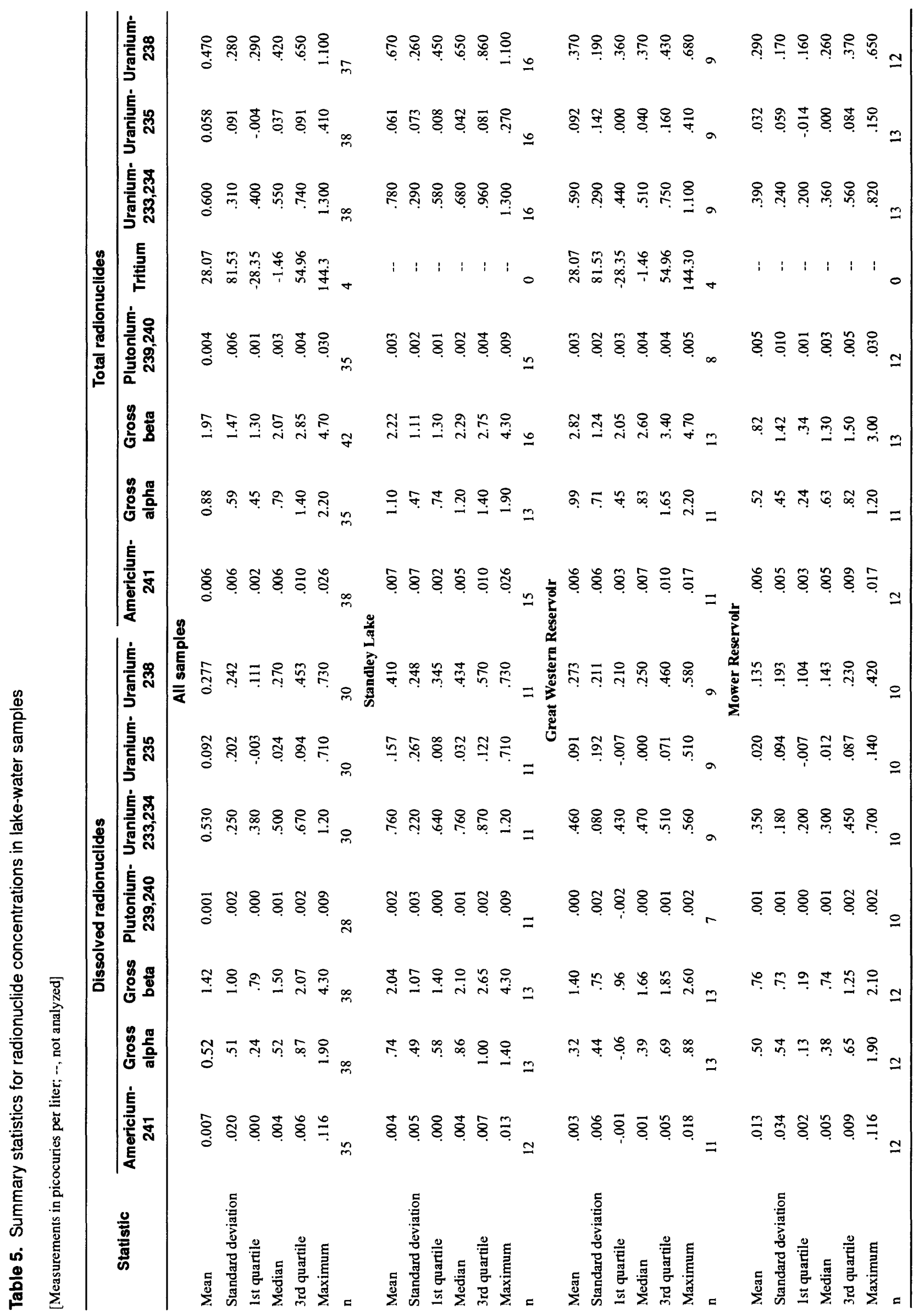


There were no statistically significant differences in ${ }^{239,240} \mathrm{Pu}$ concentrations in surface water collected at the three study lakes in 1992. However, gross alpha and uranium isotope concentrations tended to be higher in Standley Lake than in the other reservoirs; gross alpha concentrations were higher in Standley
Lake than in Great Western Reservoir ( $p<0.05)$ (figs. 17 and 18, table 5). Uranium-233,234 concentrations were higher in Standley Lake than in Mower Reservoir, and uranium-238 concentrations were higher in Standley Lake than in Great Western and Mower Reservoirs $(p<0.05)$. The relatively high concentrations of ura-

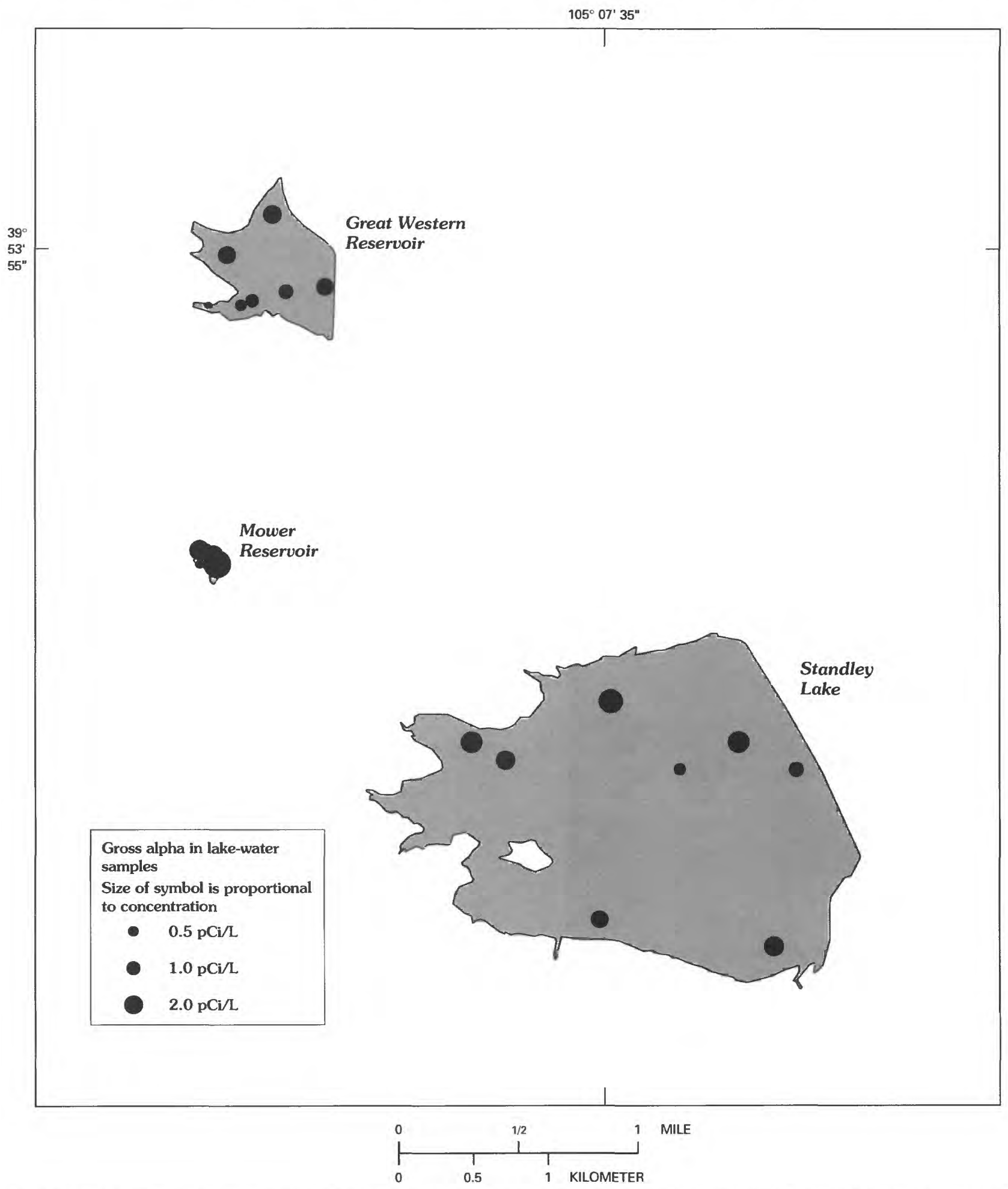

Figure 17. Gross alpha concentrations in water samples collected in 1992 from Standley Lake, Great Western Reservoir, and Mower Reservoir. 


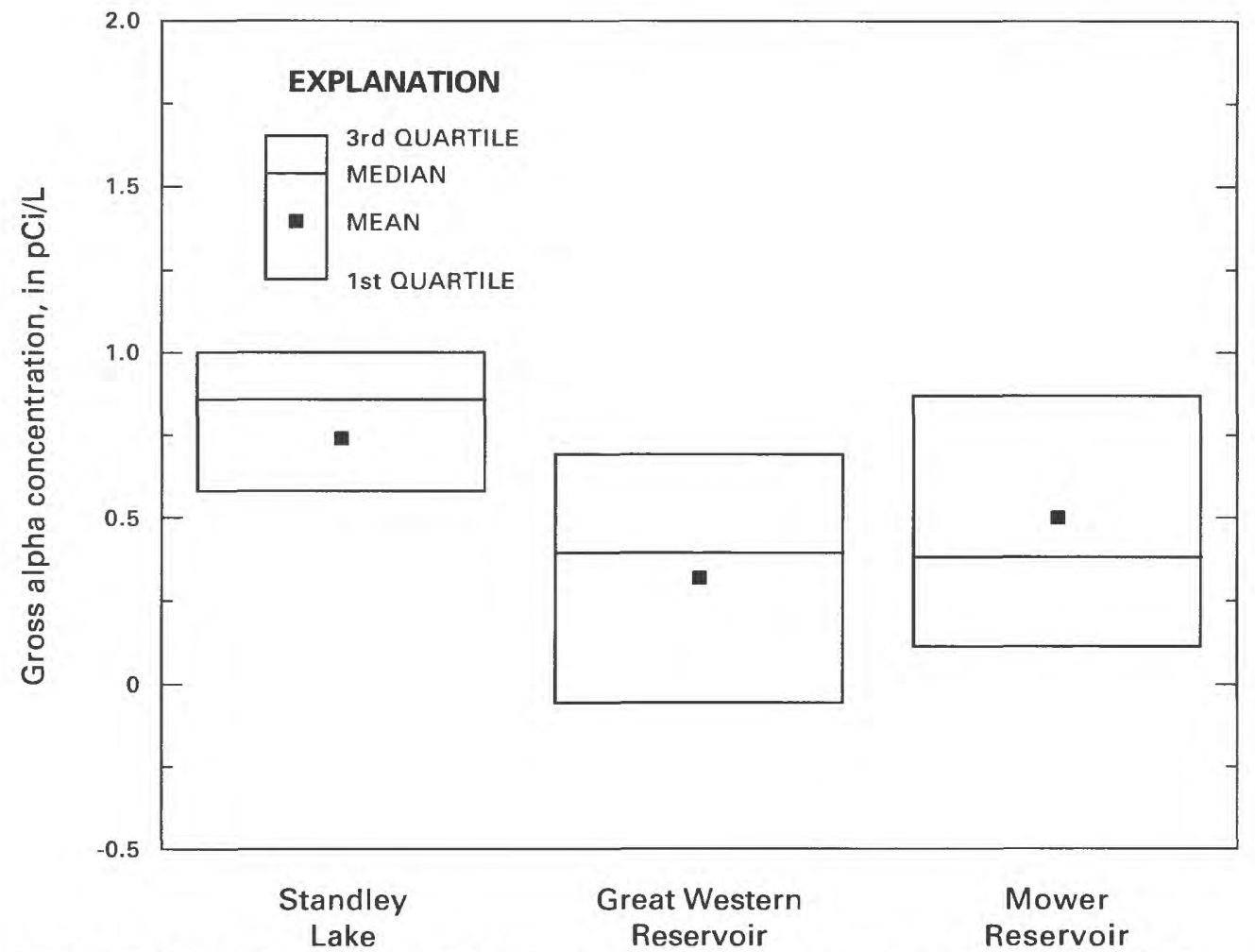

Figure 18. Distribution of gross alpha concentrations in water samples collected in 1992 at Standley Lake, Great Western Reservoir, and Mower Reservoir.

nium in Standley Lake may be due to weathering of marine shales that contain substantial amounts of uranium. In southeastern Colorado, uranium concentrations in the Arkansas River have been found to increase markedly where the river crosses from a predominantly igneous and metamorphic terrain into areas where marine shale and limestone are the dominant bedrock types (Zielinski and others, 1995). Shale bedrock that crops out to the west of Standley Lake contains substantial quantities of uranium and, thus, may provide a source of uranium to streams that flow into Standley Lake.

\section{SUMMARY}

Median ${ }^{239,240} \mathrm{Pu}$ concentrations in lakesediment grab samples from Standley Lake, Great Western Reservoir, and Mower Reservoir were 0.037 , 0.105 , and $0.351 \mathrm{pCi} / \mathrm{g}$, and the differences between the reservoirs were statistically significant at $p<0.05$. The spatial pattern of ${ }^{239,240} \mathrm{Pu}$ concentration identified in this study, i.e., sediment in lakes closest to Rocky Flats Environmental Technology Site having the highest ${ }^{239,240} \mathrm{Pu}$ concentrations, is consistent with ${ }^{239,240} \mathrm{Pu}$ concentration patterns previously measured in soil surrounding Rocky Flats.
Maximum concentrations of ${ }^{239,240} \mathrm{Pu}$ dissolved in lake water were $0.009 \mathrm{pCi} / \mathrm{L}$, well below limits suggested by the Colorado Department of Public Health and Environment. Dissolved concentrations of gross alpha and ${ }^{233,234} \mathrm{U},{ }^{235} \mathrm{U}$, and ${ }^{238} \mathrm{U}$ were below National Drinking Water Standards in all water samples. There were no statistically significant differences in ${ }^{239,240} \mathrm{Pu}$ concentrations in surface water collected at the three study lakes in 1992.

A comparison of ${ }^{239,240} \mathrm{Pu}$ concentrations in lake-sediment grab samples collected from Standley Lake and Great Western Reservoir in 1983-84 to concentrations in 1992 revealed no statistically significant difference $(p<0.05)$ in mean values when samples from the lakes were grouped. When samples from each lake were considered separately, and data from the two studies were compared, it was determined that there was a small, but statistically significant, difference in 239,240 $\mathrm{Pu}$ concentrations at Great Western Reservoir $(p<0.05)$; concentrations were lower in 1992. The most likely reason for the difference is that sediments deposited in Great Western Reservoir in the 1960's and 70's have been buried beneath newer sediment with lower concentrations of ${ }^{239,240} \mathrm{Pu}$. The technique used to obtain grab sediment samples collects sediment from 
only the upper $2-4$ in. of sediments; thus, it is possible that only newer, relatively uncontaminated, sediments were sampled in 1992.

Trends in ${ }^{239,240} \mathrm{Pu}$ concentrations with depth identified in the 1992 study were similar to trends observed in the 1983-84 study and other previous studies. In the 1992 investigation, maximum ${ }^{239,240} \mathrm{Pu}$ concentrations occurred at depths ranging from 13 to 31 in. below the sediment-water interface at most sites. There was a small, but statistically significant, difference ( $p<0.05$ ) in median ${ }^{239,240} \mathrm{Pu}$ concentrations in co-located lake-bottom-sediment cores collected in 1983-84 and in 1992. The median difference between data sets was $0.050 \mathrm{pCi} / \mathrm{g}$, and differences tended to increase with concentration; in samples with concentrations above $1.5 \mathrm{pCi} / \mathrm{L}$, concentrations were 10 to 30 percent higher in 1983-84 than in 1992. The differences in concentrations could be attributable to spatial variations in sediment and ${ }^{239,240} \mathrm{Pu}$ deposition.

\section{REFERENCES CITED}

Buchanan, T.J., and Somers, W.P., 1980, Discharge measurements at gaging stations: U.S. Geological Survey Techniques of Water-Resources Investigations, book 3, chap. A8, 65 p.

Cohen, R.R., Gilbert, D.M., and Wolaver, H.A., 1990, ${ }^{239,240} \mathrm{Pu},{ }^{137} \mathrm{Cs}$ and ${ }^{210} \mathrm{~Pb}$ distributions in Colorado Front Range lake sediments-A report to the Rocky Flats Plant, Rockwell International, and EG\&G: Golden, Colorado School of Mines.

EG\&G Rocky Flats, Inc., 1991, Standard operating procedures: Golden, Colo., Rocky Flats Environmental Monitoring and Assessment Division, $4 \mathrm{v}$.

Gilliom, R.J., Hirsch, R.M., and Gilroy, E.J., 1984, Effect of censoring trace-level water-quality data on trenddetection capability: Environ. Sci. Technol., v. 18, no. 7, pp. 530-535.

Hardy, E.P., Volchok, H.L., Livingston, H.D., and Burke, J.C., 1980, Time pattern of off-site plutonium deposition from Rocky Flats Plant by lake sediment analyses: Environment International, v. 4, no. 1, pp. 21-30.

Helsel, D.R., and Hirsh, R.M., 1992, Statistical methods in water resources: Amsterdam, Elsevier, Studies in Environmental Science 49, 522 p.

Krey, P.W., and Hardy, E.P., 1970, Plutonium in soil around the Rocky Flats Plant: New York, NY., U.S. Atomic Energy Commission Report HASL-235

Krey, P.W., Hardy, E.P., Volchok, H.L., Toonkel, L.E., Knuth, R.H., Coppes, M., and Tamura, T., 1976, Plutonium and americium contamination in Rocky Flats soil,
1973: U.S. Energy Research and Development Administration Report HASL-304.

Litoar, M.I., Thompson, M.L., Barth, G.R., and Molzer, P.C., 1994, Plutonium-239 + 240 and americium-241 in soils east of Rocky Flats, Colorado: J. Environ. Qual., v. 23, pp. 1231-1239.

Livingston, H.D., and Bowen, V., 1976, Americium in the marine environment-relationships to plutonium, in Environmental Toxicity of Aquatic Radionuclides: Models and Mechanisms, Ann Arbor Science, Ann Arbor, MI, pp. 107-130.

Ott, R.L., 1993, An introduction to statistical methods and data analysis (4th ed.): Duxbury Press, $1051 \mathrm{p}$.

Porter, P.S., Ward, R.C., and Bell, H.F., 1988, The detection limit: Environ. Sci. Technol., v. 22, no. 8, pp. 856-861.

Ruddy, B.C., Johncox, D.A., and Mueller, D.K., 1992, Methods of data collection and water-quality data for Standley Lake, Jefferson County, Colorado, 1989-90: U.S. Geological Survey Open-File Report 92-44, 186 p.

Sackschewsky, V.E., 1985, Analysis of Great Western Reservoir plutonium concentration data-Internal document: Rocky Flats, Scientific Applications Information Systems Management, Internal Document, February 13, 1986, $21 \mathrm{p}$.

Setlock, G.H., 1983, Great Western Reservoir Study-Internal document: Rocky Flats, Rockwell International, Health, Safety and Environment, Environmental Analysis and Control, 16 p.

Setlock, G.H., and Paricio, M.L., 1984, Standley Lake sediment sample collection summary, August, 1984Internal document: Rocky Flats, Rockwell International, Health, Safety and Environment, Environmental Analysis and Control, $11 \mathrm{p}$.

Thomas, C.W., and Robertson, D.E., 1981, Radionuclide concentrations in reservoirs, streams, and domestic waters near the Rocky Flats Installation: Battelle Pacific Northwest Laboratory, Report PNL-2919, UC-11, April 1981.

U.S. Department of Energy, 1990, General radiochemistry and routine analytical services protocol (GRRASP), Rocky Flats Plant: Golden, Colo. 1992, RFI/RI final work plan for operable unit 3: Golden, Colo., Rocky Flats Plant, Environmental Restoration Program. 1994, Rocky Flats Plant site-wide quality-assurance project plan for CERCLA remedial investigations/ feasibility studies and RCRA facility investigations/ corrective measures studies activities.

U.S. Environmental Protection Agency, 1973, Radioactivity levels in the environs of the Rocky Flats Plutonium Plant, Colorado: Denver, U.S. Environmental Protection Agency Report SA/TIB-29. 
1975, Plutonium levels in the sediments of area impoundments, environs of the Rocky Flats Plutonium Plant, Colorado: Denver, U.S. Environmental Protection Agency Report SA/TIB-29.

1995, Drinking water regulations and health advisories: Washington, D.C., Code of Federal Regulations,

Title 40, Part 141. (May 1995.)

Walker, F.W., Parrington, J.R., and Feiner, F., 1989, Nuclides and isotopes (14th ed.), San Jose, Calif., General Electric Company, $57 \mathrm{p}$.

Zielinski, R.A., Asher-Bolinder, S., and Meier, A.L., 1995, Uraniferous waters of the Arkansas River valley,

Colorado, U.S.A.-A function of geology and land use: Applied Geochemistry., v. 10, p. 133-144. 
APPENDIXES 

APPENDIX A

Lake-sediment grab samples

APPENDIX A 39 


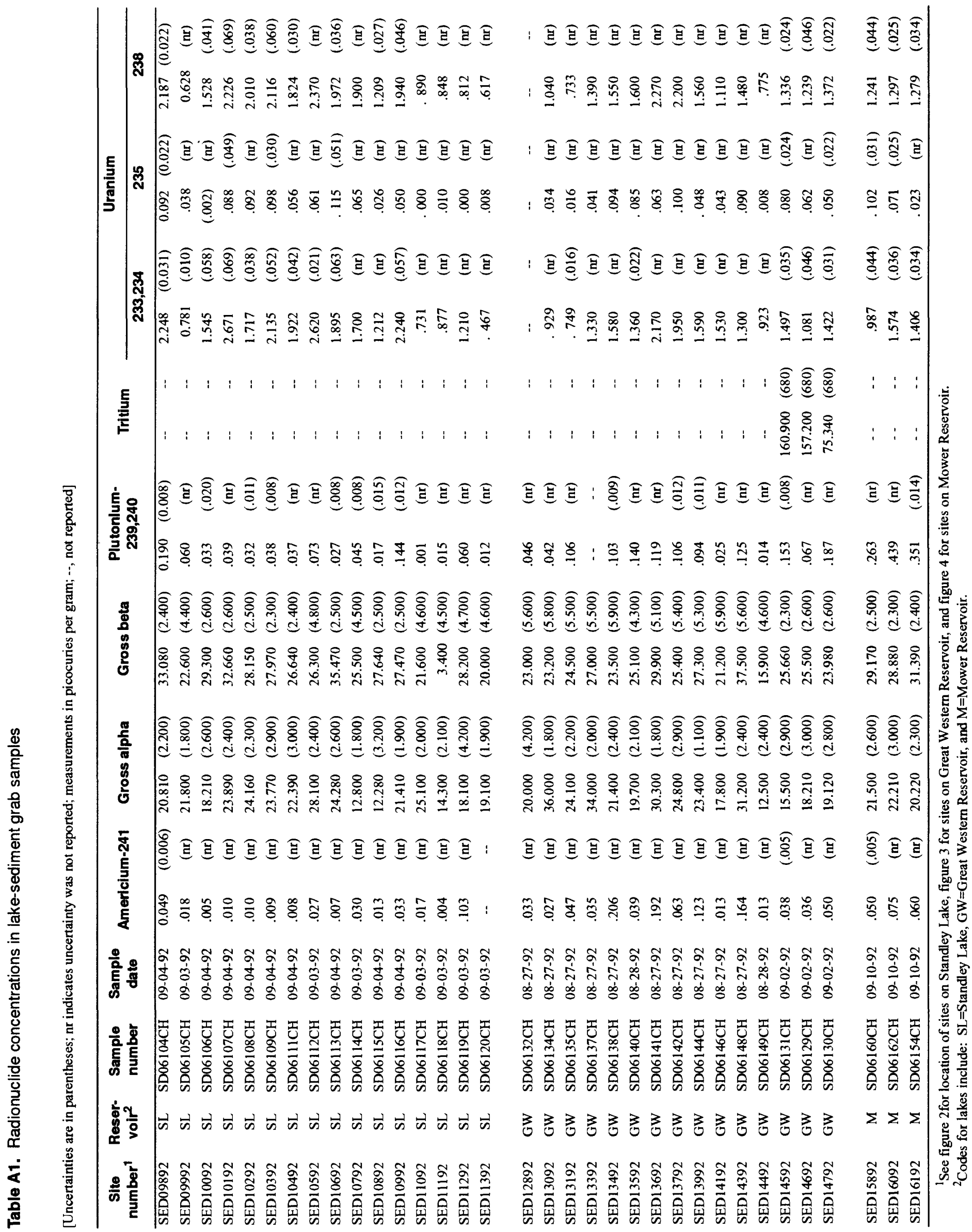

40 Characterization of Selected Radionuclides in Sediment and Surface Water in Standley Lake, Great Western Reservolr, and Mower Reservoir, Jefferson County, Colorado, 1992 


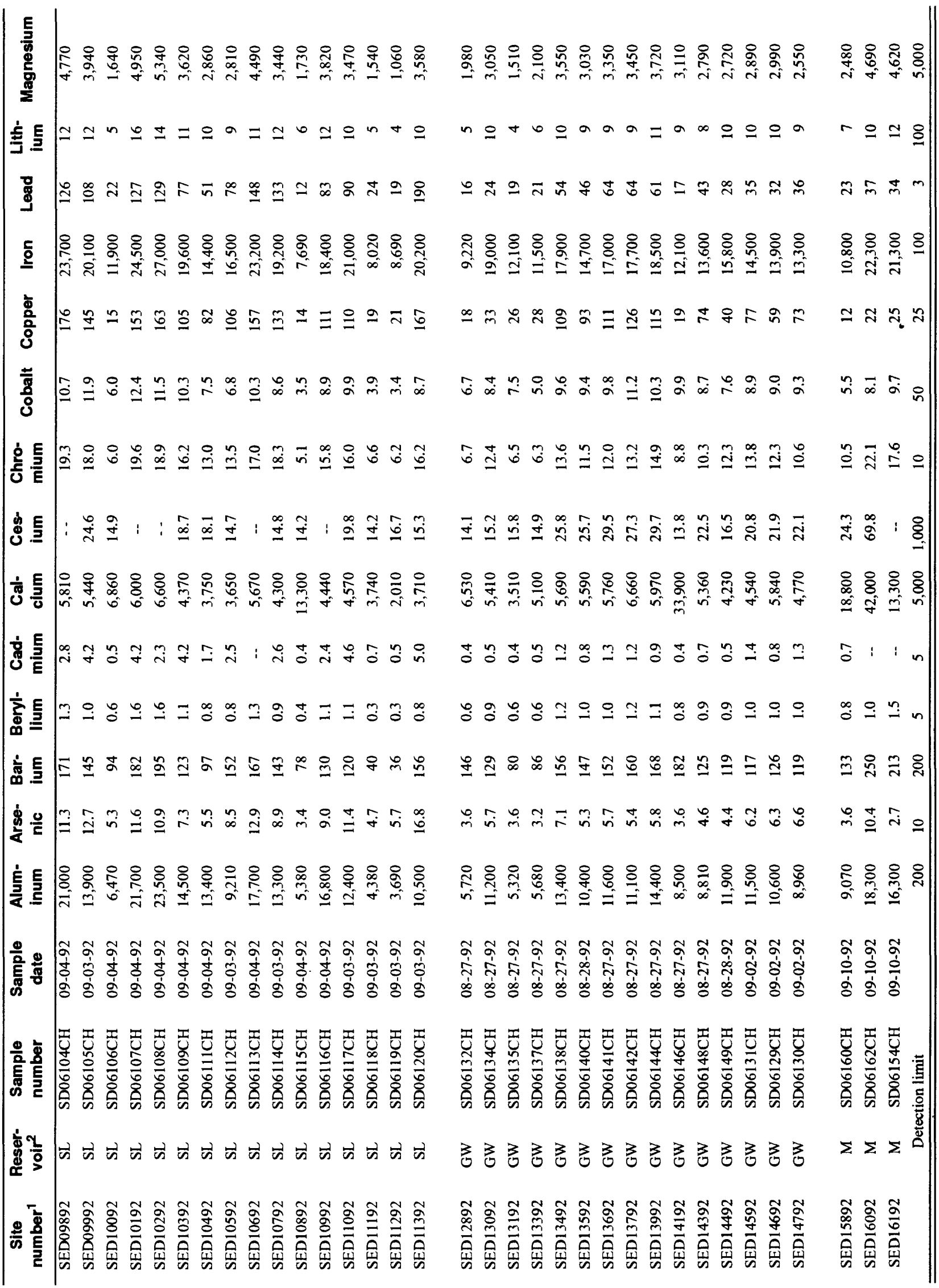




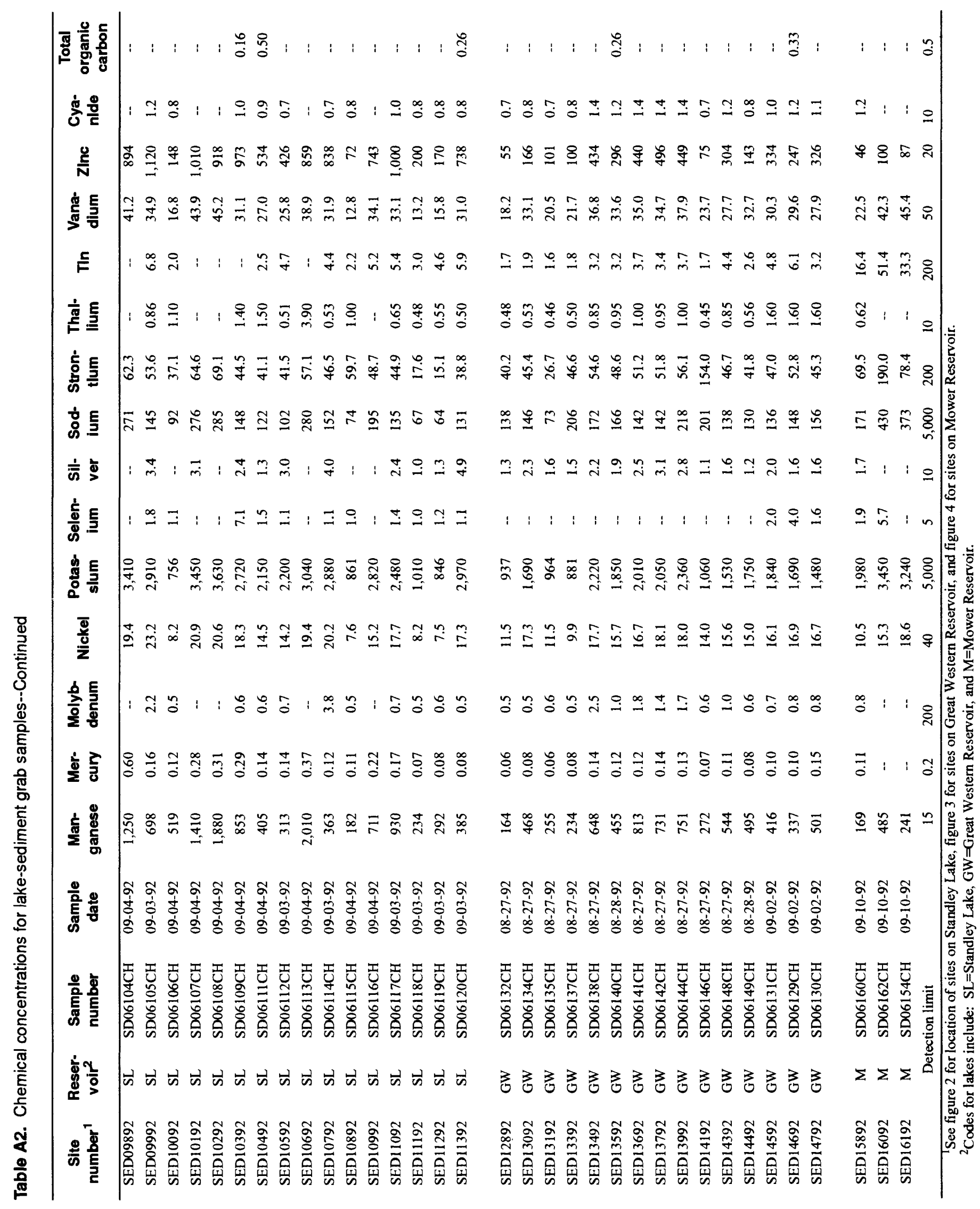

42 Characterization of Selected Radionuclides in Sediment and Surface Water in Standley Lake, Great Western Reservoir, and Mower Reservoir, Jefferson County, Colorado, 1992 
APPENDIX B

Lake-bottom-sediment core samples 
Table B1. Lake-bottom-sediment core descriptions

[in., inches]

\begin{tabular}{|c|c|c|c|}
\hline $\begin{array}{l}\text { Depth from } \\
\text { top } \\
\text { (in.) }\end{array}$ & Color & Texture & Other features/observations \\
\hline
\end{tabular}

Standley Lake (Site ID: SED08192) September 8, 1992

$\begin{array}{cl}0-0.50 & \text { Olive } \\ 0.50-3.5 & \text { Olive gray } \\ 3.5-6.0 & \text { Dark olive gray } \\ 6.0-8.0 & \text { Olive gray } \\ 8.0-9.0 & \text { Dark gray } \\ 9.0-14.0 & \text { Olive gray } \\ 14.0-17.0 & \text { Olive gray } \\ 17.0-19.0 & \text { Black } \\ 19.0-22.5 & \text { Olive gray } \\ 22.5-25.0 & \text { Dark olive gray } \\ 25.0-26.5 & \text { Olive gray } \\ 26.5-28.5 & \text { Dark olive gray } \\ 28.5-30.5 & \text { Olive gray } \\ 30.5-35.0 & \text { Dark olive gray } \\ 35.0-36.0 & \text { Black }\end{array}$

Silt Abundant fine-grained organic particles, wet

Clayey silt Very wet, fine-grained organic particles

Clayey silt Roots, stems, slight $\mathrm{H}_{2} \mathrm{~S}$ odor, wet

Clayey silt Less organics, no roots/stems, wet

Silty clay Wet, some stems

Silty clay Abundant root hairs, stems, organic particles, wet

Silty clay Root hairs, stems, fine-grained organic, wet

Clay Drier, root hairs

Clay Mottled, $\mathrm{H}_{2} \mathrm{~S}$ odor, root hairs

Clay Stems, root hairs (long strands)

Sand (silty) Very coarse, stem and bark pieces

Silty clay Coarse root, stems, root hairs

Silty clay Finer root hairs, no stems, drier

Clay Drier, few root hairs, some grass

Clay Very few organics, slight $\mathrm{H}_{2} \mathrm{~S}$ odor

Olive gray

Olive

$9.0-12.0$

Very dark gray

$12.0-15.5$

Dark olive gray

15.5-22.0

Black

22.0-22.5

Olive gray

Olive gray

Silt
Silt
Silt
Clayey silt
Clayey silt
Clayey silt
Clay
Clay

Standley Lake (Site ID: SED08392)

September 8, 1992

Very wet, fine-grained organics

Strong $\mathrm{H}_{2} \mathrm{~S}$ odor, very wet

Strong $\mathrm{H}_{2} \mathrm{~S}$, more fine-grained organics

Strong $\mathrm{H}_{2} \mathrm{~S}$ odor, some root hairs, wet

Strong $\mathrm{H}_{2} \mathrm{~S}$ odor

Strong $\mathrm{H}_{2} \mathrm{~S}$ odor, slightly drier

Very dry, root hairs and stems, abrupt contact at $\mathbf{1 5 . 5}$ in.

Drier, compacted, coarser vegetative material

Standley Lake (Site ID: SED08292)

September 9, 1992

0-0.50 Olive brown

Sand

Silty sand

Silty sand

Silty sand

Dark olive gray

$1.5-2.5$

Very dark gray

4.0-5.0 Olive gray

5.0-6.0 Very dark gray

Sand

Clayey silt

Quartz grains, muscovite, pyrite, slight $\mathrm{H}_{2} \mathrm{~S}$ odor large bark and stem

$6.0-8.0$

Dark gray

Clayey silt

Mineral grains, coarse vegetation, some roots

Smaller grain minerals, root and root hairs

Abundant root hairs and stems

Mostly quartz, very coarse stem and root material

Drier, coarse roots

Dry, very fine-grained minerals, finer roots and root hairs

Standley Lake (Site ID: SED08492)

September 9, 1992

$\begin{array}{ll}0-1.0 & \text { Olive } \\ 1.0-4.0 & \text { Olive gray } \\ 4.0-5.0 & \text { Very dark gray } \\ 5.0-6.0 & \text { Dark gray } \\ 6.0-9.0 & \text { Olive gray }\end{array}$

Silty sand

Sandy silt

Very wet, very fine-grained organics

Sand

Silty sand

Coarse quartz grains, very fine-grained organics

Coarse organics fragments, detrital stems, some roots, slight $\mathrm{H}_{2} \mathrm{~S}$ odor

Coarse pebbles, roots and stems, moist

Clayey sand

Abundant root hairs and roots, quartz grains 
Table B1. Lake-bottom-sediment core descriptions--Continued

\begin{tabular}{|c|c|c|c|}
\hline $\begin{array}{c}\text { Depth from } \\
\text { top } \\
\text { (in.) }\end{array}$ & Color & Texture & Other features/observations \\
\hline \multicolumn{4}{|c|}{$\begin{array}{c}\text { Great Western Reservoir (Site ID: SED08592 } \\
\text { August 31, } 1992\end{array}$} \\
\hline $0-0.25$ & Dark yellowish & Sandy silt & Very wet \\
\hline $0.25-4.0$ & Very dark gray & Silty clay & Wet, minor roots \\
\hline $4.0-8.0$ & Black & Clay & Lots of fine root hairs \\
\hline $11.0-13.5$ & Grayish brown & Clay & Very wet \\
\hline $13.5-14.5$ & Black & Sandy clay & Some organic materials \\
\hline $14.5-15.5$ & Very dark grayish brown & Clay & Lots of fibers and some iron oxide \\
\hline \multicolumn{4}{|c|}{$\begin{array}{c}\text { Great Western Reservoir (Site ID: SED08792 } \\
\text { September 1, } 1992\end{array}$} \\
\hline 4.5-5.5 & Very dark gray & Silty clay & Black crumbs (carbonaceous) \\
\hline $5.5-10$ & Very dark gray & Clay & $\begin{array}{l}\text { Lots of roots, root hairs, stems, } \\
\quad \text { (possibly original land surface) }\end{array}$ \\
\hline \multicolumn{4}{|c|}{$\begin{array}{l}\text { Great Western Reservoir (Site ID: SED08692) } \\
\text { September 1, } 1992\end{array}$} \\
\hline $0-0.50$ & Light olive brown & Silt & Oxidized, small worms present, very wet \\
\hline $0.50-2.0$ & Very dark gray & Silt/clayey & $\mathrm{H}_{2} \mathrm{~S}$ odor, black area, organics \\
\hline $2.0-8.0$ & Dark olive gray & Clayey silt & Fine-grained organic material, moderately wet \\
\hline $8.0-10.5$ & Olive gray with black streaks & Clayey silt & Strong $\mathrm{H}_{2} \mathrm{~S}$ odor, moderately wet \\
\hline $10.5-12.5$ & Olive & Clayey silt & Slight $\mathrm{H}_{2} \mathrm{~S}$ Odor \\
\hline $12.5-17.0$ & Dark olive gray & Silt with some & Moderately wet \\
\hline \multicolumn{4}{|c|}{$\begin{array}{c}\text { Great Western Reservoir (SIte ID: SED09192) } \\
\text { September 2, } 1992\end{array}$} \\
\hline $0-1.0$ & Light olive brown & Silty & Oxidized, some organics, very wet \\
\hline $1.0-4.5$ & Olive gray (some black) & Clayey silt & Fine-grained organics, very wet \\
\hline 4.5-6.5 & Dark olive gray & Clayey silt & Strong $\mathrm{H}_{2} \mathrm{~s}$ odor, some black streaks, wet \\
\hline $6.5-9.0$ & Olive gray & Clayey silt & Less wet, less streaky \\
\hline $9.0-9.75$ & Black & Clayey silt & Some root hairs, stronger $\mathrm{H}_{2} \mathrm{~S}$ odor \\
\hline $9.75-11.0$ & Olive gray & Silty clay & Fine-grained organic particles, wet \\
\hline $11.0-18.5$ & Olive gray & Silty clay & Few root hairs, wet \\
\hline $18.5-21.0$ & Dark olive gray & Silty clay & Drier, few root hairs \\
\hline $21.0-24.0$ & Black & Silty clay & Stem fragment, root hairs, drier still \\
\hline $24.0-31.25$ & Black & Clay & Pods of organic material, drier \\
\hline $31.25-31.5$ & Black & Clay & Mineralization \\
\hline
\end{tabular}


Table B1. Lake-bottom-sediment core descriptions--Continued

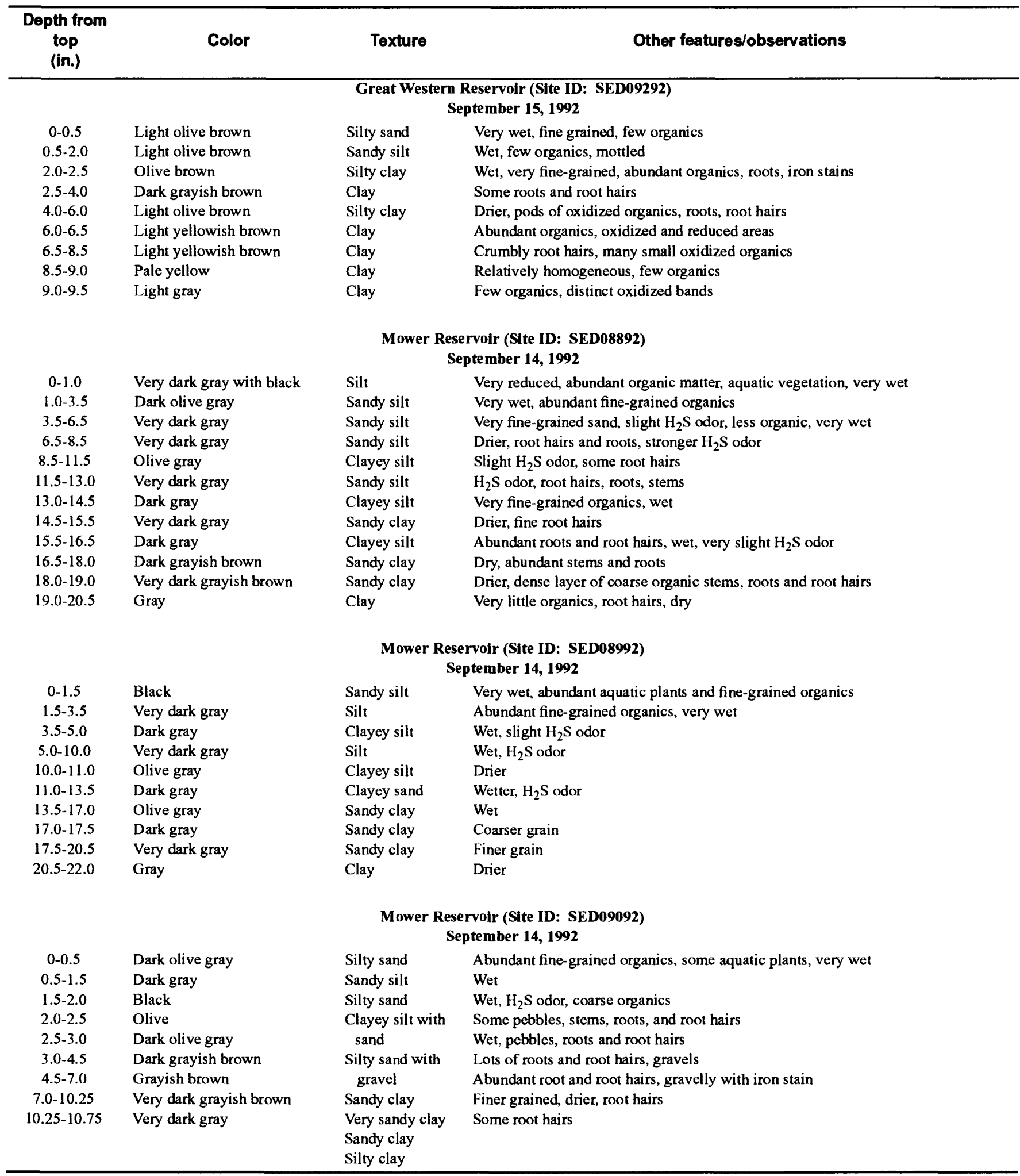




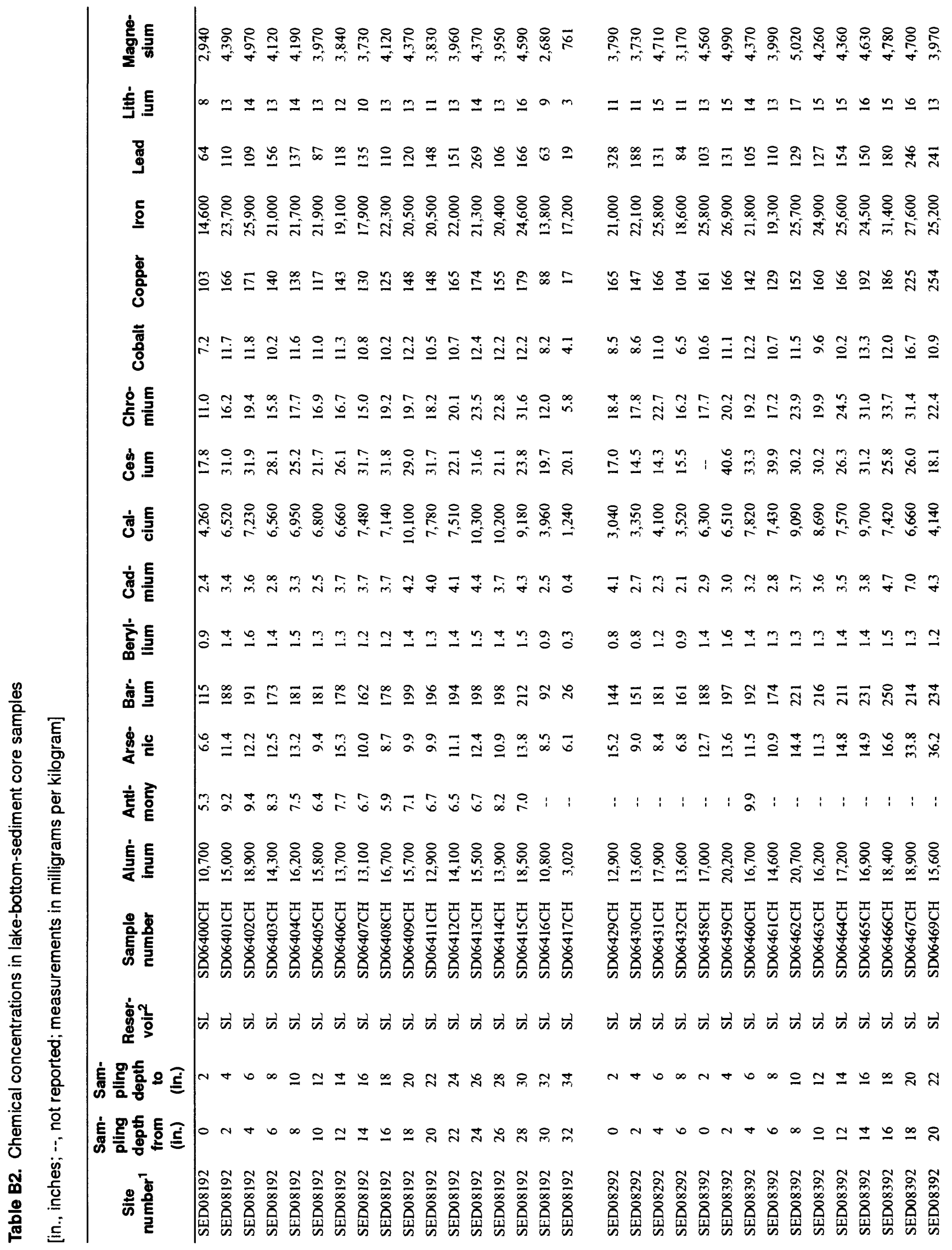




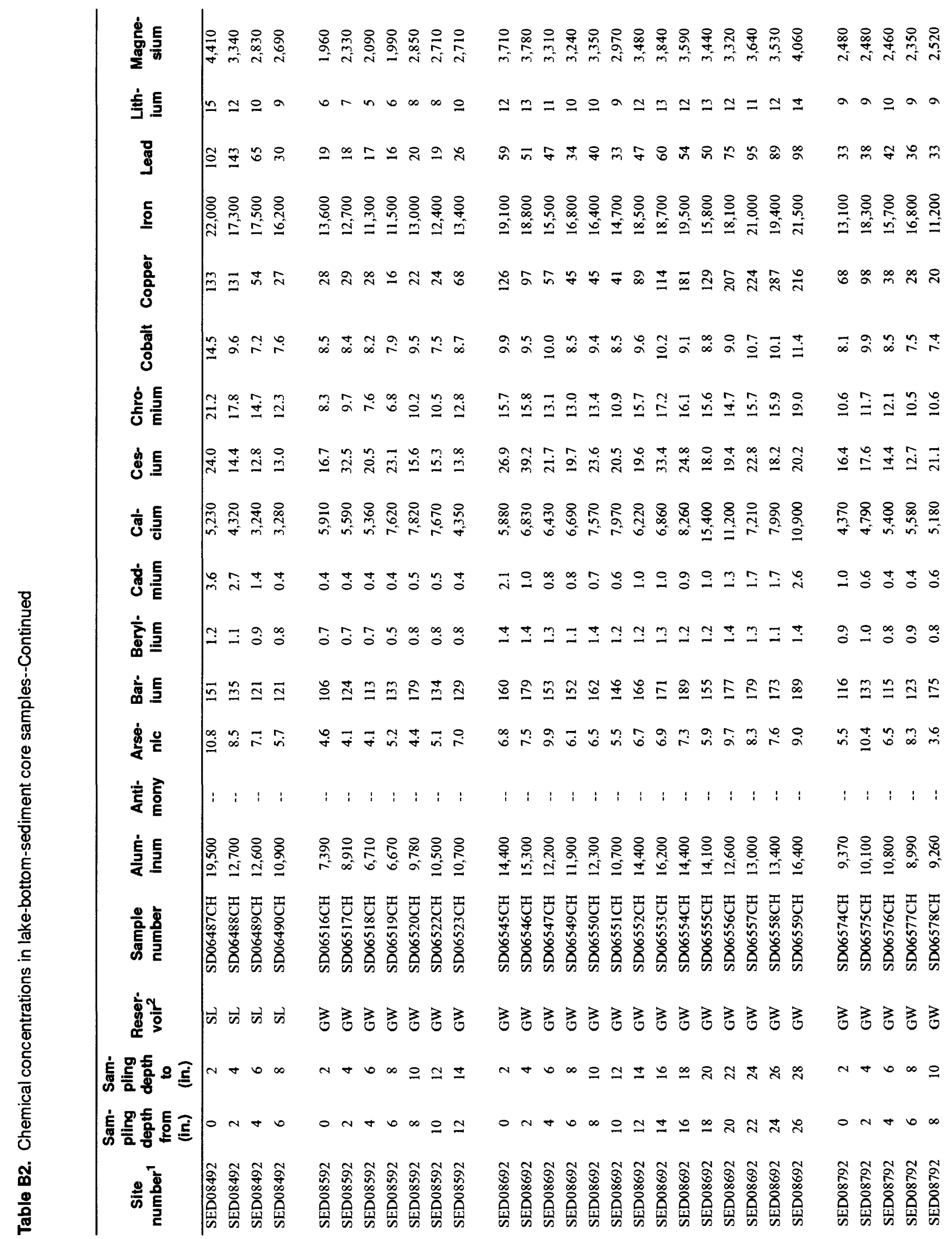

48 Characterization of Selected Radionuclides in Sediment and Surface Water in Standley Lake, Great Western Reservoir, and Mower Reservoir, Jefferson County, Colorado 1992 


\begin{tabular}{|c|c|c|c|}
\hline 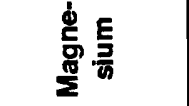 & 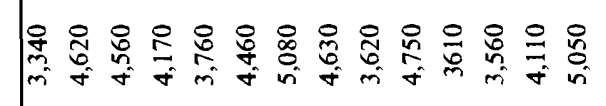 & 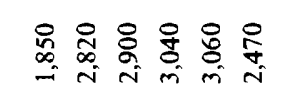 & 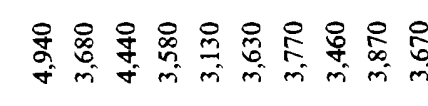 \\
\hline 㪯豆 & 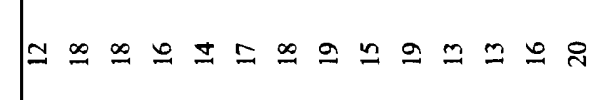 & $0=a a_{\infty} r$ & $\pm=\simeq=a \simeq \simeq=m \simeq$ \\
\hline$\stackrel{\square}{g}$ & 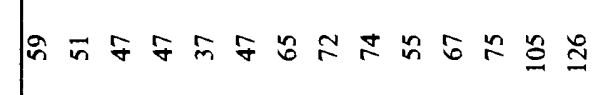 & $\check{\simeq} \mathscr{\infty}=\underline{\infty}$ & 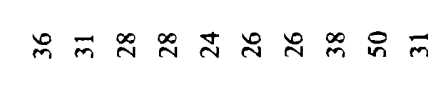 \\
\hline$\underline{\underline{\underline{s}}}$ & 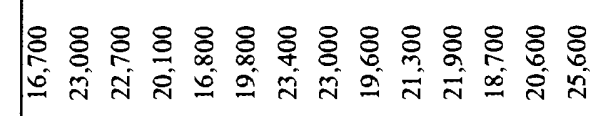 & 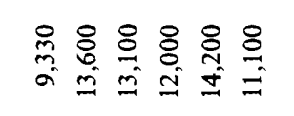 & 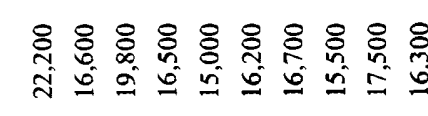 \\
\hline$\frac{5}{\frac{\mathbf{g}}{2}}$ & 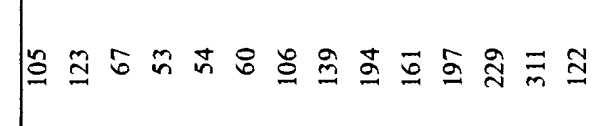 & $\therefore \approx \simeq 99$ & $\infty \approx \approx \approx \pi \approx \pi \pm \mathscr{A} \approx$ \\
\hline 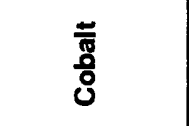 & 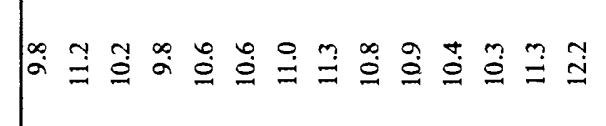 & 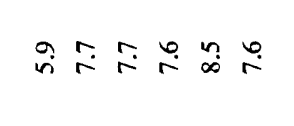 & 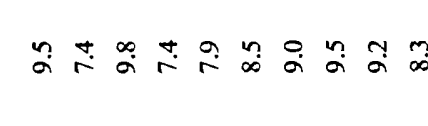 \\
\hline 它豆 & 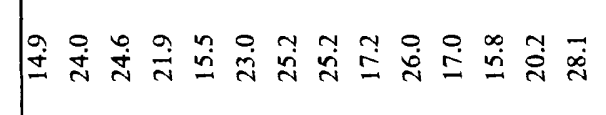 & 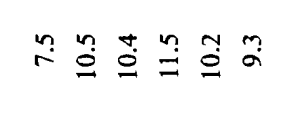 & 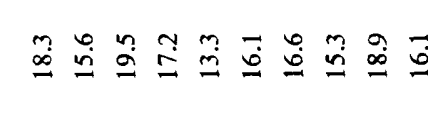 \\
\hline d. & 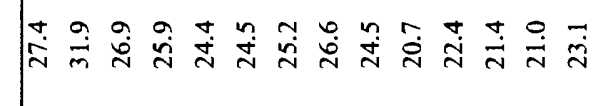 & 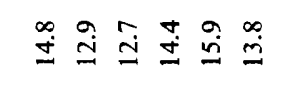 & 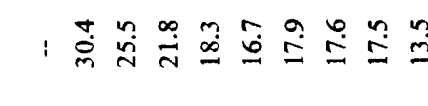 \\
\hline$\dot{\bar{s}}$ & 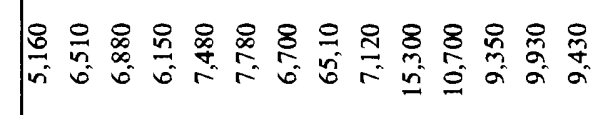 & 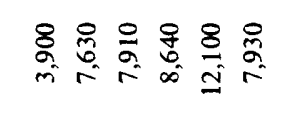 & 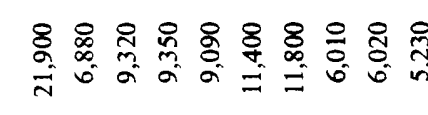 \\
\hline 它焉 & $\mid$ & 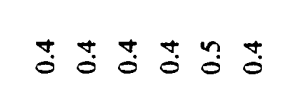 & 1 \\
\hline 商是 & 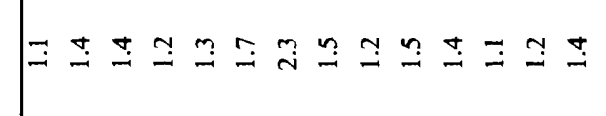 & $\stackrel{\infty}{\infty} \stackrel{\infty}{\infty} \stackrel{\infty}{0} \stackrel{8}{8} \subseteq \infty$ & $\Xi \Xi \pm \cong \Xi \Xi \Xi ェ \cong$ \\
\hline 离息 & 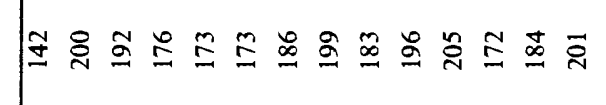 & 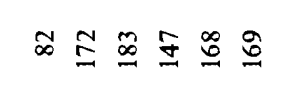 & 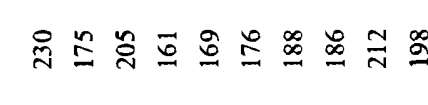 \\
\hline$\frac{\dot{\phi}}{2} \cdot \frac{0}{E}$ & 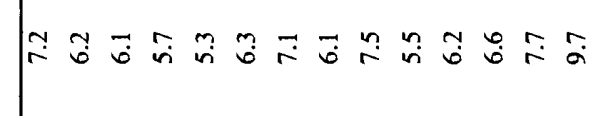 & 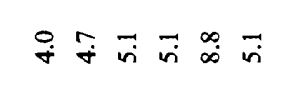 & 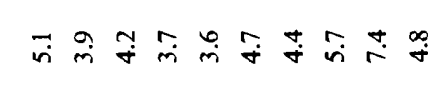 \\
\hline 妾言 & $:::::::::::::::$ & $::::::$ & $:: \quad: \quad: \quad: \quad: \quad: \quad: \quad: \quad$ \\
\hline 妾昰 & 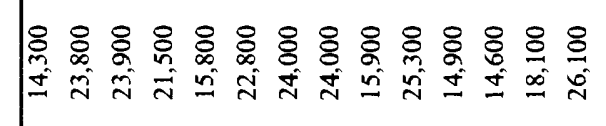 & 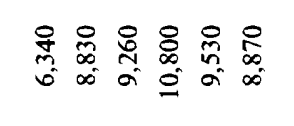 & 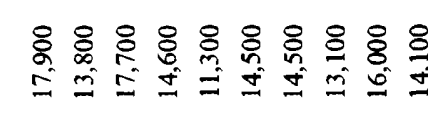 \\
\hline 递高 & 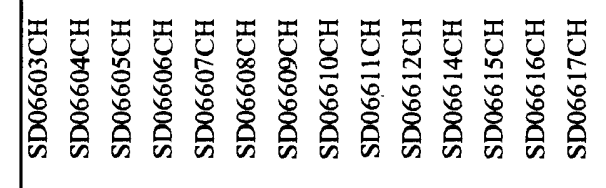 & 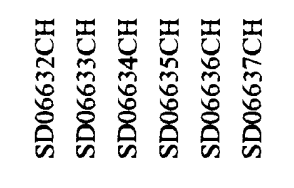 & 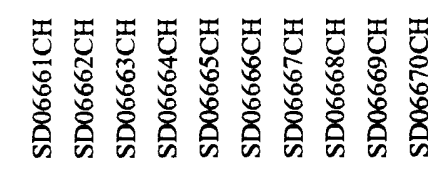 \\
\hline 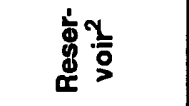 & 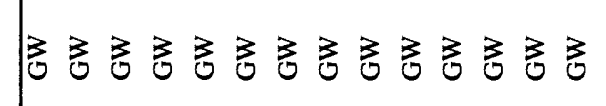 & 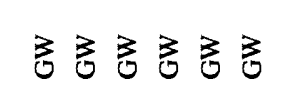 & $\Sigma \Sigma \Sigma \Sigma \Sigma \Sigma \Sigma \Sigma \Sigma \Sigma \Sigma$ \\
\hline 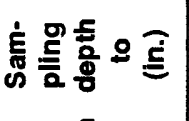 & 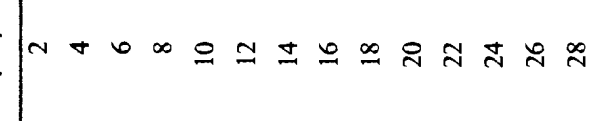 & $\sim+\infty \Omega \simeq$ & $\sim+\infty \infty \simeq \simeq \pm \simeq \simeq$ \\
\hline 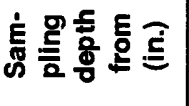 & $0 \sim+\infty= \pm \pm \underline{\infty} \approx \pi \pi d$ & $0 n+\infty=$ & $0 \sim+\infty \infty \varrho \simeq \pm \cong \mathscr{\infty}$ \\
\hline 紊毫 & 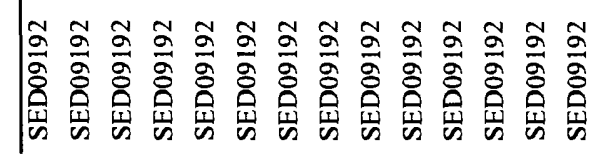 & 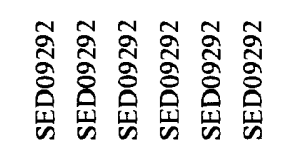 & 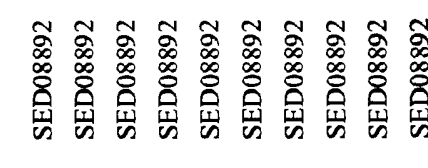 \\
\hline
\end{tabular}




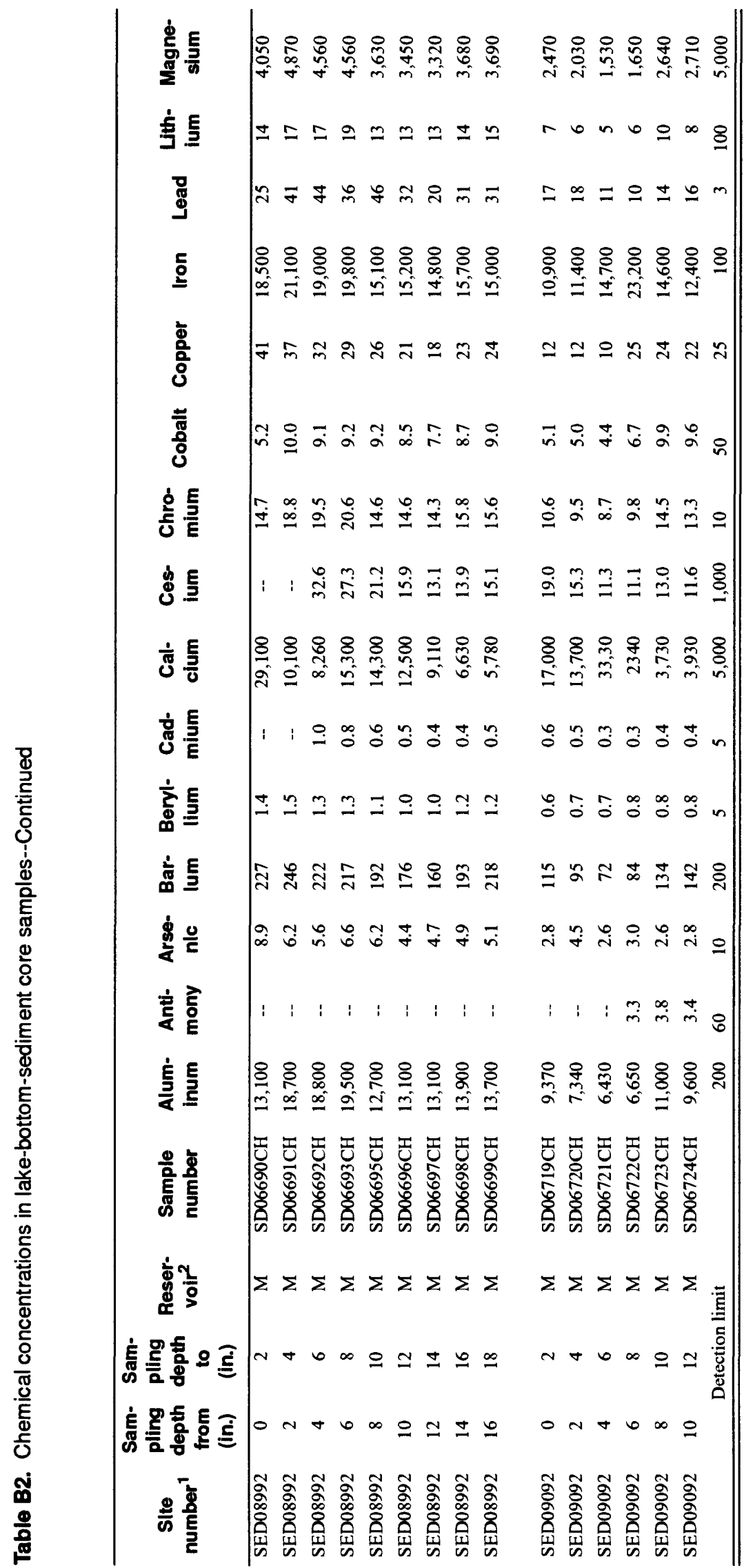

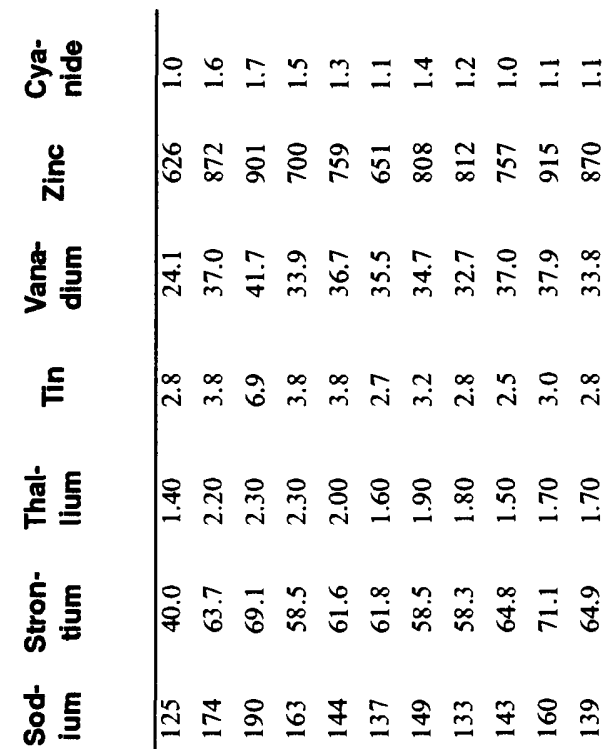
市 $\quad$ ๖

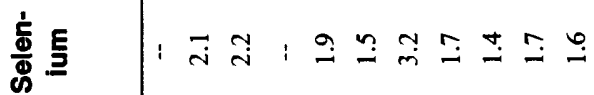

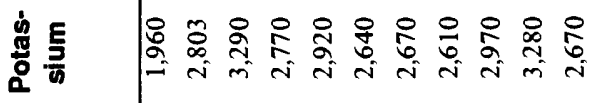

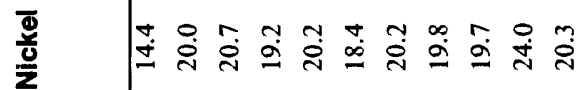
㝘焉 ๗

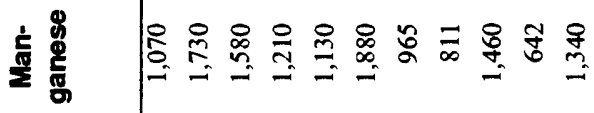

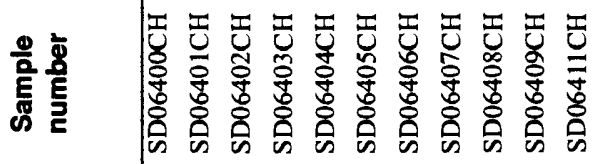
क्षे 芣容喜

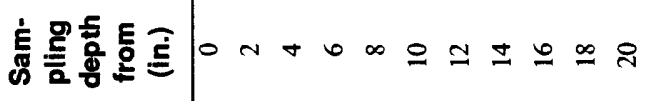

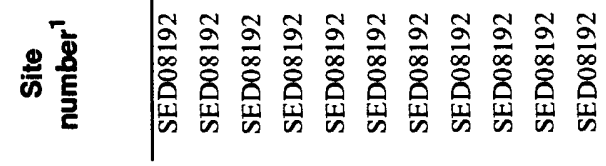




\begin{tabular}{|c|c|c|c|c|c|}
\hline 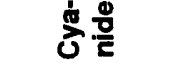 & $\Xi \Xi \Xi \Xi a ̊: 0$ & 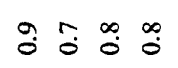 & 1: : & $\stackrel{\infty}{\prime} \stackrel{0}{0} \tilde{0}$ & 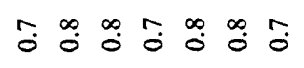 \\
\hline 气 & 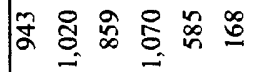 & 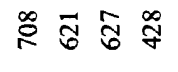 & 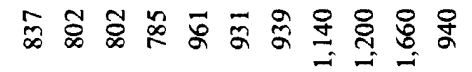 & \& 声 $\bar{F}$ & 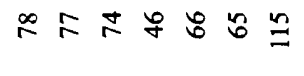 \\
\hline$\frac{\operatorname{de}}{5}$ & 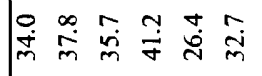 & 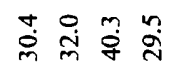 & 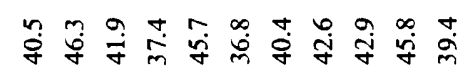 & 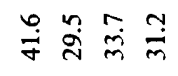 & 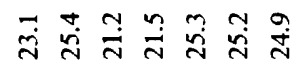 \\
\hline r & 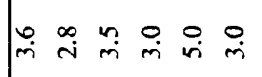 & $\vec{m} \stackrel{n}{\dot{m}} \vec{m}$ & 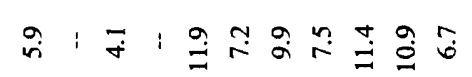 & $\mid \underset{m}{\infty} \stackrel{i}{i}:$ & $\beth \stackrel{\infty}{-} \stackrel{\infty}{-} \stackrel{\infty}{-} 9$ \\
\hline 要皇 & $\mid \begin{array}{ll}0 \\
0\end{array}$ & 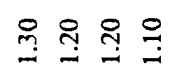 & : & 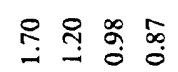 & $\stackrel{8}{8} \stackrel{9}{9} 8 \stackrel{9}{9} 9$ \\
\hline & 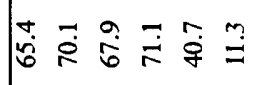 & 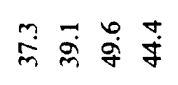 & 家 $\quad$ : & 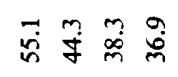 & 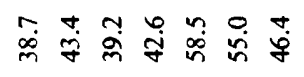 \\
\hline & 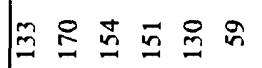 & 这㐫 & 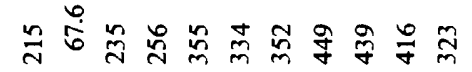 & 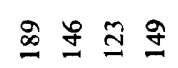 & 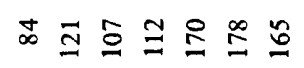 \\
\hline & $\vec{i} \stackrel{i}{i} \stackrel{a}{\vec{i}} \stackrel{9}{-} \tilde{i}$ & 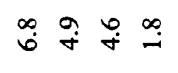 & ! & $\stackrel{\infty}{i} \stackrel{\infty}{m} \stackrel{\infty}{\sim}$ & $\stackrel{i}{i} \stackrel{\infty}{i} \tilde{i} \underset{i}{M} \stackrel{0}{m}$ \\
\hline & $\because \underset{1}{\because} \cong 2$ & $M \cong \cong \Xi$ & 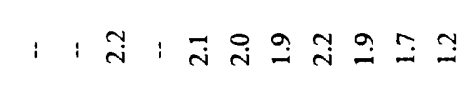 & $\cong \cong \stackrel{9}{=}$ & 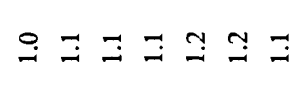 \\
\hline & 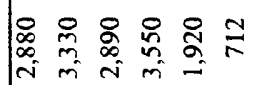 & 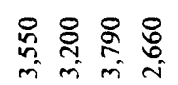 & 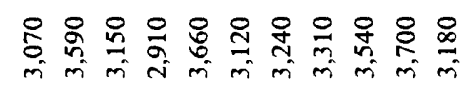 & 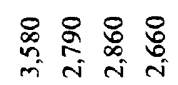 & 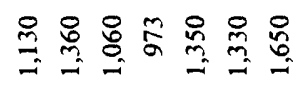 \\
\hline & 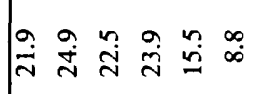 & 芯苍泀 & 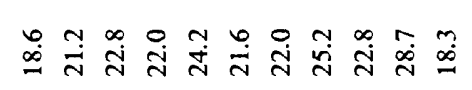 & 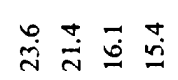 & 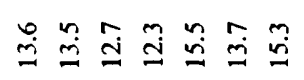 \\
\hline & 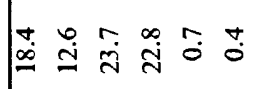 & ํํㅇำ & 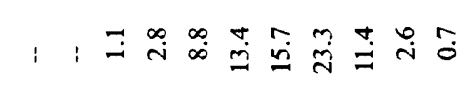 & $\stackrel{\infty}{\circ} \stackrel{\infty}{=} \stackrel{+}{0} \dot{0}$ & 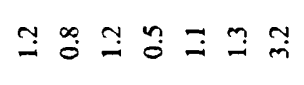 \\
\hline & 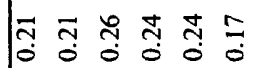 & 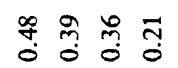 & 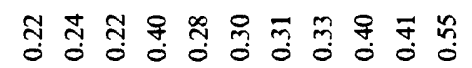 & 총 총 응 웅 & 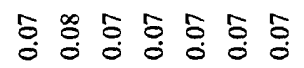 \\
\hline & 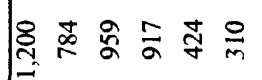 & 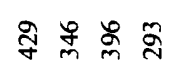 & 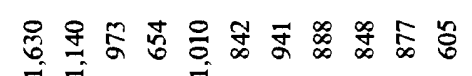 & స్ర $\tilde{m} \tilde{m}$ & 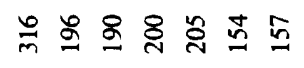 \\
\hline 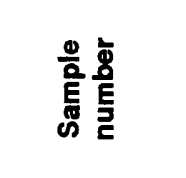 & 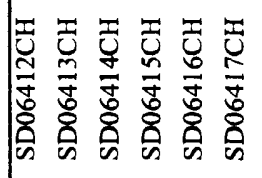 & 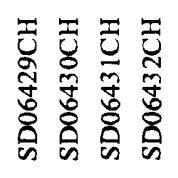 & 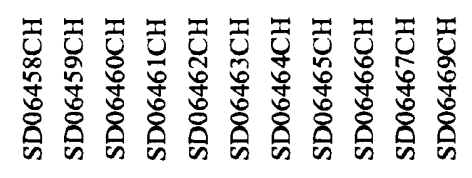 & 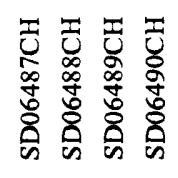 & 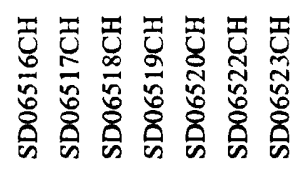 \\
\hline 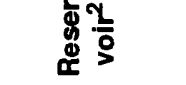 & 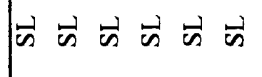 & $\vec{\omega} \vec{\omega} \vec{\omega}$ & 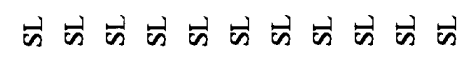 & के & 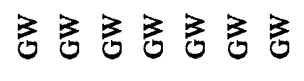 \\
\hline 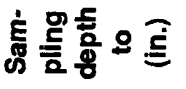 & 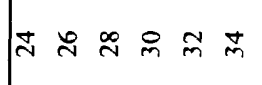 & 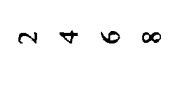 & $\sim+\infty \infty \subseteq \simeq \pm \cong$ & $N+\infty$ & $a+$ \\
\hline 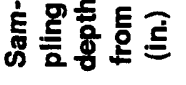 & 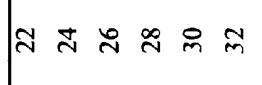 & $0 n+0$ & $0 N+\infty \infty \subseteq I \pm \cong \cong 8$ & $O n+0$ & $0 n+\infty \infty 0=$ \\
\hline 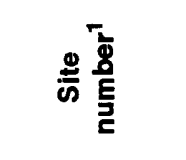 & 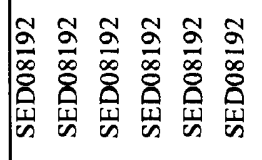 & 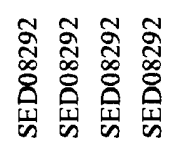 & 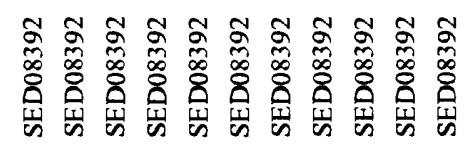 & 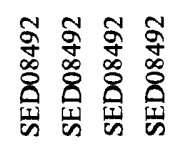 & 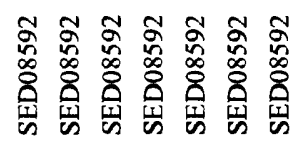 \\
\hline
\end{tabular}




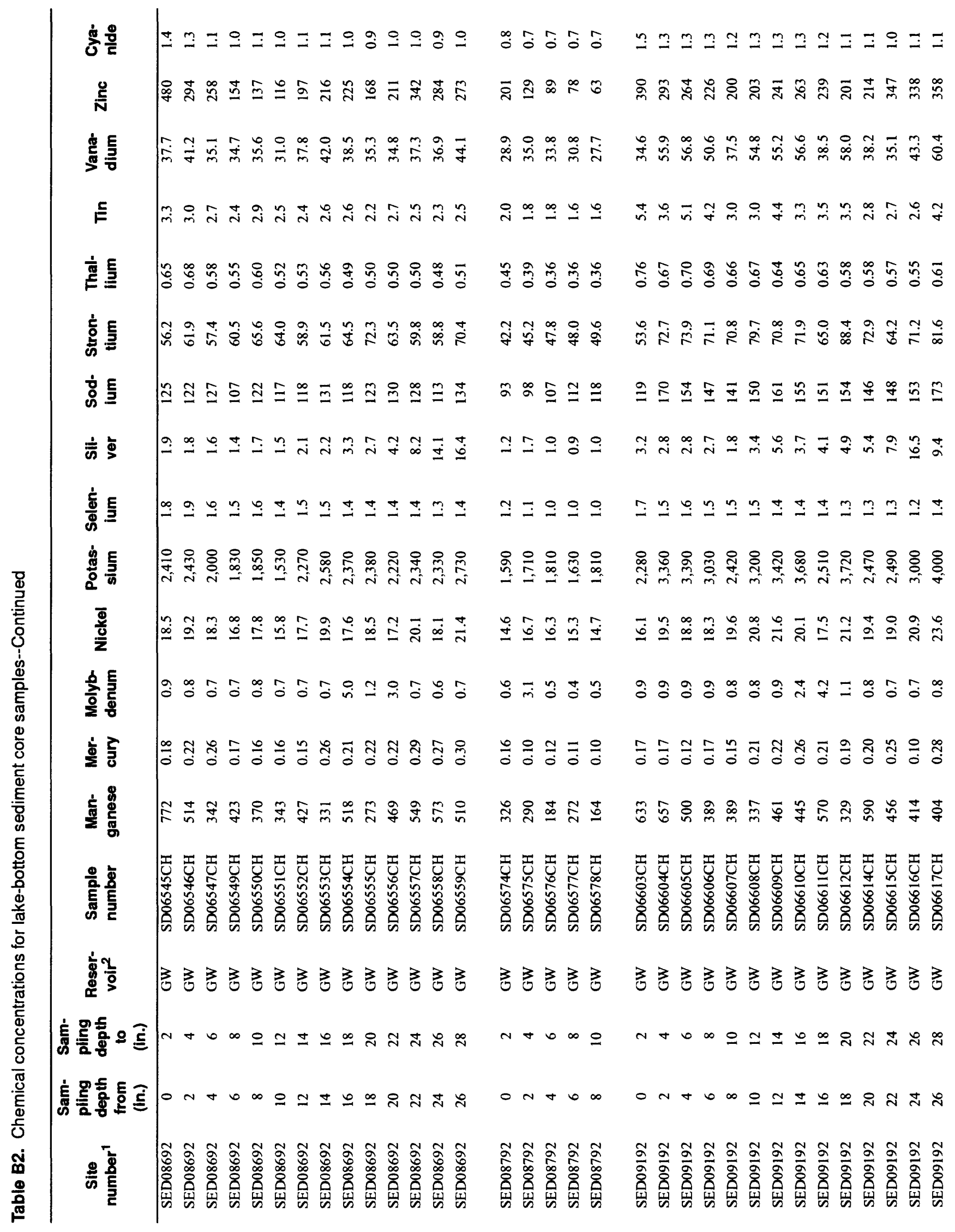




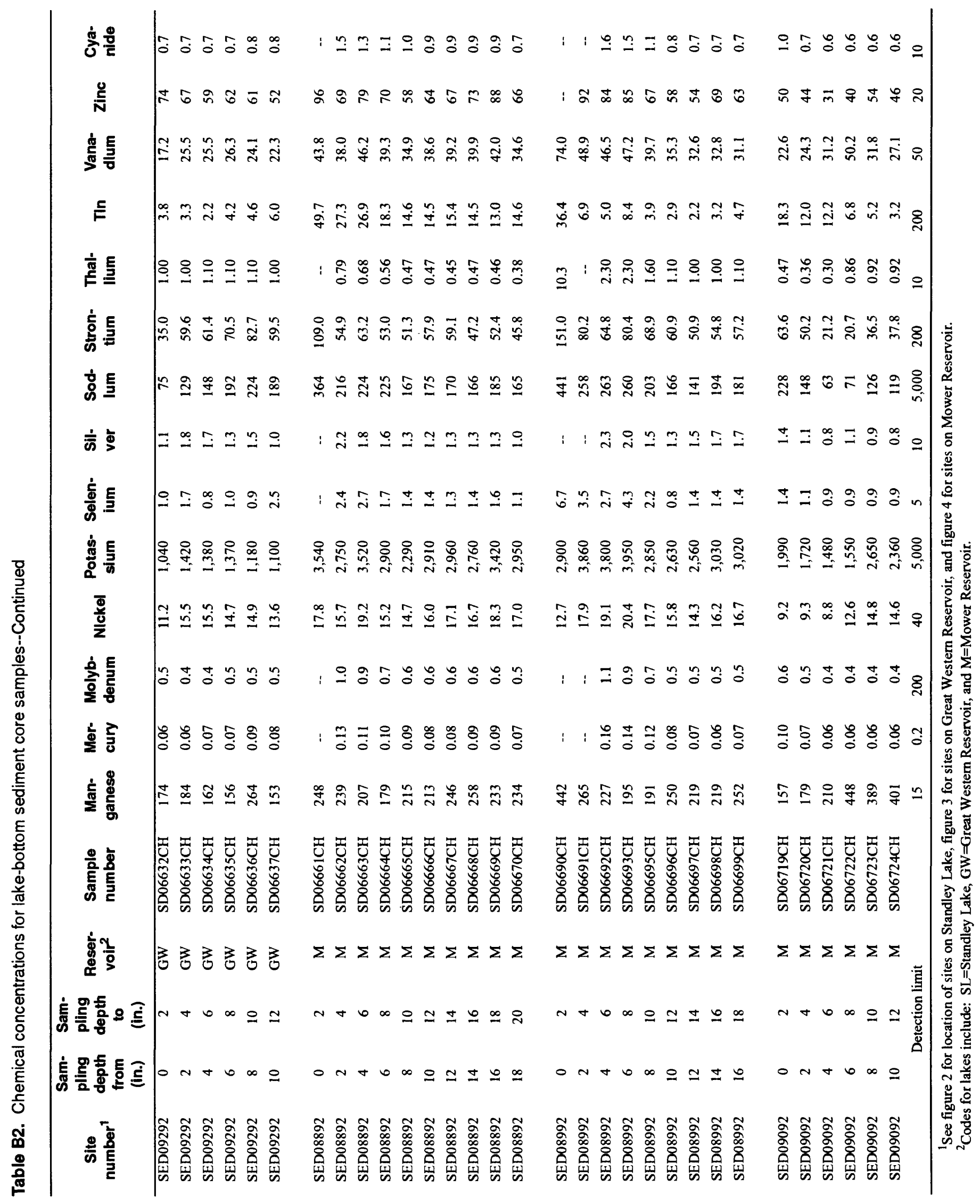




\section{APPENDIX C}

\section{Lake-water samples}


Table C1. Field measurements at lake-water-sampling sites

[ft, feet; ${ }^{\circ} \mathrm{C}$, degrees Celsius; $\mathrm{mg} / \mathrm{L}$, milligrams per liter; $\mu \mathrm{S} / \mathrm{cm}$, microsiemens per centimeter at 25 degrees Celsius]

\begin{tabular}{|c|c|c|c|c|c|c|c|c|}
\hline $\begin{array}{c}\text { Site } \\
\text { number }\end{array}$ & Reservoir ${ }^{2}$ & $\begin{array}{l}\text { Sample } \\
\text { date }\end{array}$ & $\begin{array}{c}\text { Sample } \\
\text { time }\end{array}$ & $\begin{array}{l}\text { Depth } \\
\text { (ft) }\end{array}$ & $\begin{array}{c}\text { Temperature } \\
\left({ }^{\circ} \mathrm{C}\right)\end{array}$ & $\begin{array}{l}\text { Dissolved } \\
\text { oxygen } \\
\text { (mg/L) }\end{array}$ & pH & $\begin{array}{c}\text { Specific } \\
\text { conductance } \\
(\mu \mathrm{S} / \mathrm{cm})\end{array}$ \\
\hline \multirow[t]{18}{*}{ SW00992 } & $\overline{S L}$ & $09 / 08 / 92$ & $9: 02$ & 1 & 18.1 & 8.2 & $\overline{8.2}$ & 224 \\
\hline & & & 9:02 & 5 & 18.1 & 8.1 & 8.1 & 224 \\
\hline & & & 9:03 & 10 & 18.1 & 8.0 & 8.1 & 224 \\
\hline & & & 9:04 & 15 & 18.1 & 7.9 & 8.1 & 224 \\
\hline & & & 9:05 & 20 & 18.1 & 7.9 & 8.1 & 223 \\
\hline & & & 9:06 & 25 & 18.1 & 7.9 & 8.1 & 224 \\
\hline & & & 9:07 & 30 & 18.1 & 7.8 & 8.1 & 224 \\
\hline & & & 9:08 & 35 & 18.1 & 7.8 & 8.1 & 224 \\
\hline & & & 9:09 & 40 & 18.0 & 7.7 & 8.1 & 223 \\
\hline & & & $9: 10$ & 45 & 18.0 & 7.3 & 8.0 & 223 \\
\hline & & & $9: 11$ & 50 & 17.9 & 6.5 & 8.0 & 223 \\
\hline & & & 9:11 & 55 & 17.0 & 5.6 & 7.9 & 224 \\
\hline & & & $9: 12$ & 60 & 17.3 & 3.1 & 7.9 & 228 \\
\hline & & & $9: 13$ & 65 & 17.1 & 2.4 & 7.8 & 228 \\
\hline & & & $9: 14$ & 70 & 17.0 & 1.9 & 7.7 & 229 \\
\hline & & & $9: 15$ & 72.5 & 16.4 & 0.4 & 7.6 & 234 \\
\hline & & & $9: 16$ & 75 & 15.1 & 0.3 & 7.5 & 246 \\
\hline & & & $9: 17$ & 80 & 14.8 & 0.3 & 7.5 & 249 \\
\hline \multirow[t]{6}{*}{ SW01092 } & SL & $09 / 09 / 92$ & $9: 52$ & 1 & 17.7 & 7.2 & 8.0 & 226 \\
\hline & & & $9: 52$ & 5 & 17.7 & 7.2 & 8.0 & 226 \\
\hline & & & $9: 53$ & 10 & 17.7 & 7.2 & 8.0 & 226 \\
\hline & & & 9:54 & 15 & 17.6 & 7.1 & 8.0 & 226 \\
\hline & & & $9: 55$ & 20 & 17.6 & 7.1 & 8.0 & 226 \\
\hline & & & $9: 56$ & 21 & 17.5 & 7.0 & 8.0 & 226 \\
\hline \multirow[t]{14}{*}{ SW01 192} & SL & $09 / 08 / 92$ & 11:00 & 1 & 18.4 & 8.0 & 7.8 & 226 \\
\hline & & & $11: 01$ & 5 & 18.3 & 8.0 & 7.8 & 226 \\
\hline & & & 11:01 & 10 & 18.1 & 7.9 & 7.8 & 228 \\
\hline & & & 11:02 & 15 & 18.0 & 7.9 & 7.8 & 227 \\
\hline & & & 11:03 & 20 & 18.0 & 7.8 & 7.8 & 227 \\
\hline & & & 11:03 & 25 & 18.0 & 7.8 & 7.8 & 227 \\
\hline & & & 11:04 & 30 & 18.0 & 7.6 & 7.8 & 226 \\
\hline & & & 11:04 & 35 & 18.0 & 7.2 & 7.8 & 226 \\
\hline & & & 11:05 & 40 & 17.9 & 6.7 & 7.7 & 227 \\
\hline & & & 11:06 & 45 & 17.9 & 6.0 & 7.7 & 225 \\
\hline & & & $11: 07$ & 50 & 17.8 & 5.7 & 7.6 & 224 \\
\hline & & & $11: 08$ & 55 & 17.7 & 5.4 & 7.6 & 224 \\
\hline & & & 11:09 & 60 & 17.7 & 5.1 & 7.6 & 224 \\
\hline & & & $11: 09$ & 65 & 17.4 & 4.0 & 7.6 & 225 \\
\hline
\end{tabular}


Table C1. Field measurements at lake-water-sampling sites--Continued

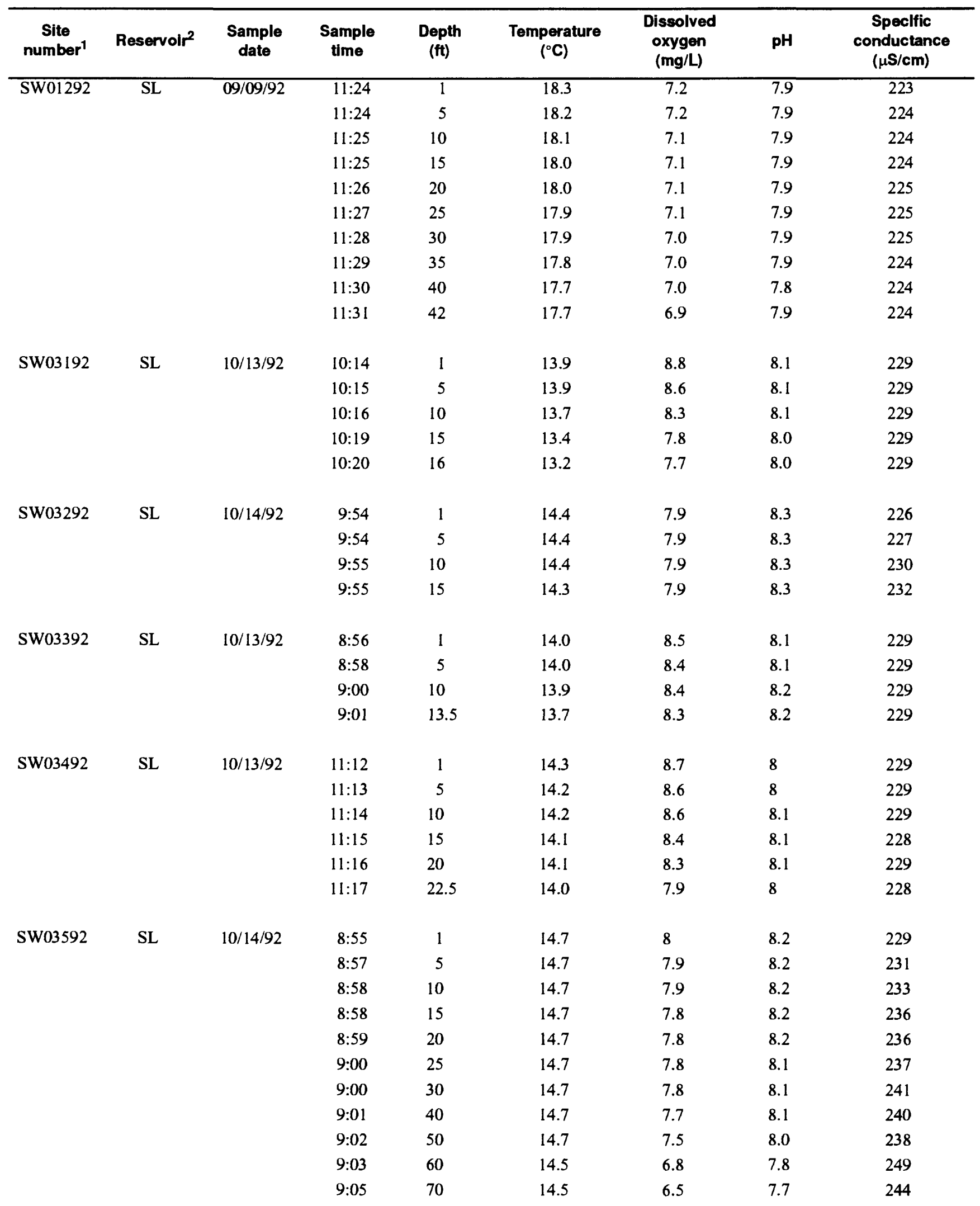


Table C1. Field measurements at lake-water-sampling sites--Continued

\begin{tabular}{|c|c|c|c|c|c|c|c|c|}
\hline $\begin{array}{c}\text { Site } \\
\text { number }\end{array}$ & Reservolr ${ }^{2}$ & $\begin{array}{c}\text { Sample } \\
\text { date }\end{array}$ & $\begin{array}{c}\text { Sample } \\
\text { time }\end{array}$ & $\begin{array}{l}\text { Depth } \\
\text { (ft) }\end{array}$ & $\begin{array}{c}\text { Temperature } \\
\left({ }^{\circ} \mathrm{C}\right)\end{array}$ & $\begin{array}{c}\text { Dissolved } \\
\text { oxygen } \\
\text { (mg/L) }\end{array}$ & pH & $\begin{array}{c}\text { Specific } \\
\text { conductance } \\
(\mu \mathrm{S} / \mathrm{cm})\end{array}$ \\
\hline \multirow[t]{4}{*}{ SW01392 } & $\overline{G W}$ & $08 / 31 / 92$ & $9: 00$ & 1 & 18.5 & 7.6 & 8.3 & 184 \\
\hline & & & 9:01 & 5 & 18.4 & 7.5 & 8.3 & 183 \\
\hline & & & 9:02 & 10 & 18.3 & 7.5 & 8.3 & 184 \\
\hline & & & 9:03 & 14.5 & 17.5 & 7.6 & 8.3 & 185 \\
\hline \multirow[t]{8}{*}{ SW01492 } & GW & $09 / 01 / 92$ & $11: 50$ & 1 & 18.3 & 7.6 & 8.3 & 182 \\
\hline & & & $11: 51$ & 5 & 18.3 & 7.6 & 8.3 & 183 \\
\hline & & & 11:52 & 10 & 18.3 & 7.5 & 8.3 & 185 \\
\hline & & & $11: 53$ & 15 & 18.3 & 7.5 & 8.3 & 189 \\
\hline & & & $11: 54$ & 20 & 18.2 & 7.5 & 8.2 & 190 \\
\hline & & & 11:55 & 25 & 18.2 & 7.4 & 8.2 & 192 \\
\hline & & & $11: 56$ & 30 & 18.2 & 7.4 & 8.2 & 195 \\
\hline & & & $11: 57$ & 35 & 18.1 & 7.1 & 8.1 & 197 \\
\hline \multirow[t]{9}{*}{ SW01692 } & GW & $09 / 02 / 92$ & $8: 35$ & 1 & 17.8 & 7.7 & 8.3 & 184 \\
\hline & & & $8: 35$ & 5 & 17.8 & 7.7 & 8.3 & 184 \\
\hline & & & $8: 36$ & 10 & 17.8 & 7.6 & 8.3 & 185 \\
\hline & & & $8: 37$ & 15 & 17.8 & 7.6 & 8.2 & 191 \\
\hline & & & $8: 38$ & 20 & 17.8 & 7.5 & 8.2 & 193 \\
\hline & & & $8: 39$ & 25 & 17.8 & 7.5 & 8.2 & 194 \\
\hline & & & $8: 40$ & 30 & 17.7 & 7.5 & 8.2 & 196 \\
\hline & & & $8: 41$ & 35 & 17.6 & 7.5 & 8.2 & 199 \\
\hline & & & $8: 42$ & 38 & 17.4 & 7.4 & 8.1 & 204 \\
\hline \multirow[t]{5}{*}{ SW01592 } & GW & $09 / 01 / 92$ & 9:16 & 1 & 18.0 & 7.6 & 8.3 & 183 \\
\hline & & & 9:17 & 5 & 18.0 & 7.6 & 8.3 & 183 \\
\hline & & & $9: 18$ & 10 & 18.0 & 7.6 & 8.3 & 183 \\
\hline & & & 9:20 & 15 & 18.0 & 7.6 & 8.3 & 185 \\
\hline & & & $9: 21$ & 18 & 17.7 & 7.4 & 8.2 & 191 \\
\hline SW01792 & GW & $09 / 15 / 92$ & $9: 17$ & 1 & 18.3 & 8.4 & 8.3 & 187 \\
\hline \multirow[t]{3}{*}{ SW02192 } & GW & $10 / 02 / 92$ & $12: 18$ & 1 & 17.0 & 8.2 & 8.3 & 181 \\
\hline & & & $12: 19$ & 5 & 16.7 & 8.2 & 8.3 & 183 \\
\hline & & & $12: 20$ & 8 & 16.4 & 8.2 & 8.3 & 187 \\
\hline \multirow[t]{5}{*}{ SW02292 } & GW & $10 / 02 / 92$ & 11:11 & 1 & 16.2 & 8.1 & 8.3 & 183 \\
\hline & & & $11: 12$ & 5 & 15.8 & 8.1 & 8.3 & 184 \\
\hline & & & 11:13 & 10 & 15.6 & 8.0 & 8.2 & 189 \\
\hline & & & 11:14 & 15 & 15.5 & 8.1 & 8.3 & 191 \\
\hline & & & 11:15 & 17 & 15.4 & 8.2 & 8.3 & 191 \\
\hline
\end{tabular}


Table C1. Field measurements at lake-water-sampling sites--Continued

\begin{tabular}{|c|c|c|c|c|c|c|c|c|}
\hline $\begin{array}{c}\text { Site } \\
\text { number }^{1}\end{array}$ & Reservoir ${ }^{2}$ & $\begin{array}{l}\text { Sample } \\
\text { date }\end{array}$ & $\begin{array}{c}\text { Sample } \\
\text { time }\end{array}$ & $\begin{array}{l}\text { Depth } \\
\text { (ft) }\end{array}$ & $\begin{array}{l}\text { Temperature } \\
\left({ }^{\circ} \mathrm{C}\right)\end{array}$ & $\begin{array}{c}\text { Dissolved } \\
\text { oxygen } \\
\text { (mg/L) }\end{array}$ & pH & $\begin{array}{c}\text { Specific } \\
\text { conductance } \\
(\mu \mathrm{S} / \mathrm{cm})\end{array}$ \\
\hline \multirow[t]{8}{*}{ SW02392 } & $\overline{\mathrm{GW}}$ & $10 / 02 / 92$ & $8: 37$ & 1 & 15.6 & 7.8 & 8.0 & 183 \\
\hline & & & $8: 39$ & 5 & 15.6 & 7.8 & 8.0 & 185 \\
\hline & & & $8: 40$ & 10 & 15.6 & 7.8 & 8.0 & 189 \\
\hline & & & $8: 40$ & 15 & 15.6 & 7.7 & 8.0 & 191 \\
\hline & & & $8: 41$ & 20 & 15.6 & 7.7 & 8.0 & 194 \\
\hline & & & $8: 42$ & 25 & 15.6 & 7.6 & 7.9 & 196 \\
\hline & & & $8: 43$ & 30 & 15.5 & 7.5 & 7.9 & 196 \\
\hline & & & $8: 45$ & 33 & 15.5 & 7.3 & 7.8 & 198 \\
\hline \multirow[t]{2}{*}{ SW02492 } & GW & $10 / 02 / 92$ & $10: 30$ & 1 & 16.1 & 7.9 & 8.2 & 179 \\
\hline & & & $10: 31$ & 2.5 & 16.1 & 7.9 & 8.2 & 181 \\
\hline \multirow[t]{7}{*}{ SW01892 } & $\mathbf{M}$ & $09 / 14 / 92$ & 10:05 & 1 & 17.3 & 7 & 10.3 & 276 \\
\hline & & & 10:09 & 3 & 16.9 & 4.8 & 10.1 & 271 \\
\hline & & & 10:10 & 5 & 16.6 & 2.0 & 9.7 & 268 \\
\hline & & & $10: 11$ & 6 & 16.4 & 0.6 & 9.6 & 270 \\
\hline & & & $10: 52$ & 1 & 17.3 & 9.7 & 10.4 & 282 \\
\hline & & & $10: 53$ & 3 & 16.9 & 8.3 & 10.2 & 276 \\
\hline & & & 10:55 & 5 & 16.3 & 2.0 & 9.8 & 269 \\
\hline SW02092 & $\mathbf{M}$ & $09 / 14 / 92$ & 13:02 & 0.5 & 22.0 & 12.5 & 9.9 & 272 \\
\hline \multirow[t]{2}{*}{ SW02692 } & $\mathbf{M}$ & $10 / 08 / 92$ & & 1 & 8.4 & 9.6 & 10.1 & 270 \\
\hline & & & & 3 & 8.1 & 8.8 & 10.1 & 271 \\
\hline \multirow[t]{2}{*}{ SW02792 } & $\mathbf{M}$ & $10 / 08 / 92$ & $12: 04$ & 1 & 9.5 & 9.6 & 10.2 & 269 \\
\hline & & & $12: 05$ & 3 & 8.7 & 9.2 & 10.2 & 268 \\
\hline \multirow[t]{2}{*}{ SW02892 } & $\mathbf{M}$ & $10 / 08 / 92$ & $11: 20$ & 1 & 9.6 & 8.2 & 10.1 & 268 \\
\hline & & & $11: 22$ & 3 & 9.4 & 7.6 & 10.1 & 269 \\
\hline SW02992 & $\mathbf{M}$ & $10 / 08 / 92$ & $8: 56$ & 1 & 7.7 & 5.9 & 10.0 & 267 \\
\hline \multirow[t]{2}{*}{ SW03092 } & $\mathbf{M}$ & $10 / 08 / 92$ & $10: 30$ & 1 & 9.3 & 7.6 & 10.1 & 268 \\
\hline & & & $10: 31$ & 4 & 9.1 & 6.6 & 10.1 & 268 \\
\hline
\end{tabular}

${ }^{1}$ See figure 2 for location of sites on Standley Lake, figure 3 for sites on Great Western Reservoir, and figure 4 for sites on Mower Reservoir.

${ }^{2}$ Codes for lakes include: $\mathrm{SL}=$ Standley Lake, $\mathrm{GW}=\mathrm{Great}$ Western Reservoir, and $\mathrm{M}=$ Mower Reservoir. 


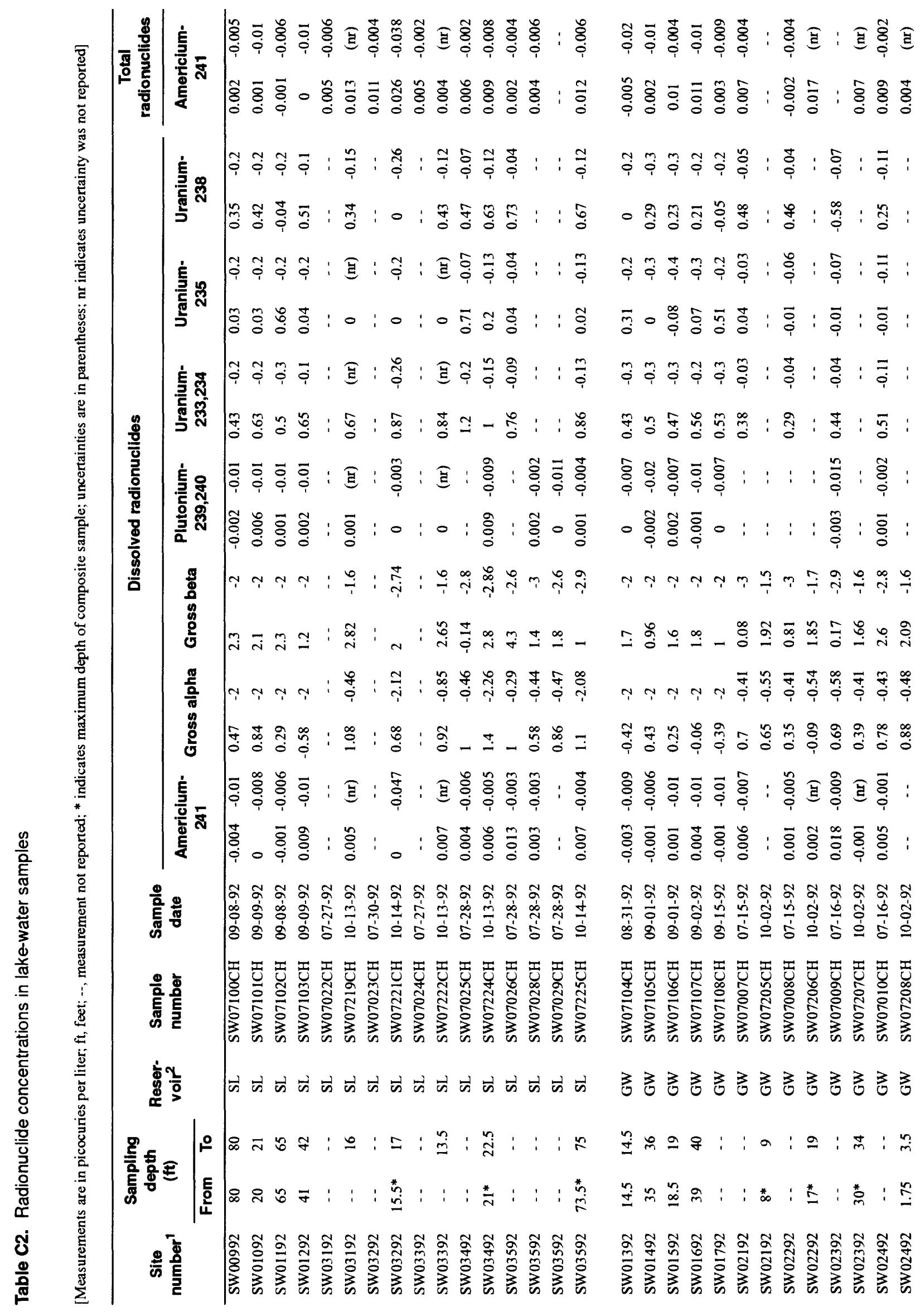



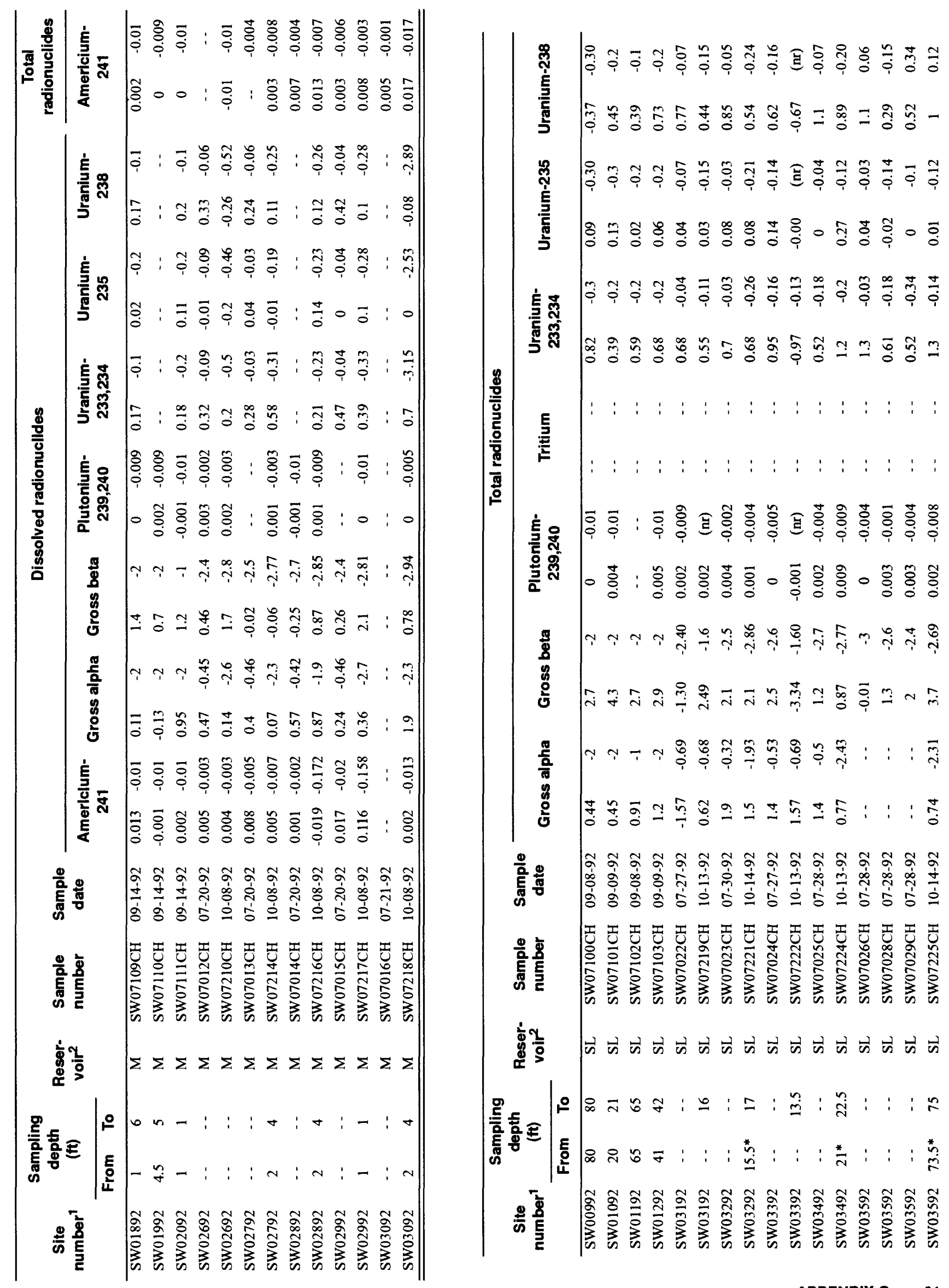


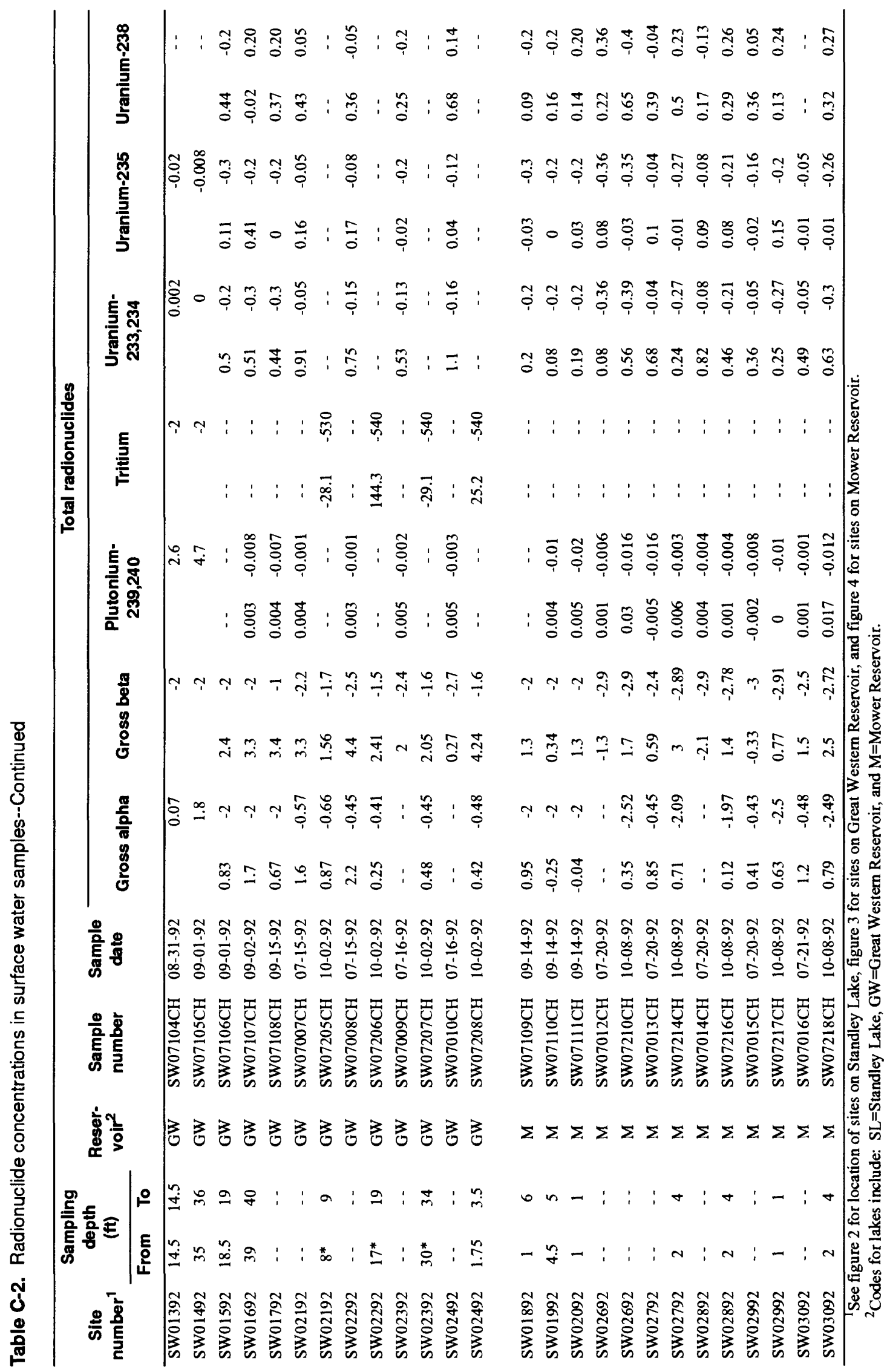

62 Characterization of Selected Radionuclides in Sediment and Surface Water in Standley Lake, Great Western Reservoir, and Mower Reservoir, Jefferson County, Colorado, 1992 


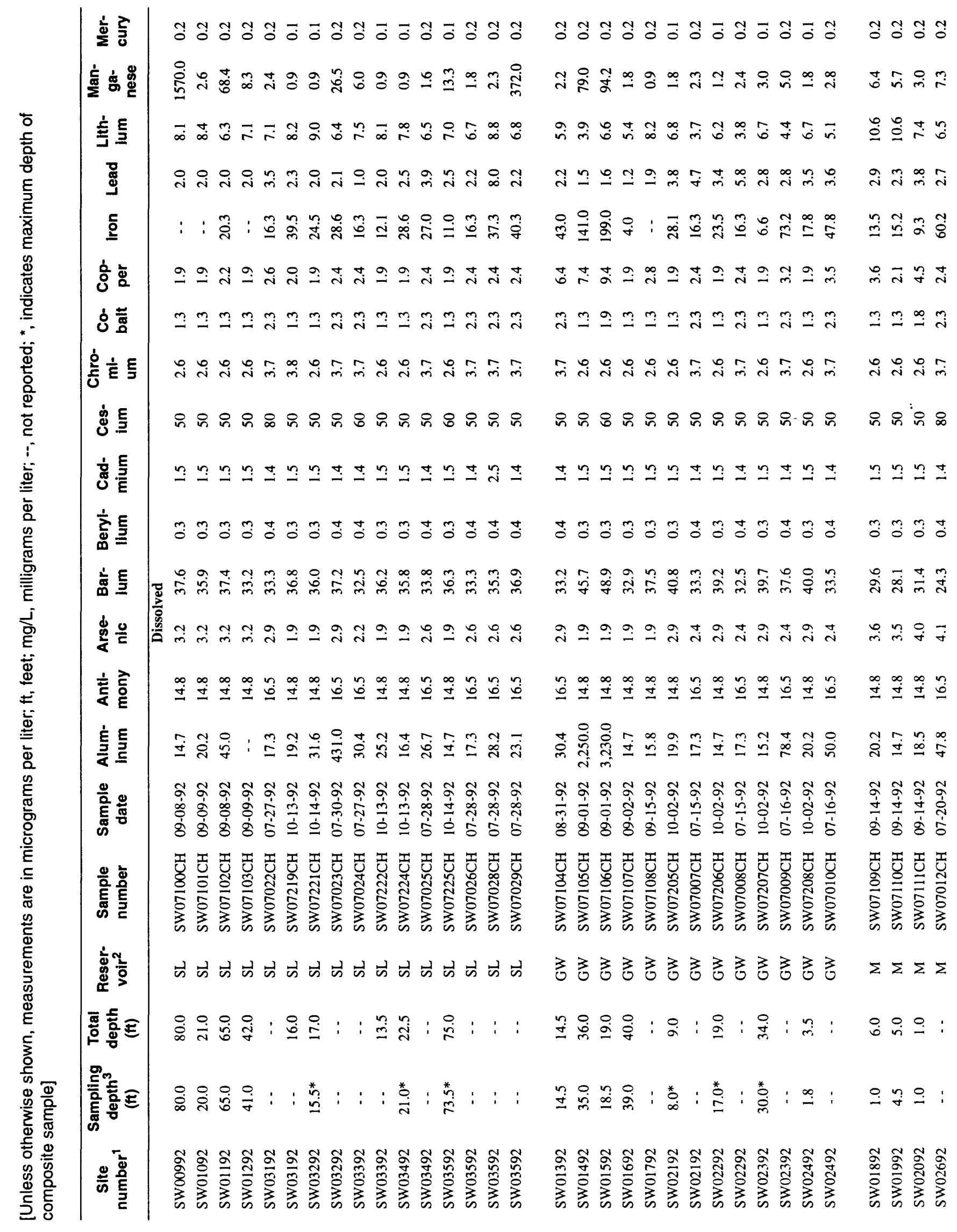




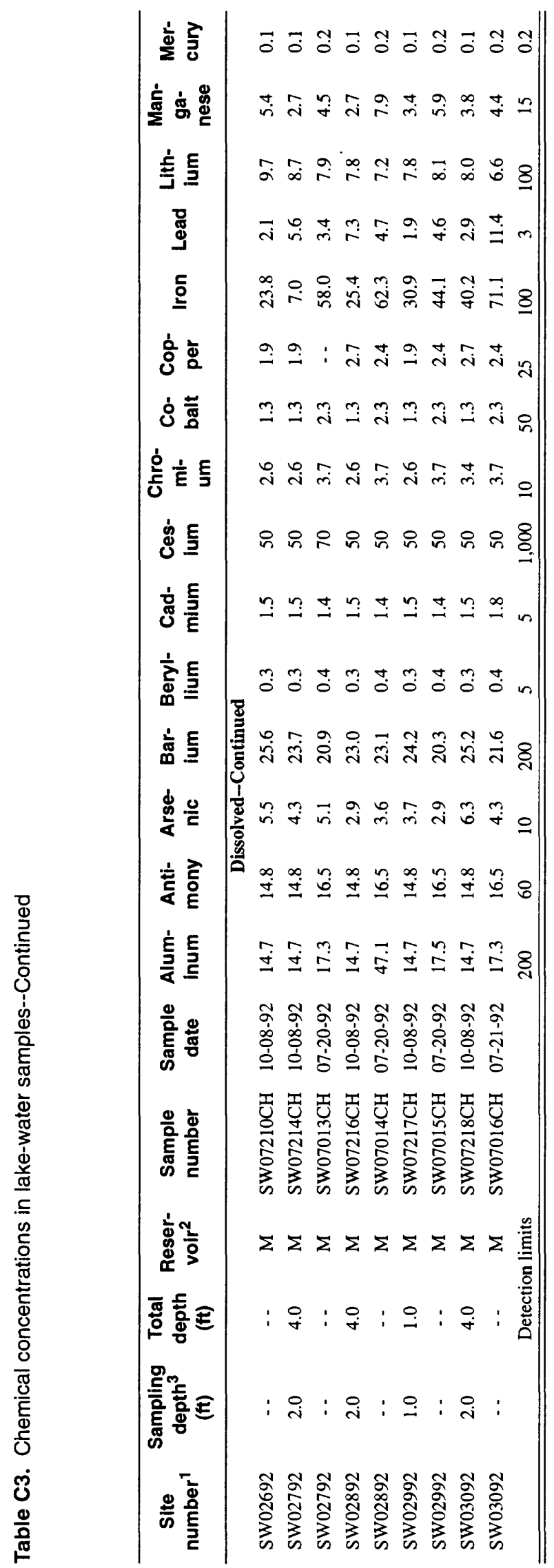

\begin{tabular}{|c|c|}
\hline \&் & 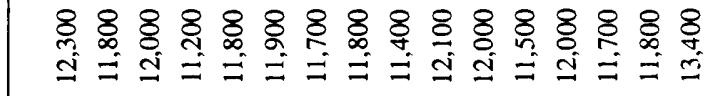 \\
\hline 言 。 & 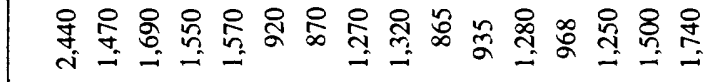 \\
\hline 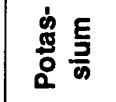 & 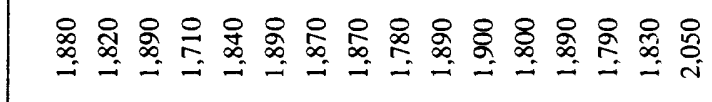 \\
\hline 迹 它 & 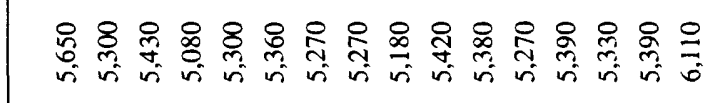 \\
\hline ठळ & 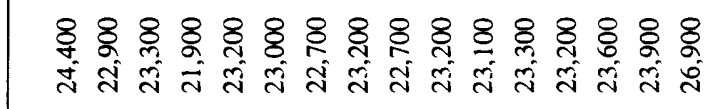 \\
\hline$\stackrel{\mathscr{L}}{\mathrm{N}}$ & 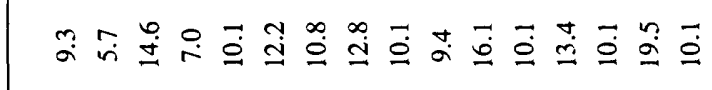 \\
\hline 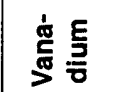 & 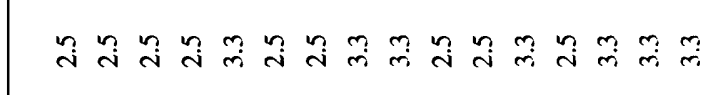 \\
\hline$\widehat{E}$ & $:$ : \\
\hline 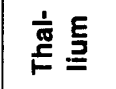 & 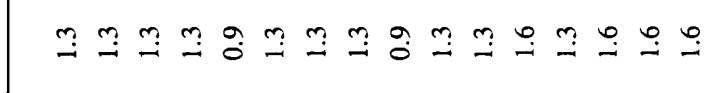 \\
\hline 总 & 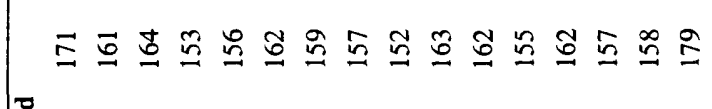 \\
\hline$\frac{1}{\bar{े}}$ & : $: \quad: \quad$ i \\
\hline 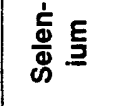 & 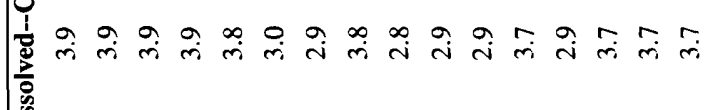 \\
\hline$\frac{0}{2}$ & 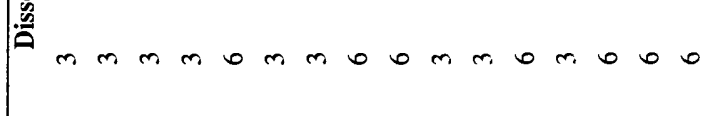 \\
\hline ì & 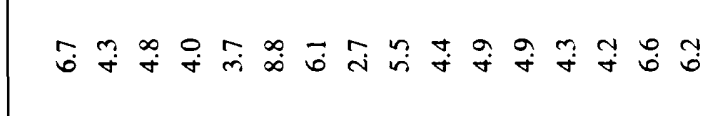 \\
\hline \% & 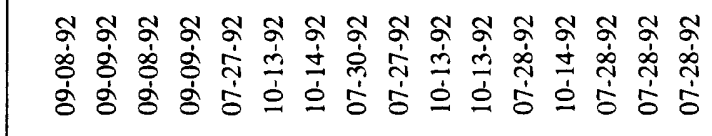 \\
\hline 哭市 & 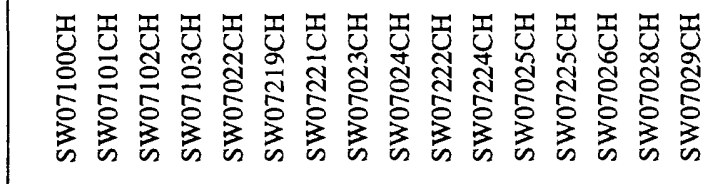 \\
\hline 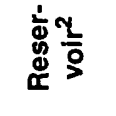 & 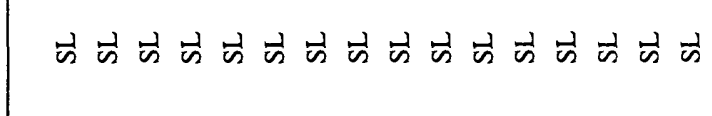 \\
\hline פ吉 & 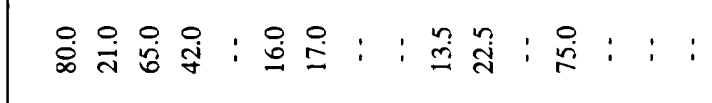 \\
\hline 言产 & 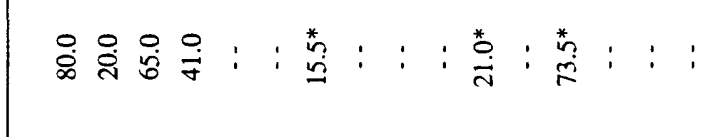 \\
\hline 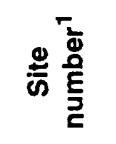 & 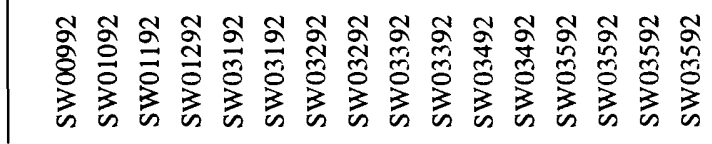 \\
\hline
\end{tabular}

64 Characterization of Selected Radionuclides in Sediment and Surface Water in Standley Lake, Great Western Reservoir, and Mower Reservoir, Jefferson County, Colorado, 1992 


\begin{tabular}{|c|c|c|}
\hline 离点 & 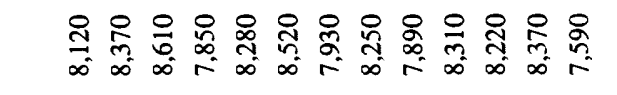 & 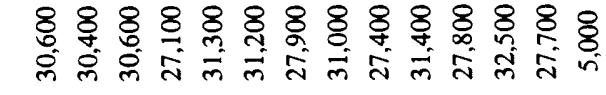 \\
\hline$\overline{\bar{c} \bar{~}}$ & 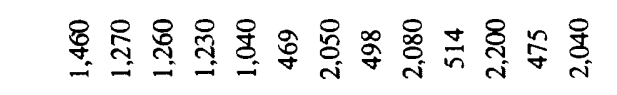 & 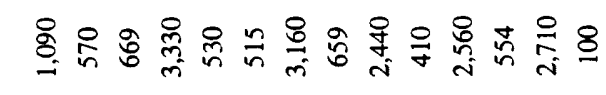 \\
\hline 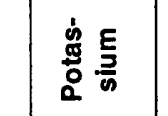 & 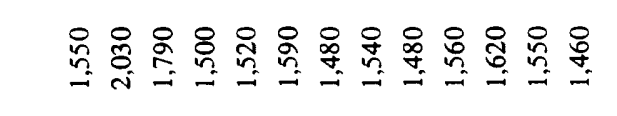 & 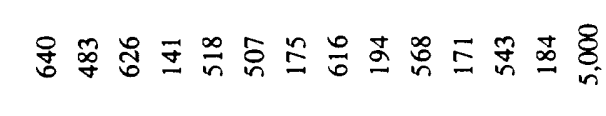 \\
\hline 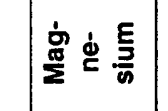 & 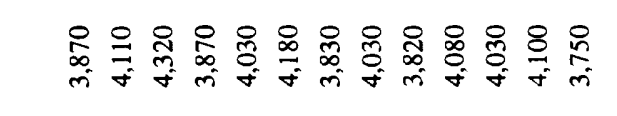 & 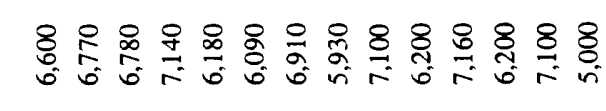 \\
\hline 产焉 & 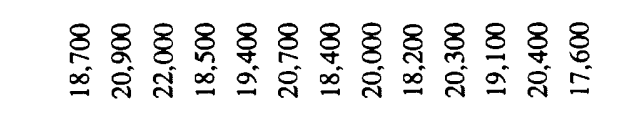 & 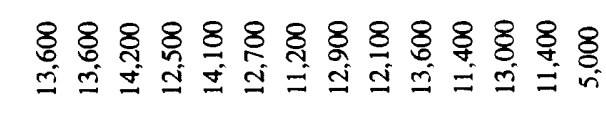 \\
\hline & $\tilde{\dot{\sigma}} \vec{\Xi} \overrightarrow{0} \overrightarrow{0}$ & 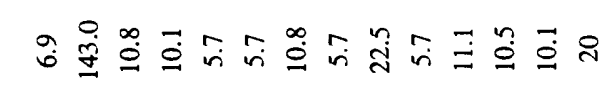 \\
\hline 产 & 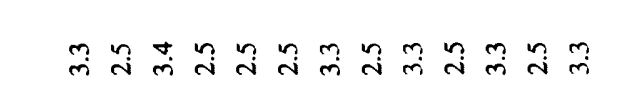 & 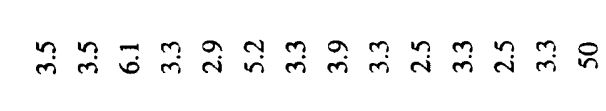 \\
\hline & ڤ & $\vec{\infty}$ సే \\
\hline & 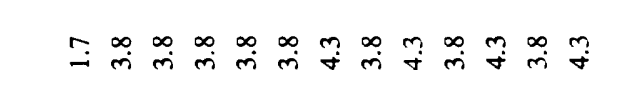 & 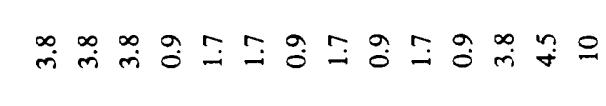 \\
\hline 虽焉 & 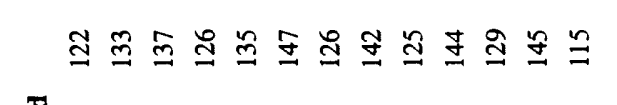 & 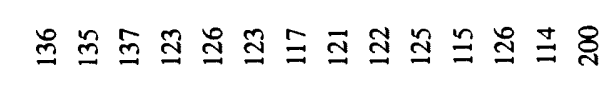 \\
\hline & 童 & 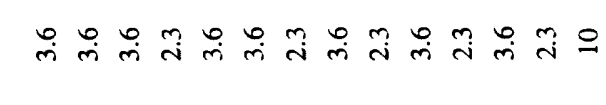 \\
\hline 产高 & 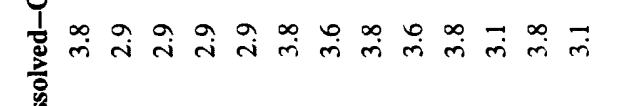 & จे \\
\hline & 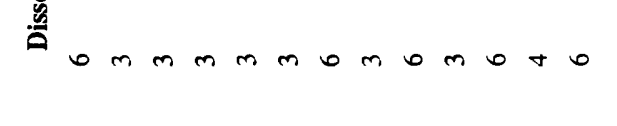 & mmrommomomomo \\
\hline 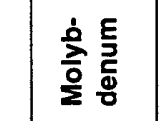 & & 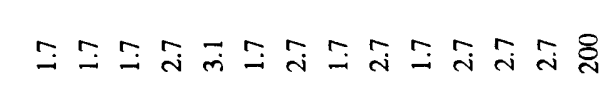 \\
\hline & 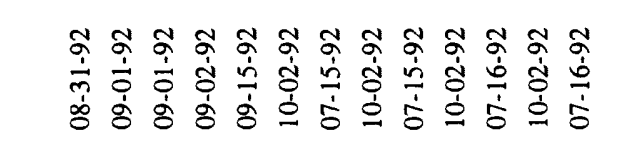 & 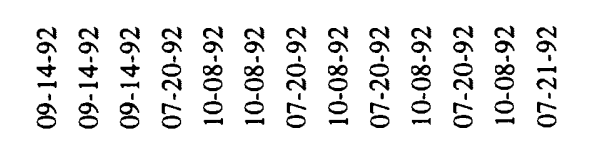 \\
\hline 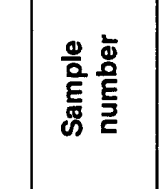 & 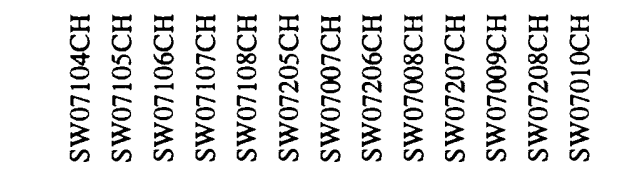 & 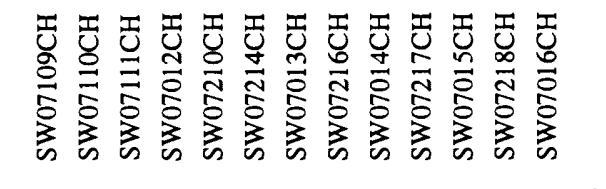 \\
\hline 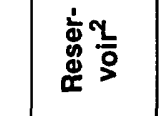 & 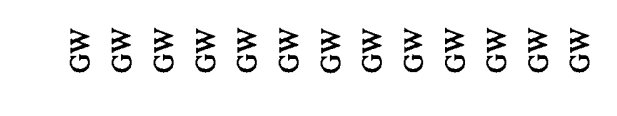 & 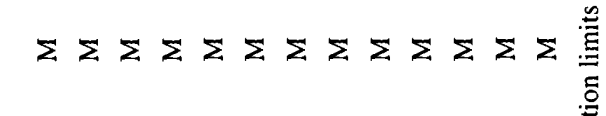 \\
\hline 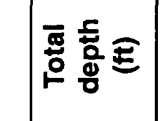 & 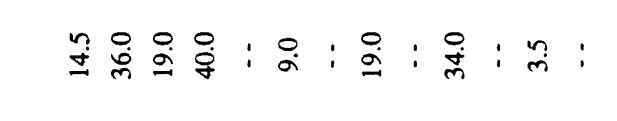 & 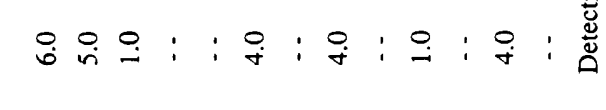 \\
\hline $\mid$ & 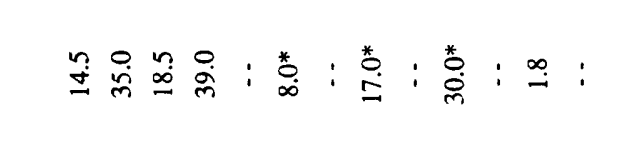 & 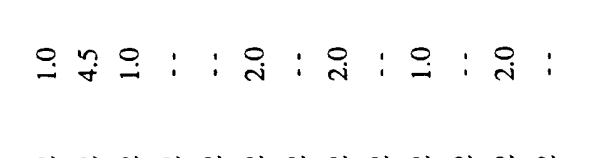 \\
\hline 童 & 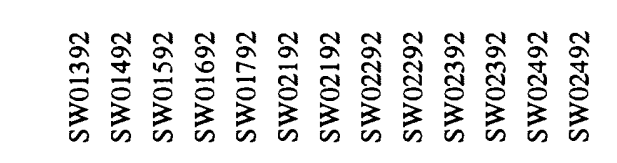 & 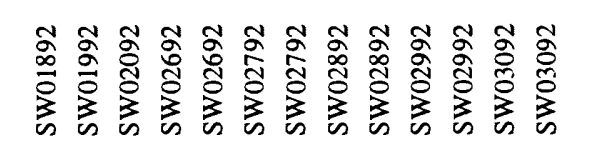 \\
\hline
\end{tabular}




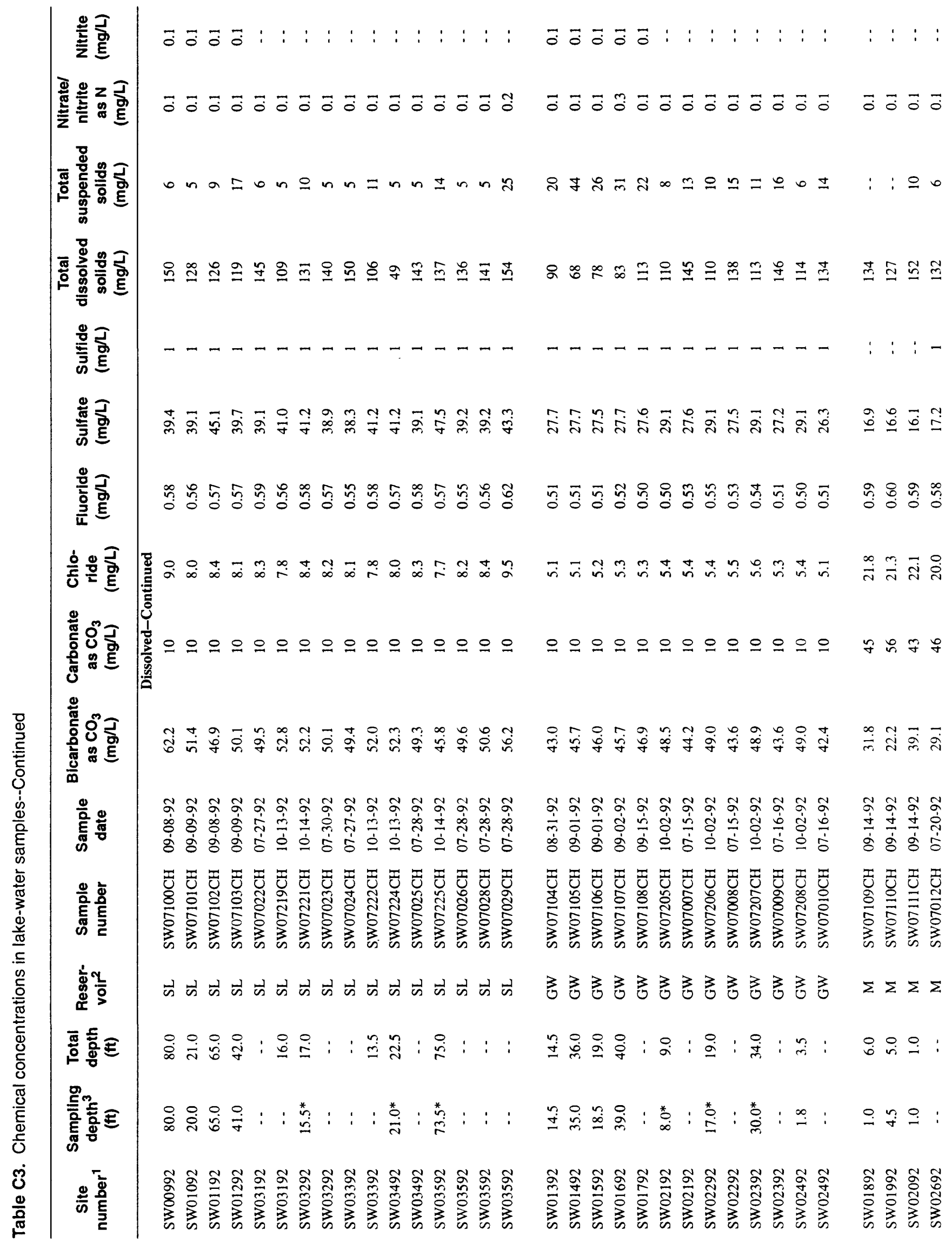

66 Characterization of Selected Radionuclides in Sediment and Surface Water in Standley Lake, Great Western Reservoir, and Mower Reservoir, Jefferson County, Colorado, 1992 

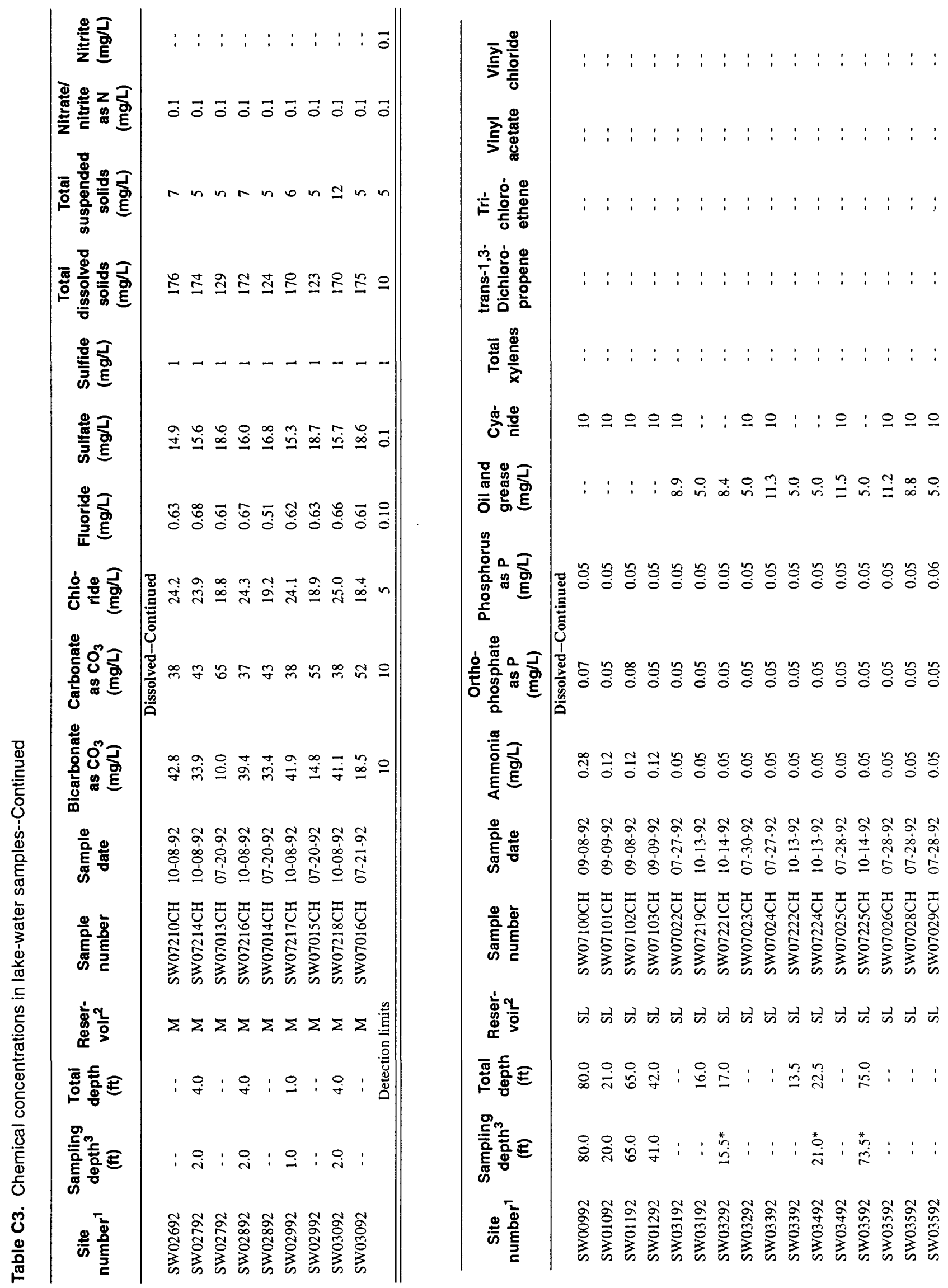


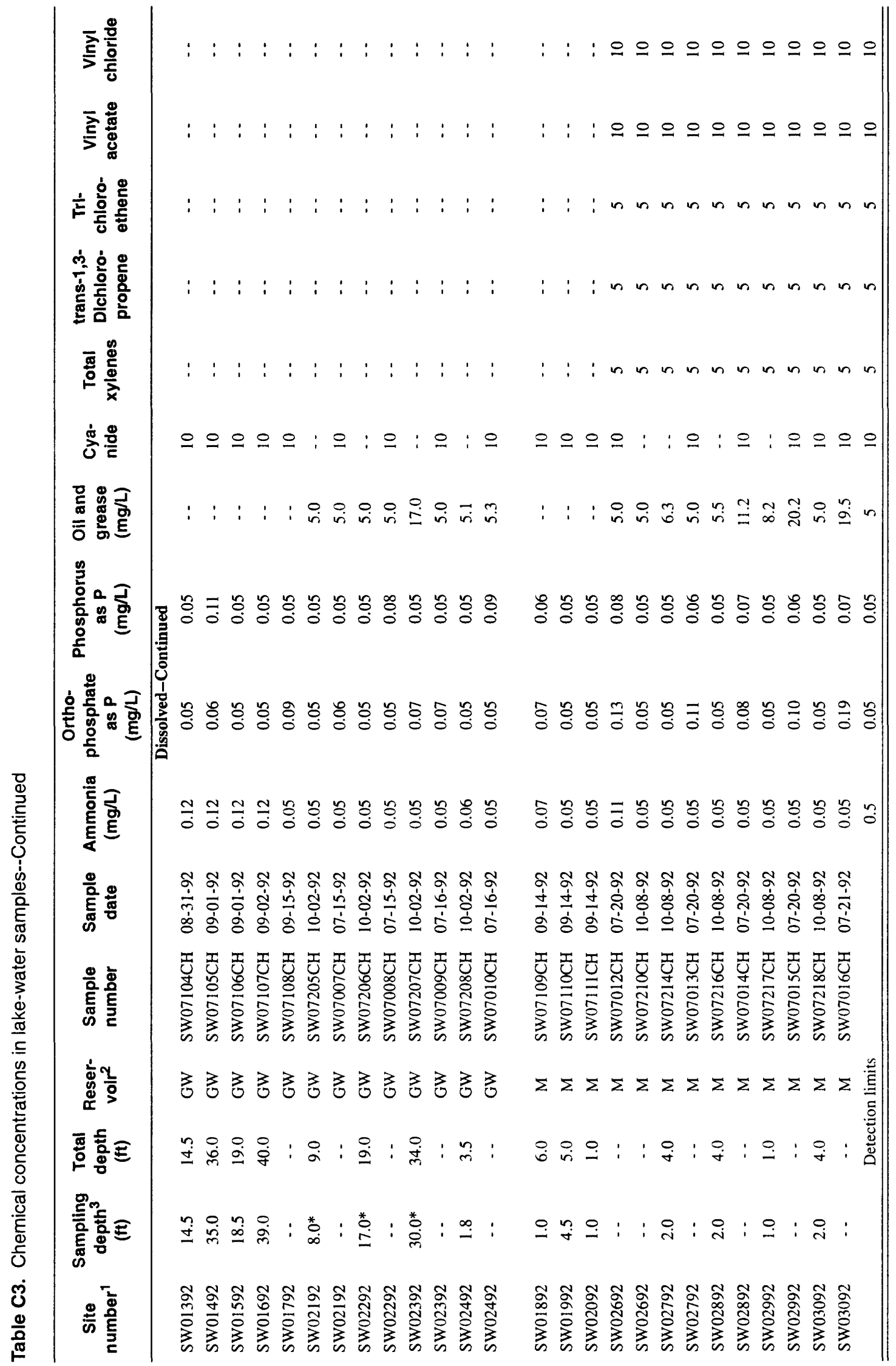

68 Characterization of Selected Radionuclides in Sediment and Surface Water in Standley Lake, Great Western Reservoir, and Mower Reservoir, Jefferson County, Colorado, 1992 
竞要

啇:

畓

善息

$\underline{\underline{\underline{\delta}}}$

客京

产

它量

远

悹要

咅量

离管

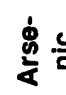

高高

䋰焉

善递

高

寗瓷

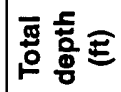

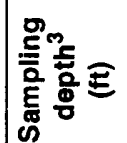

紊毫

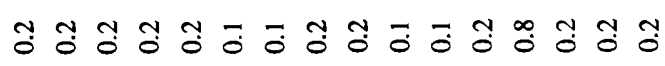

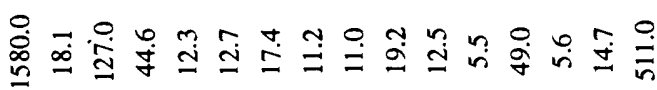

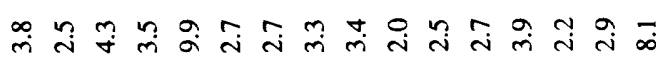

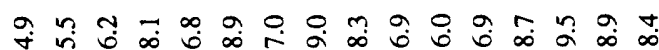

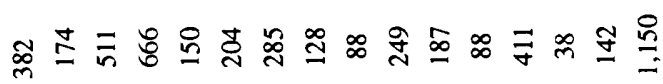

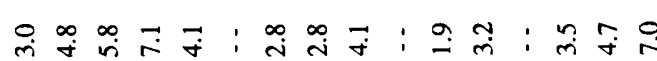

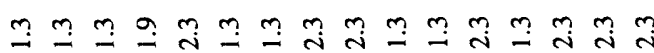

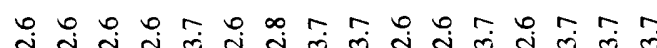

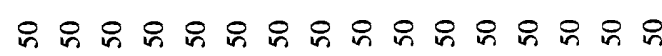

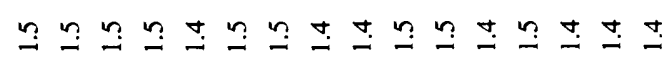

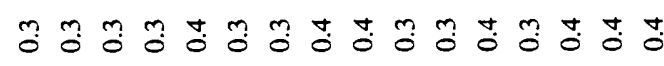

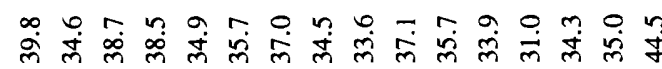
要



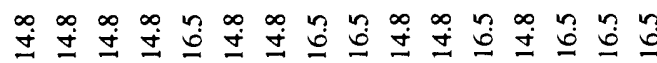

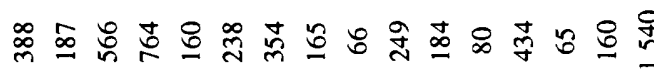

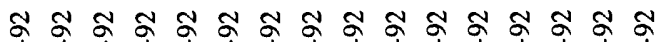

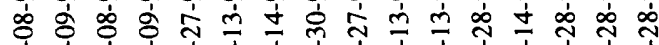

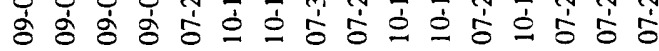

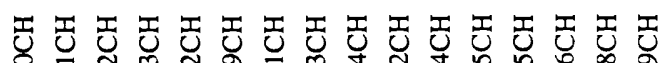
ช

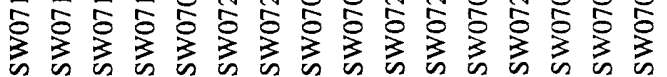

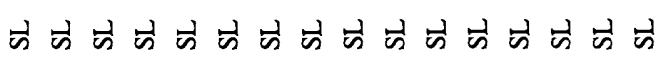

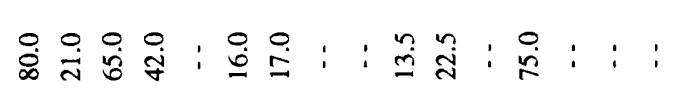

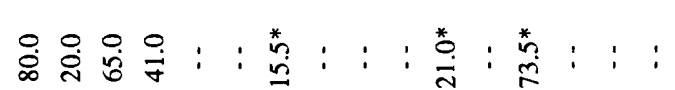

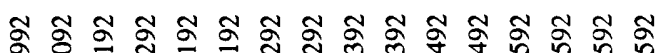

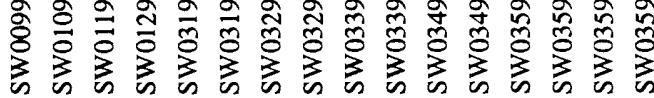

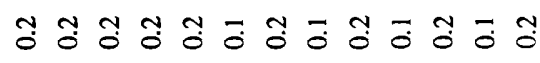

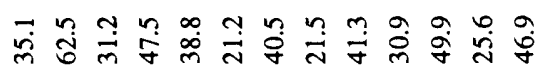

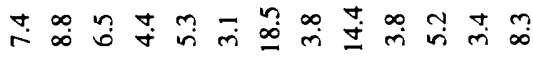

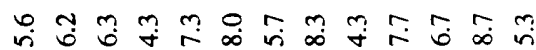

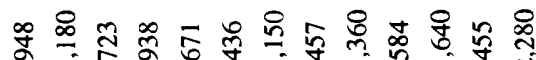

อำ

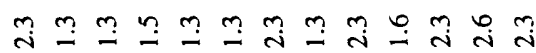

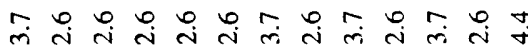

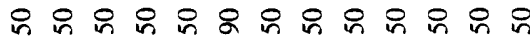

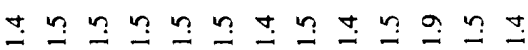

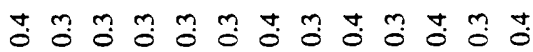

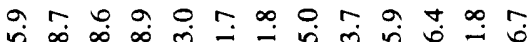

Ұे

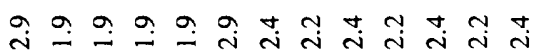

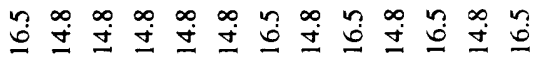

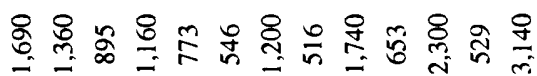

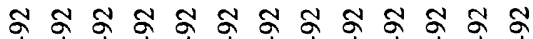

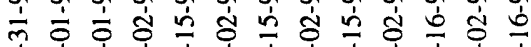

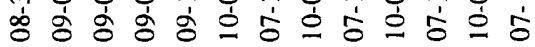

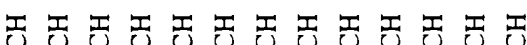
을

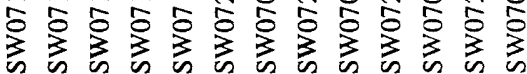

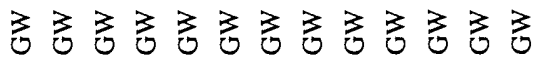

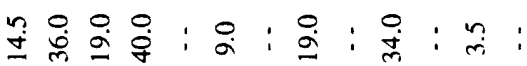

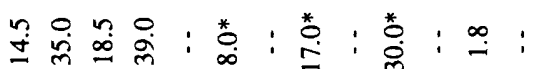

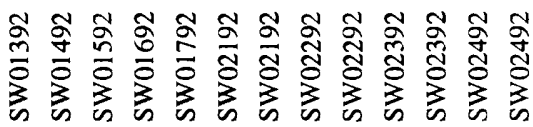

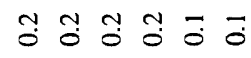

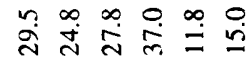

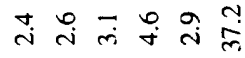

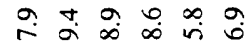

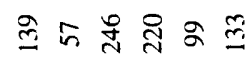

ㅇํㅁำ 29

3. 929

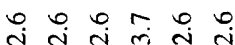

으요용요 용

ำำำ

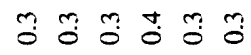

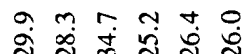

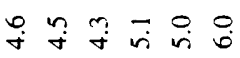

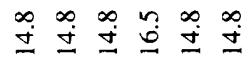

증유요용

สูก สสำ

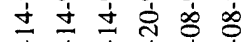
के के के

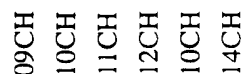

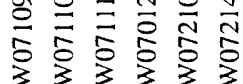

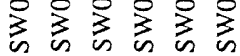

$\Sigma \Sigma \Sigma \Sigma \Sigma \Sigma$

웅우운: : 웅

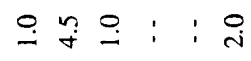

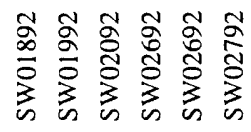




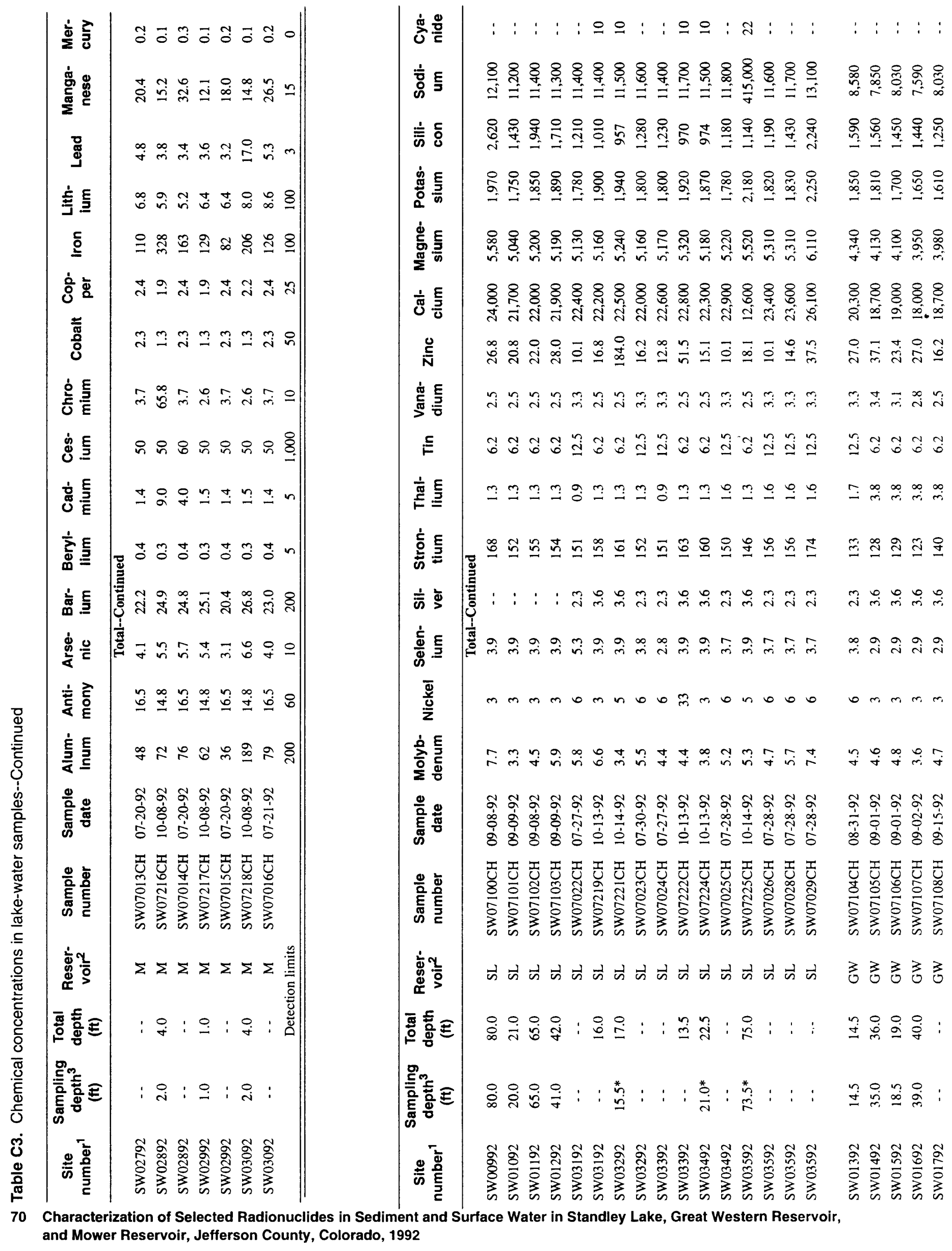




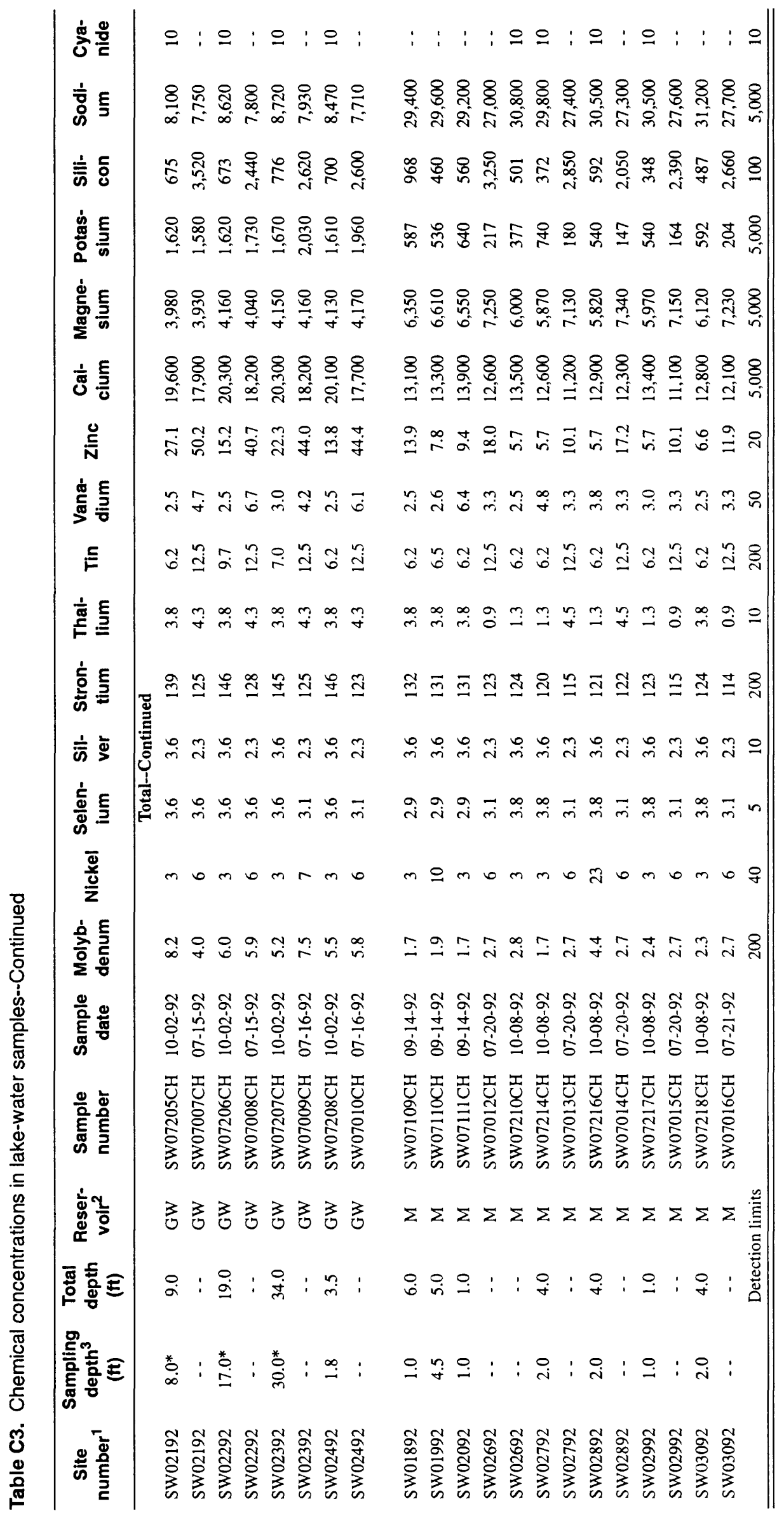




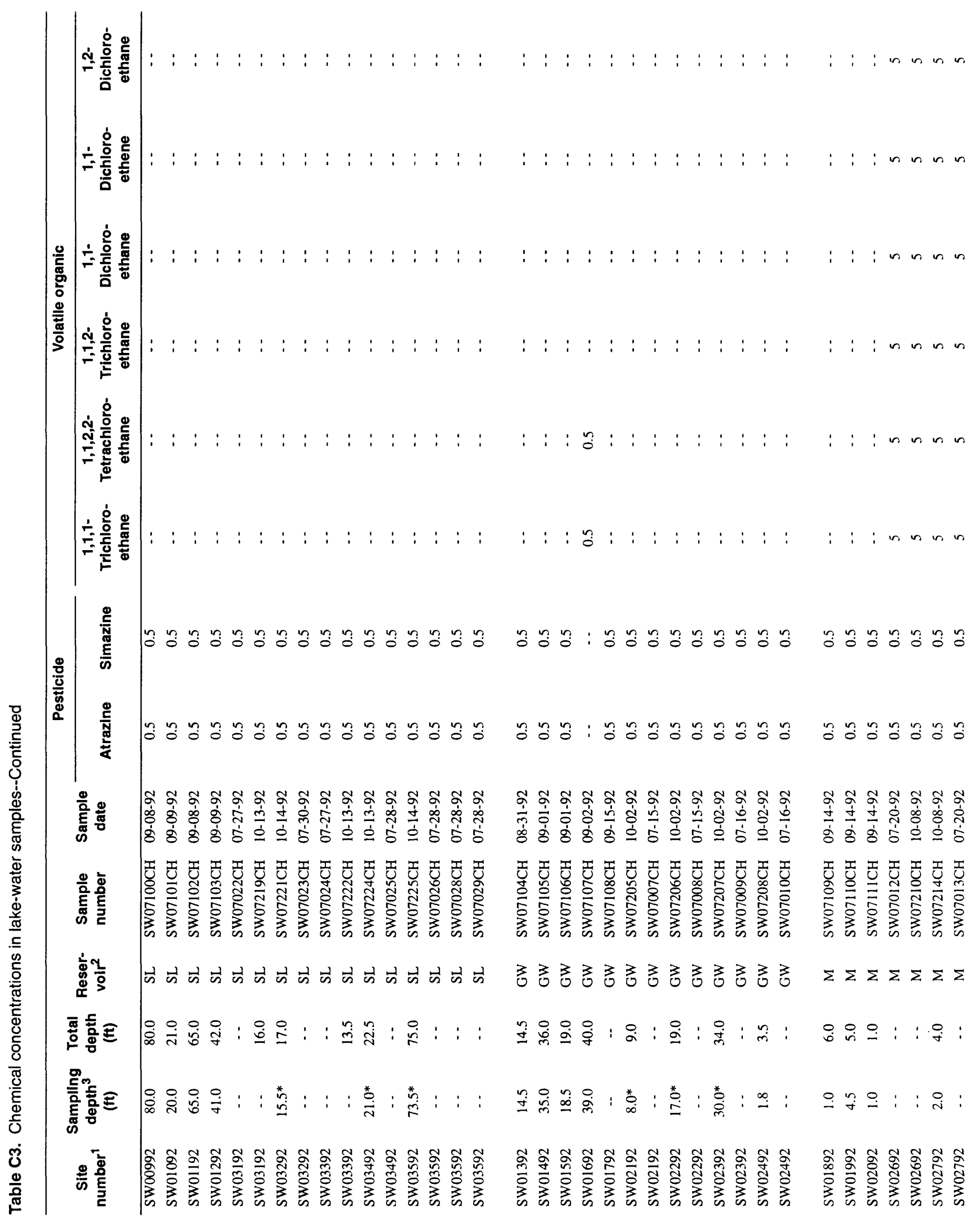

72 Characterization of Selected Radionuclides in Sediment and Surface Water in Standley Lake, Great Western Reservoir, and Mower Reservoir, Jefferson County, Colorado, 1992 

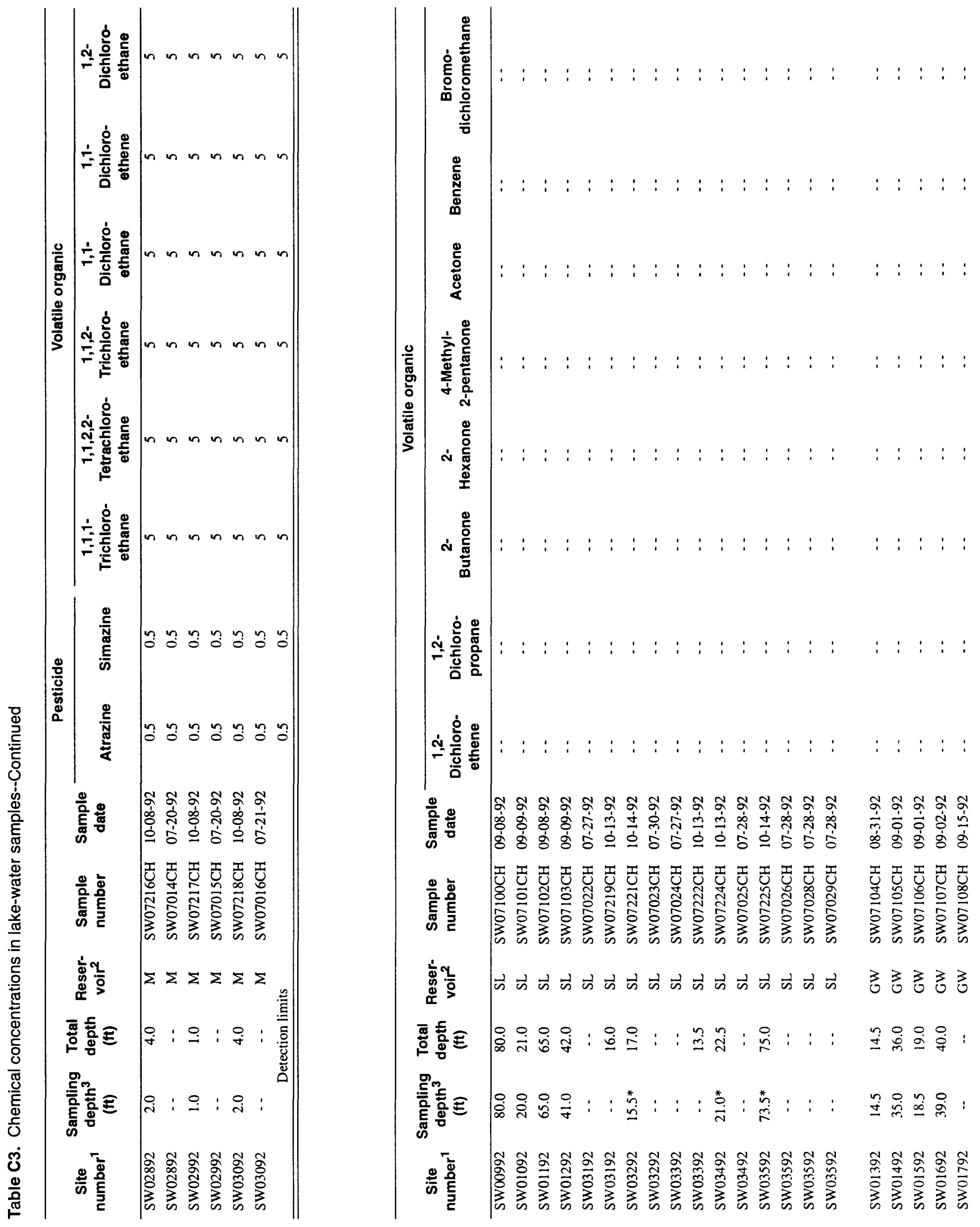

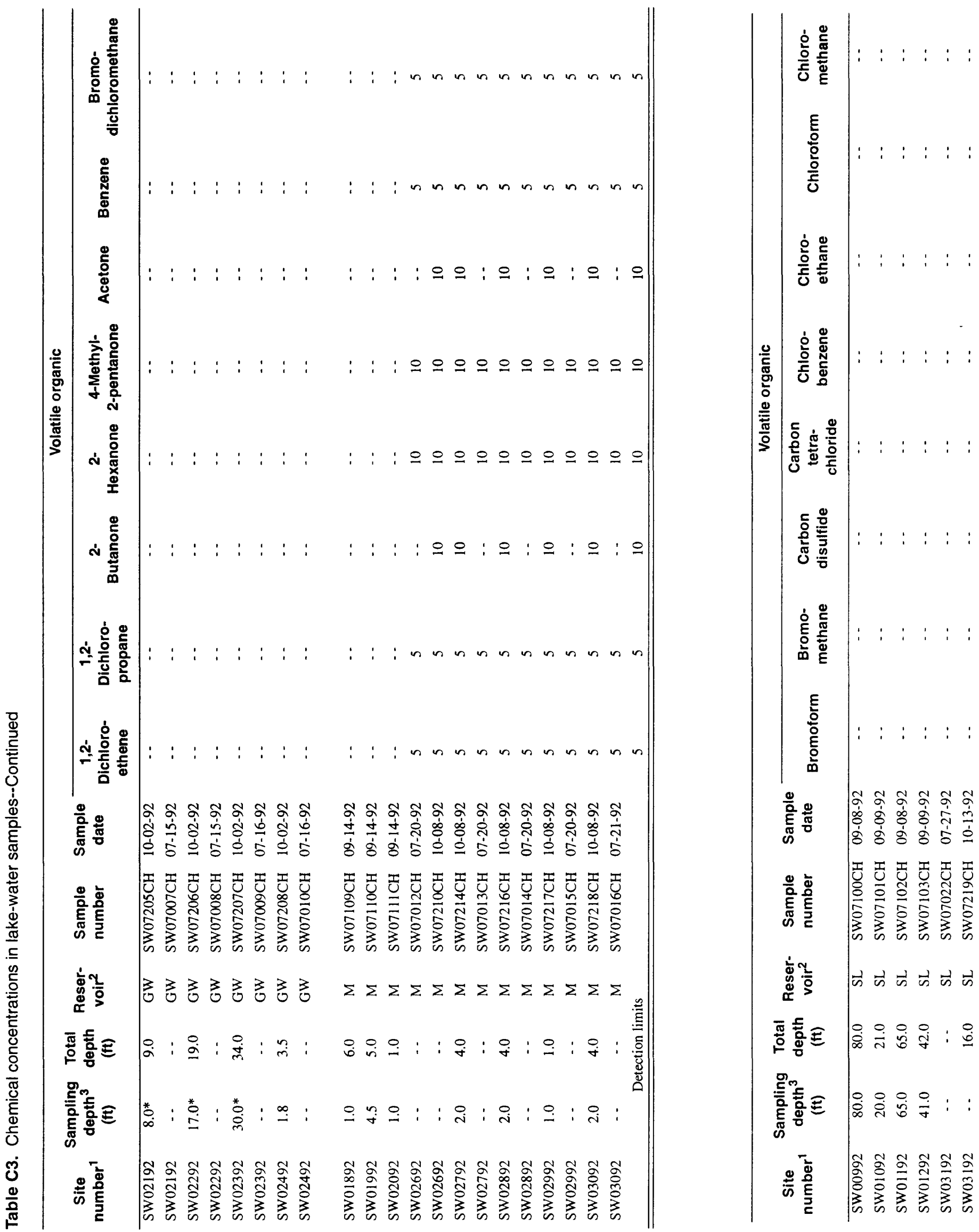

74 Characterization of Selected Radionuclides in Sediment and Surface Water in Standley Lake, Great Western Reservoir, and Mower Reservoir, Jefferson County, Colorado, 1992 


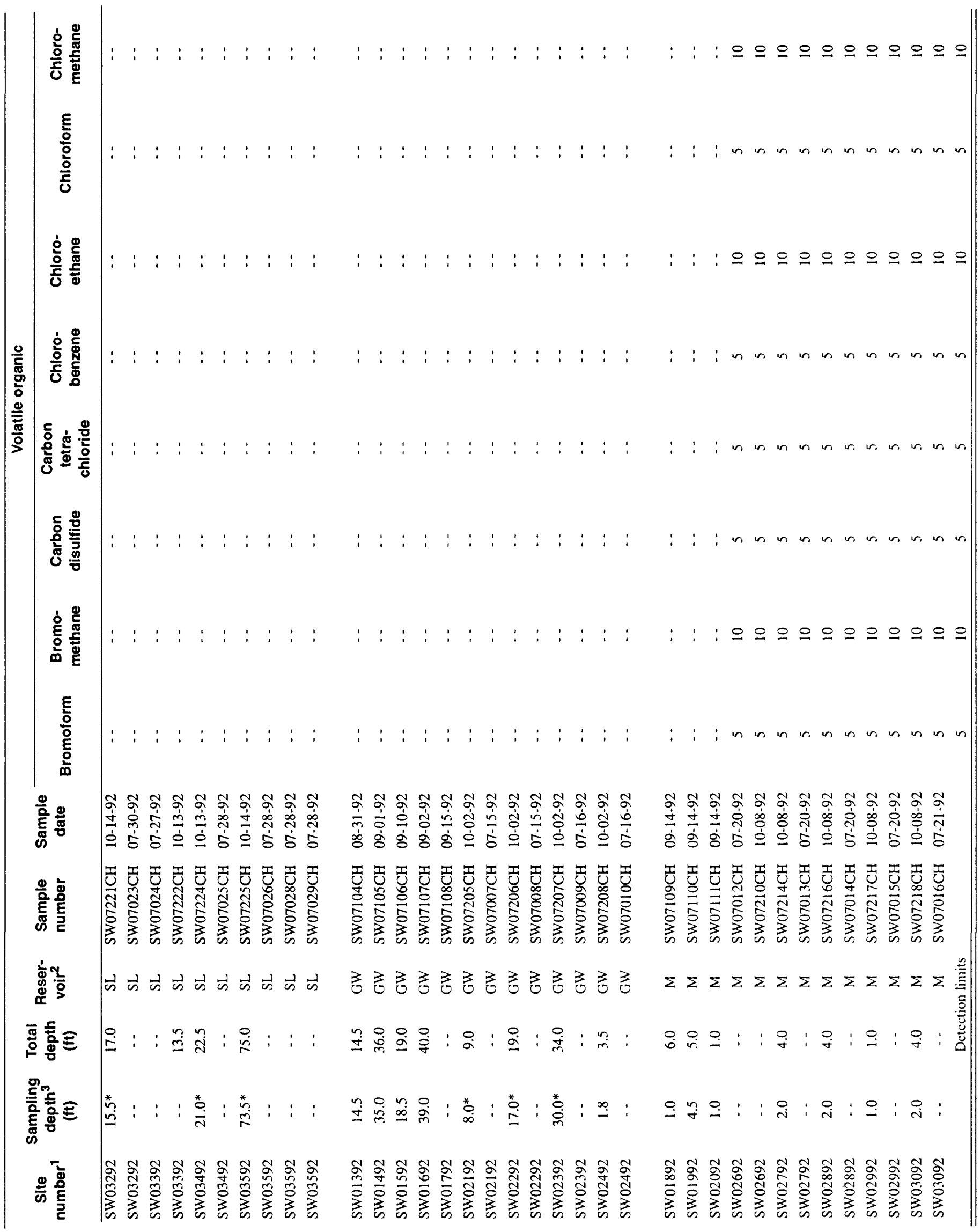




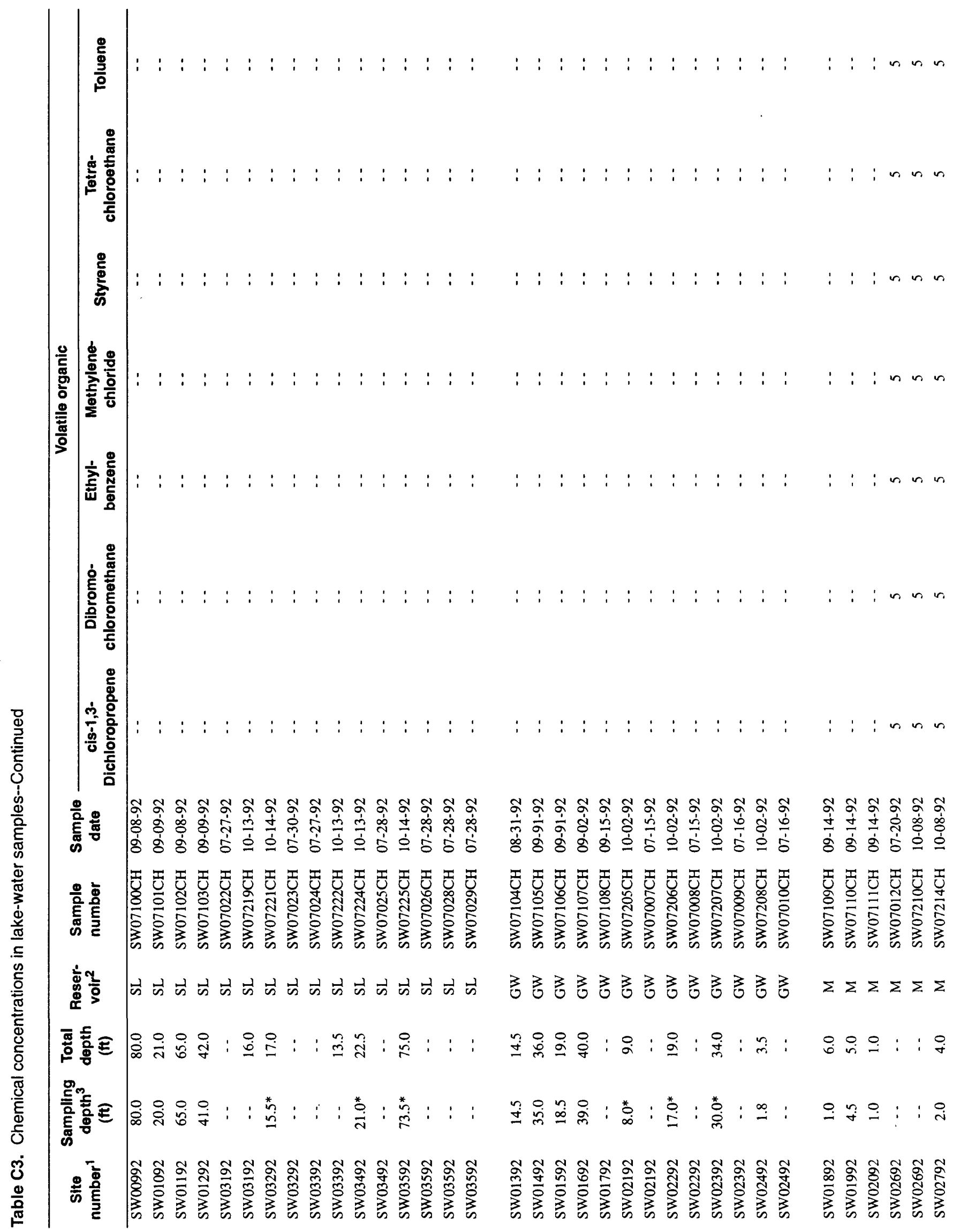




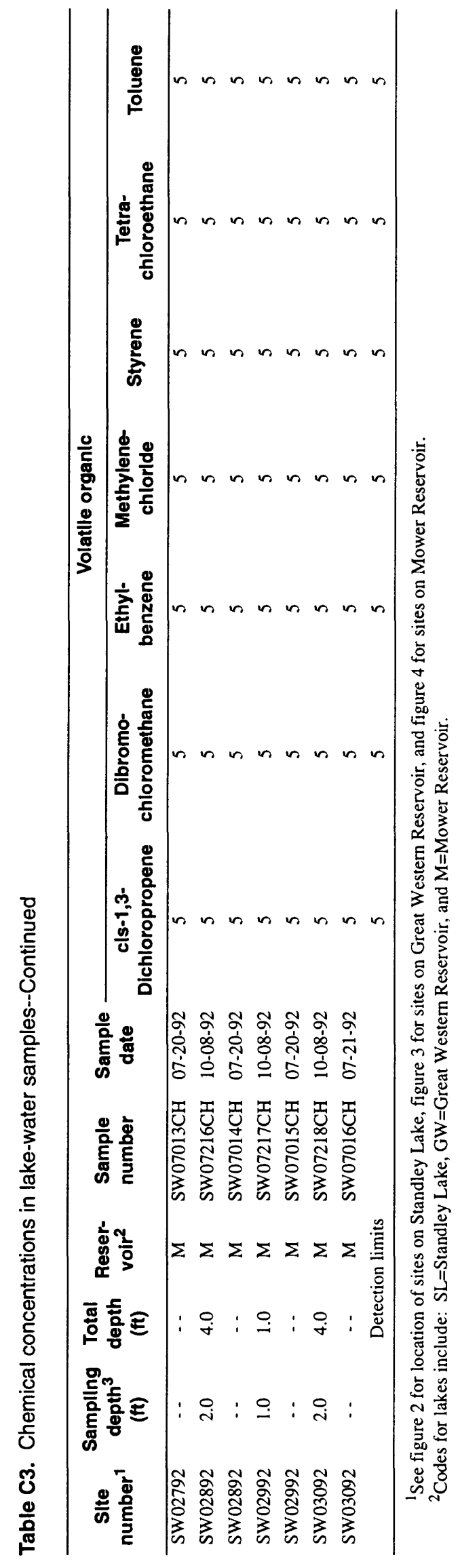

